\title{
Monitoring the Migrations of Wild Snake River Spring/Summer Chinook Salmon Juveniles, 2007-2008
}

\author{
Stephen Achord, Benjamin P. Sandford, Eric E. Hockersmith, Matthew G. Nesbit, \\ Nathan D. Dumdei, Jesse L. Lamb, Kenneth W. McIntyre, Neil N. Paasch, \\ and John G. Williams
}

\author{
Report of research by \\ Fish Ecology Division \\ Northwest Fisheries Science Center \\ National Marine Fisheries Service \\ National Oceanic and Atmospheric Administration \\ 2725 Montlake Boulevard East \\ Seattle, Washington 98112-2097 \\ for \\ Division of Fish and Wildlife \\ Bonneville Power Administration \\ U.S. Department of Energy \\ P.O. Box 3621 \\ Portland, Oregon 97208-3621 \\ Project 1991-028-00, Contract No. 00031849
}

Report covers the period from mid-July 2007 to mid-July 2008

May 2009 


\section{EXECUTIVE SUMMARY}

This report provides results from an ongoing project to monitor the migration behavior and survival of wild juvenile spring/summer Chinook salmon in the Snake River Basin. Data reported is from detections of PIT tagged fish during late summer 2007 through mid-2008. Fish were tagged in summer 2007 by the National Marine Fisheries Service (NMFS) in Idaho and by the Oregon Department of Fish and Wildlife (ODFW) in Oregon. Our analyses include migration behavior and estimated survival of fish at instream PIT-tag monitors and arrival timing and estimated survival to Lower Granite Dam. Principal results from tagging and interrogation during 2007-2008 are listed below:

1) In July and August 2007, we PIT tagged and released 7,390 wild Chinook salmon parr in 12 Idaho streams or sample areas.

2) Overall observed mortality from collection, handling, tagging, and after a 24-hour holding period was $1.4 \%$.

3) Of the 2,524 Chinook salmon parr PIT tagged and released in Valley Creek in summer 2007, 218 (8.6\%) were detected at two instream PIT-tag monitoring systems in lower Valley Creek from late summer 2007 to the following spring 2008. Of these, $71.6 \%$ were detected in late summer/fall, $11.9 \%$ in winter, and $16.5 \%$ in spring. Estimated parr-to-smolt survival to Lower Granite Dam was 15.5\% for the late summer/fall group, $48.0 \%$ for the winter group, and $58.5 \%$ for the spring group. Based on detections at downstream dams, the overall efficiency of $\mathrm{VC} 1$ (upper) or VC2 (lower) Valley Creek monitors for detecting these fish was 21.1\%. Using this VC1 or VC2 efficiency, an estimated $40.8 \%$ of all summer-tagged parr survived to move out of Valley Creek, and their estimated survival from that point to Lower Granite Dam was 26.5\%. Overall estimated parr-to-smolt survival for all summertagged parr from this stream at the dam was $12.1 \%$. Development and improvement of instream PIT-tag monitoring systems continued throughout 2007 and 2008.

4) Testing of PIT-tag antennas in lower Big Creek during 2007-2008 showed these antennas (and anchoring method) are not adequate to withstand high spring flows in this drainage. Future plans involve removing these antennas before high spring flows. 
5) At Little Goose Dam in 2008, length and/or weight were taken on 505 recaptured fish from 12 Idaho stream populations. Fish had grown an average of $40.1 \mathrm{~mm}$ in length and $10.6 \mathrm{~g}$ in weight over an average of $288 \mathrm{~d}$. Their mean condition factor declined from 1.25 at release (parr) to 1.05 at recapture (smolt).

6) Mean release lengths for detected fish were significantly larger than for fish not detected the following spring and summer $(P<0.0001)$.

7) Fish that migrated through Lower Granite Dam in April and May were significantly larger at release than fish that migrated after May $(P<0.0001)$ (only 12 fish migrated after May).

8) In 2008, peak detections at Lower Granite Dam of parr tagged during summer 2007 (from the 12 stream populations in Idaho and 4 streams in Oregon) occurred during moderate flows of $87.5 \mathrm{kcfs}$ on 7 May and high flows of $197.3 \mathrm{kcfs}$ on 20 May. The 10th, 50th, and 90th percentile passage occurred on 30 April, 11 May, and 23 May, respectively.

9) In 2007-2008, estimated parr-to-smolt survival to Lower Granite Dam for Idaho and Oregon streams (combined) averaged 19.4\% (range 6.2-38.4\% depending on stream of origin). In Idaho streams the estimated parr-to-smolt survival averaged $21.0 \%$. This survival was the second highest since 1993 for Idaho streams. Relative parr densities were lower in $2007\left(2.4 \mathrm{parr} / 100 \mathrm{~m}^{2}\right)$ than in all previous years since 2000 .

In 2008, we observed low-to-moderate flows prior to mid-May and relatively cold weather conditions throughout the spring migration season. These conditions moved half of the fish through Lower Granite Dam prior to mid-May; then high flows moved 50 to $90 \%$ of the fish through the dam in only 12 days. Clearly, complex interrelationships of several factors drive the annual migrational timing of the stocks. 


\section{CONTENTS}

EXECUTIVE SUMMARY ….......................................................................... ii

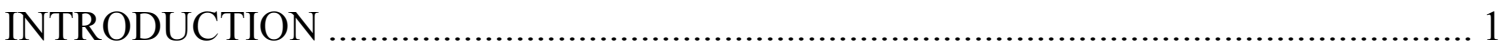

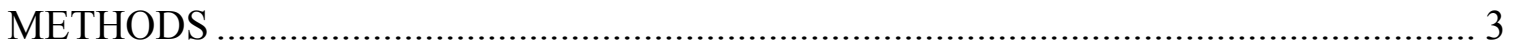

Fish Collection and Tagging ................................................................... 3

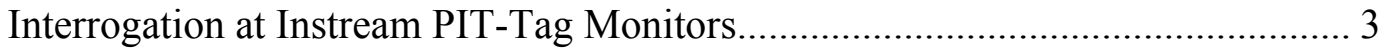

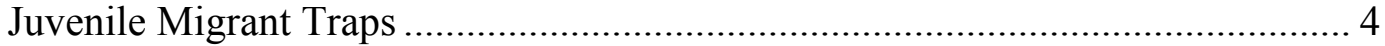

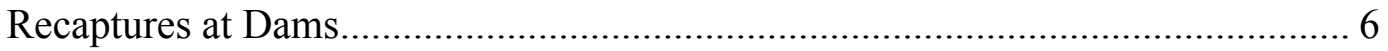

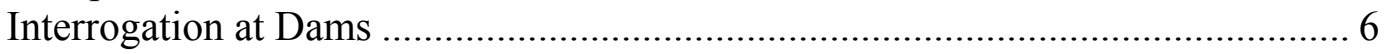

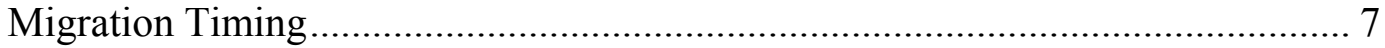

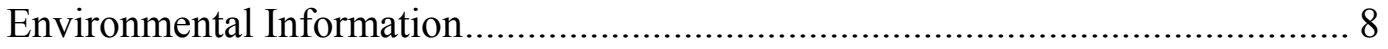

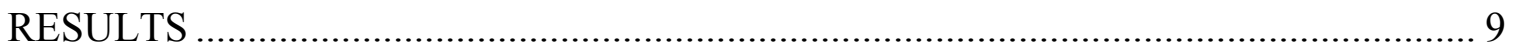

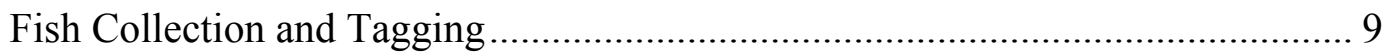

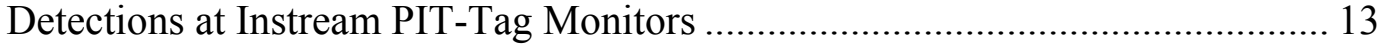

Recaptures at Traps and Dams....................................................................... 14

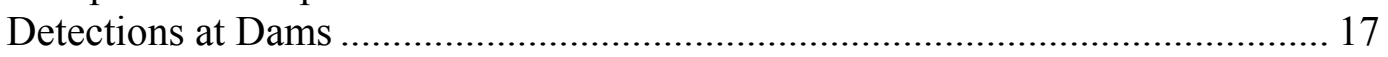

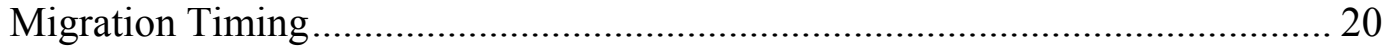

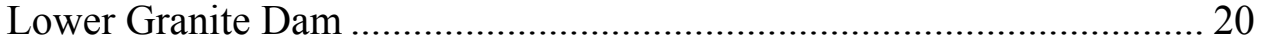

Comparison with Flows ......................................................................... 23

Environmental Information........................................................................ 25

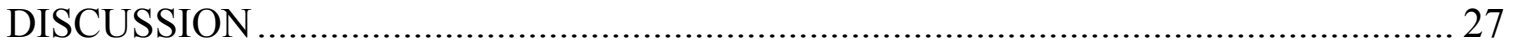

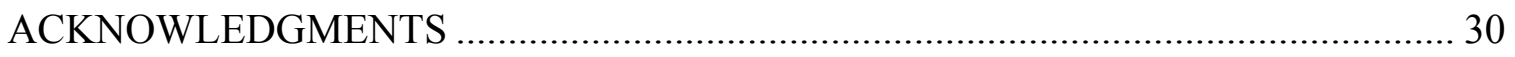

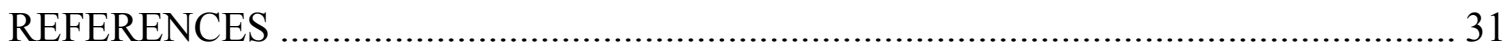

APPENDIX: Data Tables and Figures.................................................................. 35 


\section{INTRODUCTION}

This report provides information on PIT-tagging of wild Chinook salmon parr in Idaho in 2007 and the subsequent monitoring of these fish and similarly tagged fish from Oregon. We report here on the estimated survival and timing of these Chinook salmon juveniles at Lower Granite Dam as well as interrogation data at several other sites throughout the Snake and Columbia River system. This research continues studies that began under Bonneville Power Administration (BPA) funding in 1991. Results from previous study years were reported by Achord et al. (1994-1995a,b; 1996a; 1997-1998; 2000-2001a,b; 2002-2008).

Goals of this ongoing study are to: 1) characterize the migration timing and estimate parr-to-smolt survival of different stocks of wild Snake River spring/summer Chinook salmon smolts at Lower Granite Dam, 2) determine whether consistent migration patterns are apparent, 3) determine what environmental factors influence these patterns, and 4) characterize the migrational behavior and estimate survival of different wild juvenile fish stocks as they migrate from their natal rearing areas.

This study provides critical information for recovery planning and ultimately recovery for these wild fish stocks, which are listed as threatened under the U.S. Endangered Species Act.

During 2007-2008, we collected water temperature, dissolved oxygen, specific conductance, turbidity, water depth, and $\mathrm{pH}$ data at six monitoring stations in the Salmon River Basin, Idaho for the Baseline Environmental Monitoring Program. These environmental data can be compared with parr/smolt migration, survival, and timing data to help to discern whether patterns or characteristic relationships exist that may help in recovery planning for threatened stocks. 


\section{METHODS}

\section{Fish Collection and Tagging}

The Oregon Department of Fish and Wildlife (ODFW) PIT tagged wild Chinook salmon parr in the Grande Ronde and Imnaha River drainages in northeast Oregon in 2007. All tagging, detection, and timing information for fish from these streams in 2007-2008 will be reported by ODFW. However, with ODFW's concurrence, we report here the timing and overall estimated survival at Lower Granite Dam of summer-tagged fish from these Oregon streams.

National Marine Fisheries Service (NMFS) personnel tagged fish in Idaho streams during 2007 using the safe handling methods developed for the wild fish study. These handling methods are detailed in Matthews et al. (1990) and in previous reports from this study (Achord et al. 1994; 1995a,b; 2003; 2004).

In 2007, NMFS personnel were unable to PIT tag wild fish from Chamberlain and W. F. Chamberlain Creeks and South Fork Salmon and Secesh Rivers due to extensive forest fires and closures in these areas.

\section{Interrogation at Instream PIT-Tag Monitors}

Until recently, the opportunities to monitor migrating PIT-tagged wild juvenile fish were limited to a few instream or river traps (these traps require operators and are not passive monitoring sites), the juvenile fish bypass systems at dams, and a surface pair trawl detection system deployed in the Columbia River estuary (rkm 75). In an effort to detect fish closer to tagging sites, we began development of instream PIT-tag monitoring systems in Valley Creek in 2002. We placed these systems at two sites located $1.2 \mathrm{~km}$ apart. Development of instream monitoring systems continued throughout 2003-2007, and details about the equipment used described in Achord et al. (2004, 2005). Briefly, both systems were set up to automatically interrogate, store, and transmit data to the PIT-Tag Information System (PTAGIS), operated by the Pacific States Marine Fisheries Commission (PTAGIS 1996).

In summer 2007, NMFS transitioned from using the TX1411-ST 12-mm PIT tag to the new TX1411-SST 12-mm PIT tag for this study. The main reason for this change was extended detection range (maximum about $43 \mathrm{~cm}$ ) of the SST tag compared to the $\mathrm{ST}$ tag (maximum range about $20 \mathrm{~cm}$ ). From 1 August 2007 through the first week of 
September 2007, a single instream ("hybrid") antenna at each site was operated in Valley Creek, as in previous years. Starting the second week of September 2007, MUX-type transceivers were installed at both Valley Creek monitoring sites and two "pass-by" antennas were attached to the substrate at both monitoring sites. These were "speed-bump" type antennas constructed of $12.7-\mathrm{mm}$ polyethylene (base $60 \mathrm{~cm}$; height $17 \mathrm{~cm}$; length $3 \mathrm{~m}$ ) and placed end-to-end (with a gap in between). One of the antennas at the upstream monitoring site failed after about 2 months of operation and was not replaced until mid-2008. In addition, as development of this system continued throughout 2007-2008; the monitoring systems operated intermittently throughout the period.

In summer 2006, NMFS personnel installed two instream PIT tag monitoring sites in lower Big Creek, approximately $10 \mathrm{~km}$ upstream from the streams' mouth, on the University of Idaho's Taylor Ranch Field Station property. Achord et al. (2008) describe the details and operation at these monitoring sites from August to December 2006. December 2006 to mid-2008 was spent developing new more durable "pass-by" type antennas that could be fitted (with special anchoring stakes) within the substrate of the stream. After testing these antennas in winter and spring 2007-2008, it was decided that they must be removed from the stream before high spring flows.

Here we report data collected at Valley Creek from August 2007 through June 2008.

\section{Juvenile Migrant Traps}

Some fish PIT tagged as parr in natal rearing areas are subsequently collected at migrant traps (Figure 1). During fall 2007 and spring 2008, juvenile migrant fish traps were operated at Knox Bridge on the South Fork of the Salmon River, on Lake Creek, the Secesh River near Chinook Campground and near the stream mouth, on Marsh Creek, in lower Big Creek at Taylor Ranch, and near the Sawtooth Hatchery on the upper Salmon River. Also during spring 2008, juvenile migrant fish traps were operated on the lower Salmon River near Whitebird, Idaho, and on the Snake River at Lewiston, Idaho. Traps were operated by the Nez Perce Tribe and the Idaho Department of Fish and Game.

Generally, fish at these traps were anesthetized, scanned for PIT tags, and then measured for length and weight. Some of these fish were also PIT tagged at the traps. Upon recovery from the anesthetic, all fish were released back to the streams or rivers. 


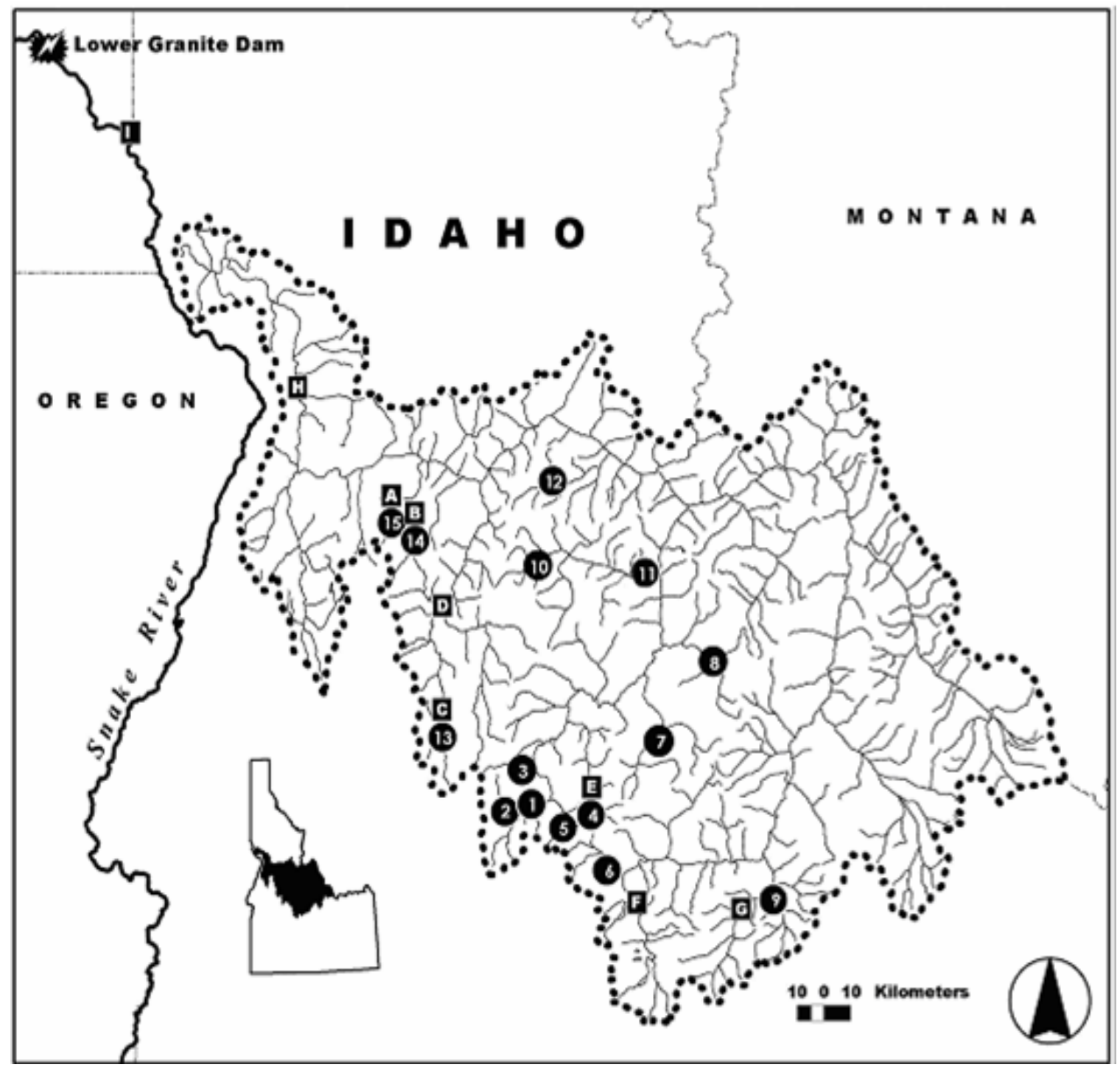

Figure 1. Wild spring/summer Chinook salmon parr were PIT tagged during 2007 in the following stream or sample areas:

1-Bear Valley Creek

2-Elk Creek

3-Sulphur Creek

4-Marsh Creek

5-Cape Horn Creek

6-Valley Creek

7-Loon Creek

8-Camas Creek
9-Herd Creek

10-Big Creek (upper)

11-Big Creek (lower)(and Trap)

12-(not sampled)

13-(not sampled)

14-(not sampled)

15-Lake Creek

Juvenile migrant fish traps shown above are as follows:

A-Lake Creek Trap

B-Secesh River Trap

C-South Fork Salmon River Trap

D-Lower Secesh River Trap

E-Marsh Creek Trap
F-Sawtooth Trap

G-East Fork Salmon River Trap

H-Salmon River Trap

I-Snake River Trap 


\section{Recaptures at Dams}

While collecting and PIT tagging fish at the dams for various studies, NMFS and other personnel occasionally encounter wild fish that are already PIT tagged. In such cases, biological data are usually collected from these fish. To increase sample sizes for parr-to-smolt growth information on previously PIT-tagged wild fish, in 2008 we continued efforts begun in 2001 to utilize the PIT-tag separation-by-code system (Downing et al. 2001) at Little Goose Dam. The system was programmed to separate up to a maximum of 100 wild fish from each stream so that we could take length and weight measurements from a sample of fish. All fish that were separated at the dam were handled using water-to-water transfers and other best handling practices. After handling, all tagged and untagged fish were returned to the bypass system for release below the dam.

In addition to length and weight measurements on these wild smolts at Little Goose Dam, a Fulton-type condition factor (CF) was calculated as:

$$
C F=\frac{\text { weight }(\mathrm{g})}{\text { length }(\mathrm{mm})^{3}} \times 10^{5}
$$

Condition factors were calculated for these fish both at release (using release data associated with the PIT tag code) and recapture.

\section{Interrogation at Snake River and Lower Columbia River Dams}

During spring and summer 2008, surviving Chinook salmon PIT tagged as parr in 2007 for this study migrated volitionally downstream through hydroelectric dams on the Snake and Columbia Rivers. Of the eight dams smolts passed on the lower Snake and Columbia Rivers, the following seven were equipped with smolt collection and/or PIT-tag interrogation systems: Lower Granite, Little Goose, Lower Monumental, and Ice Harbor Dams on the Snake River, and McNary, John Day, and Bonneville Dams on the Columbia River.

At these seven dams, all smolts guided from turbine intakes into juvenile bypass systems were electronically monitored for PIT tags with the same (or similar) interrogation systems as those described by Prentice et al. (1990). Dates and times to the nearest second were automatically recorded on a computer as PIT-tagged fish passed each detector. Detection data were transferred to the PTAGIS regional database at designated intervals each day. Tagged fish were also monitored using a surface pair-trawl fitted with a PIT-tag detection antenna and operated in the upper Columbia River estuary $\sim 150 \mathrm{~km}$ downstream from Bonneville Dam (Ledgerwood et al. 2004). 


\section{Migration Timing}

We monitored within-season migration timing at Lower Granite Dam based on daily detection numbers (of all wild PIT-tagged Chinook salmon smolts) expanded relative to estimated daily detection probabilities. Detection probabilities were calculated using the methods of Sandford and Smith (2002) to provide an estimate of the number of PIT-tagged wild spring/summer Chinook salmon smolts that passed the dam each day. These daily totals were then summed to obtain a yearly survival estimate, which we compared to survival estimates from previous years.

Streams where wild parr were tagged for this study varied in temperature, elevation, mean flow, and population size. Therefore, to compare arrival timing at Lower Granite Dam between streams, we used an approach analogous to analysis of variance with multiple comparisons. The bootstrap method of Efron and Tibshirani (1993) was used to calculate estimates of the standard error for each migration timing statistic (i.e., arrival dates of the 10th, 50th (median), and 90th percentiles of the tagged population from each stream or sample area). Then, a "representative" estimate of variance for each statistic was calculated as the median of the standard errors (SEs) for fish from 16 stream populations. This method assumed that timing of passage percentiles had similar distributions among streams. The Student-Newmann-Keuls (SNK) multiple comparison method was used to make comparisons between streams for each statistic $(\alpha=0.05$; Petersen 1985).

We also examined the migration timing of individual populations at Lower Granite Dam over a period of years to determine similarities or differences between years and between populations. We chose populations with 8 or more years of timing data for these analyses. Comparisons of the 10th, 50th, and 90th percentile passage dates were made among 18 streams or sample areas using a two-factor analysis of variance (ANOVA). "Year" was considered a random factor and "stream" a fixed factor. Residuals were visually examined to assess normality. Treatment means were compared using Fisher's least significant difference procedure (Peterson 1985). Statistical significance was set at $\alpha=0.05$. 


\section{Environmental Information}

In 2007-2008, we collected hourly measurements of water temperature, dissolved oxygen, specific conductance, turbidity, water depth, and $\mathrm{pH}$ from the following locations: 1) Marsh Creek, 2) Valley Creek, 3) Sawtooth Hatchery in the upper Salmon River, 4) South Fork of the Salmon River (Knox Bridge), 5) Secesh River, and 6) Big Creek (lower) at Taylor Ranch. All monitoring systems except the system at Valley Creek were close to juvenile migrant fish traps. The water quality monitor at Valley Creek was located near our instream PIT-tag monitoring system (VC2). 


\section{RESULTS}

\section{Fish Collection and Tagging}

From 26 July to 24 August 2007, we collected 8,594 wild Chinook salmon parr in 12 Idaho stream populations (Figure 1) over a distance of about 38 stream kilometers and approximately $354,709 \mathrm{~m}^{2}$ (Table 1; Appendix Table 1). Of these fish, 7,390 were PIT tagged and released back into the streams along with the remaining untagged live fish. Some fish were not tagged because they were previously tagged, of small size, injured, precocious, or excess numbers collected. Numbers of tagged fish released per stream or sample area ranged from 247 in Big Creek (lower) to 2,524 in Valley Creek (Table 1 and Appendix Tables 1 and 2a).

Fork lengths of all collected Chinook salmon parr ranged from 40 to $144 \mathrm{~mm}$ (mean $69.4 \mathrm{~mm}$ ) and weights ranged from 0.7 to $39.7 \mathrm{~g}$ (mean $4.5 \mathrm{~g}$ ). The fork lengths of tagged and released Chinook salmon parr ranged from 55 to $106 \mathrm{~mm}$ (mean $69.8 \mathrm{~mm}$ ) and weights ranged from 1.0 to $18.9 \mathrm{~g}$ (mean $4.4 \mathrm{~g}$; Appendix Table 1). In 2007, collection areas within the streams were further delineated by recording Global Positioning System (GPS) coordinates using Universal Transverse Mercator (UTM) grid (Appendix Table 2b).

Other than Chinook salmon parr, sculpin were the most abundant fish observed during collection operations (Table 2). However, the records of non-target fish do not represent total abundances in the collection areas as we targeted collecting Chinook salmon, not other coincident species. 
Table 1. Summary of collection, PIT tagging, and release of wild Chinook salmon parr with average fork lengths and weights, approximate distances, and estimated areas sampled in streams of Idaho during July and August 2007.

\begin{tabular}{|c|c|c|c|c|c|c|c|c|}
\hline \multirow[b]{2}{*}{ Tagging location } & \multicolumn{2}{|c|}{ Number of fish } & \multicolumn{2}{|c|}{ Average length (mm) } & \multicolumn{2}{|c|}{ Average weight (g) } & \multirow{2}{*}{$\begin{array}{c}\text { Distance: } \\
\text { collection area to } \\
\text { stream mouth }(\mathrm{km})\end{array}$} & \multirow[b]{2}{*}{$\begin{array}{c}\text { Area sampled } \\
\left(\mathrm{m}^{2}\right)\end{array}$} \\
\hline & Collected & $\begin{array}{c}\text { Tagged } \\
\text { and released } \\
\end{array}$ & Collected & Tagged & Collected & Tagged & & \\
\hline Bear Valley Creek & 539 & 514 & 68.9 & 69.0 & 4.2 & 4.2 & $9-11 ; 12-14$ & 43,918 \\
\hline Elk Creek & 850 & 500 & 71.4 & 70.4 & 4.9 & 4.4 & $0-2$ & 16,262 \\
\hline Cape Horn Creek & 681 & 499 & 64.4 & 66.3 & 3.4 & 3.5 & $0-2$ & 15,825 \\
\hline Valley Creek & 2,923 & 2,524 & 69.0 & 70.0 & 4.6 & 4.5 & $4-10 ; 12$ & 82,950 \\
\hline Camas Creek & 525 & 507 & 69.0 & 69.0 & 4.2 & 4.3 & $22-25$ & 22,602 \\
\hline Herd Creek & 331 & 320 & 79.1 & 79.0 & 6.9 & 6.9 & $1-4$ & 21,418 \\
\hline Big Creek (upper) & 647 & 628 & 70.3 & 70.3 & 4.5 & 4.5 & $59-62$ & 32,862 \\
\hline Big Creek (lower) & 268 & 247 & 75.7 & 75.9 & 5.3 & 5.4 & $8-12$ & 29,164 \\
\hline Loon Creek & 293 & 276 & 68.4 & 69.0 & 3.7 & 3.8 & $34-37$ & 24,647 \\
\hline Marsh Creek & 554 & 499 & 70.5 & 70.8 & 4.4 & 4.5 & $12-14$ & 17,158 \\
\hline Sulphur Creek & 396 & 375 & 67.5 & 68.0 & 4.3 & 4.2 & $4-8$ & 34,915 \\
\hline Lake Creek & 587 & 501 & 66.1 & 65.1 & 4.2 & 3.9 & $1-2$ & 12,988 \\
\hline Totals or averages & 8,594 & 7,390 & 69.4 & 69.8 & 4.5 & 4.4 & 38 & 354,709 \\
\hline
\end{tabular}


Table 2. Summary of species other than Chinook salmon parr observed during collection operations in Idaho in July and August 2007. Numbers of steelhead in parentheses were PIT tagged for the Idaho Department of Fish and Game.

\begin{tabular}{|c|c|c|c|c|c|c|}
\hline Streams & Steelhead & $\begin{array}{c}\text { Tagged } \\
\text { Steelhead } \\
\end{array}$ & $\begin{array}{c}\text { Unidentified } \\
\text { Fry } \\
\end{array}$ & $\begin{array}{c}\text { Brook } \\
\text { trout }\end{array}$ & $\begin{array}{c}\text { Cutthroat } \\
\text { trout }\end{array}$ & $\begin{array}{c}\text { Bull } \\
\text { Trout }\end{array}$ \\
\hline Bear Valley Creek & 434 & $(0)$ & 602 & 479 & 0 & 3 \\
\hline Elk Creek & 92 & (0) & 84 & 105 & 0 & 3 \\
\hline Cape Horn Creek & 38 & (0) & 258 & 89 & 0 & 3 \\
\hline Valley Creek & 772 & (0) & 2,500 & 506 & 0 & 7 \\
\hline Camas Creek & 354 & (0) & 997 & 1 & 3 & 7 \\
\hline Herd Creek & 554 & (0) & 325 & 0 & 0 & 1 \\
\hline Big Creek (upper) & 405 & (308) & 322 & 315 & 0 & 15 \\
\hline Big Creek (lower) & 246 & (123) & 475 & 0 & 9 & 2 \\
\hline Loon Creek & 258 & (0) & 1,143 & 1 & 0 & 3 \\
\hline Marsh Creek & 55 & $(0)$ & 380 & 169 & 0 & 0 \\
\hline Sulphur Creek & 483 & (0) & 559 & 0 & 0 & 0 \\
\hline Lake Creek & 50 & $(0)$ & 91 & 23 & 0 & 12 \\
\hline \multirow[t]{2}{*}{ Totals } & 3,741 & $(431)$ & 7,736 & 1,688 & 12 & 56 \\
\hline & Sculpin & Dace & \multicolumn{2}{|c|}{ Sucker } & Whitefish & Shiner \\
\hline Bear Valley Creek & 841 & 167 & \multicolumn{2}{|c|}{357} & 18 & 0 \\
\hline Elk Creek & 573 & 4 & \multicolumn{2}{|c|}{134} & 268 & 0 \\
\hline Cape Horn Creek & 781 & 0 & \multicolumn{2}{|c|}{0} & 0 & 0 \\
\hline Valley Creek & 2,134 & 258 & \multicolumn{2}{|c|}{116} & 131 & 2 \\
\hline Camas Creek & 0 & 0 & \multicolumn{2}{|c|}{0} & 8 & 0 \\
\hline Herd Creek & 459 & 0 & \multicolumn{2}{|c|}{0} & 73 & 0 \\
\hline Big Creek (upper) & 1,459 & 0 & \multicolumn{2}{|c|}{0} & 1 & 0 \\
\hline Big Creek (lower) & 397 & 116 & \multicolumn{2}{|c|}{29} & 4 & 0 \\
\hline Loon Creek & 621 & 1 & \multicolumn{2}{|c|}{0} & 10 & 0 \\
\hline Marsh Creek & 646 & 1 & \multicolumn{2}{|c|}{0} & 2 & 0 \\
\hline Sulphur Creek & 2,965 & 4 & \multicolumn{2}{|c|}{10} & 3 & 0 \\
\hline Lake Creek & 514 & 6 & \multicolumn{2}{|c|}{0} & 1 & 0 \\
\hline Totals & 11,390 & 557 & \multicolumn{2}{|c|}{646} & 519 & 2 \\
\hline
\end{tabular}


Mortality associated with collection and tagging procedures was low (Table 3; Appendix Table 3). Overall collection mortality was 1.4\% and overall tagging and $24 \mathrm{~h}$ delayed mortality was $0.03 \%$. The overall observed mortality was $1.4 \%$. In addition, one lost tag $(0.01 \%)$ was observed during field work in 2007.

Table 3. Mortality percentages for wild Chinook salmon parr collected and PIT-tagged in Idaho in July and August 2007. There was one lost tag for the study.

\begin{tabular}{lccc}
\hline & \multicolumn{3}{c}{ Mortality (\%) } \\
\cline { 2 - 4 } & Collection & $\begin{array}{c}\text { Tagging and } \\
\text { 24-h }\end{array}$ & Overall \\
\hline Bear Valley Creek & 3.2 & 0.2 & 3.3 \\
Elk Creek & 0.4 & 0 & 0.4 \\
Cape Horn Creek & 1.3 & 0 & 1.3 \\
Valley Creek & 1.2 & 0.03 & 1.2 \\
Camas Creek & 2.1 & 0 & 2.1 \\
Herd Creek & 3.0 & 0 & 3.0 \\
Big Creek (upper) & 1.0 & 0.2 & 1.2 \\
Big Creek (lower) & 0.8 & 0 & 0.8 \\
Loon Creek & 1.0 & 0 & 1.0 \\
Marsh Creek & 0.7 & 0 & 0.7 \\
Suphur Creek & 2.5 & 0 & 2.5 \\
Lake Creek & 0.5 & 0 & 0.5 \\
Totals or averages & 1.4 & 0.03 & 1.4 \\
\hline
\end{tabular}




\section{Detections at Instream PIT-Tag Monitors}

From 1 to 4 August 2007, 2,524 wild Chinook salmon parr were collected, PIT tagged, and released in natal rearing areas from 3 to $11 \mathrm{~km}$ above the upstream PIT-tag instream monitor (VC1) in lower Valley Creek (Table 1). Between 2 August 2007 and 30 June 2008, the four instream antennas at VC1 and VC2 had 218 unique detections of these summer-tagged Chinook salmon juveniles (Figure 2). Median downstream travel time between sites for the 18 fish detected at both monitoring sites was approximately $8.2 \mathrm{~h}$ (range from $14 \mathrm{~min}$ to $5 \mathrm{~d}$ ).

Of the 218 detections, $156(71.6 \%)$ occurred at monitors in late summer/fall (August-October); 26 (11.9\%) were detected in winter (November-February); and 36 $(16.5 \%)$ were detected in spring (March-June; Figure 2). Based on detections at downstream dams, the overall efficiency of $\mathrm{VC} 1$ or $\mathrm{VC} 2$ for detecting these fish was $21.1 \%$. Based on this efficiency, an estimated $40.8 \%$ of all summer-tagged parr survived to migrate out of this stream and their survival from that point to Lower Granite Dam was $26.5 \%$.

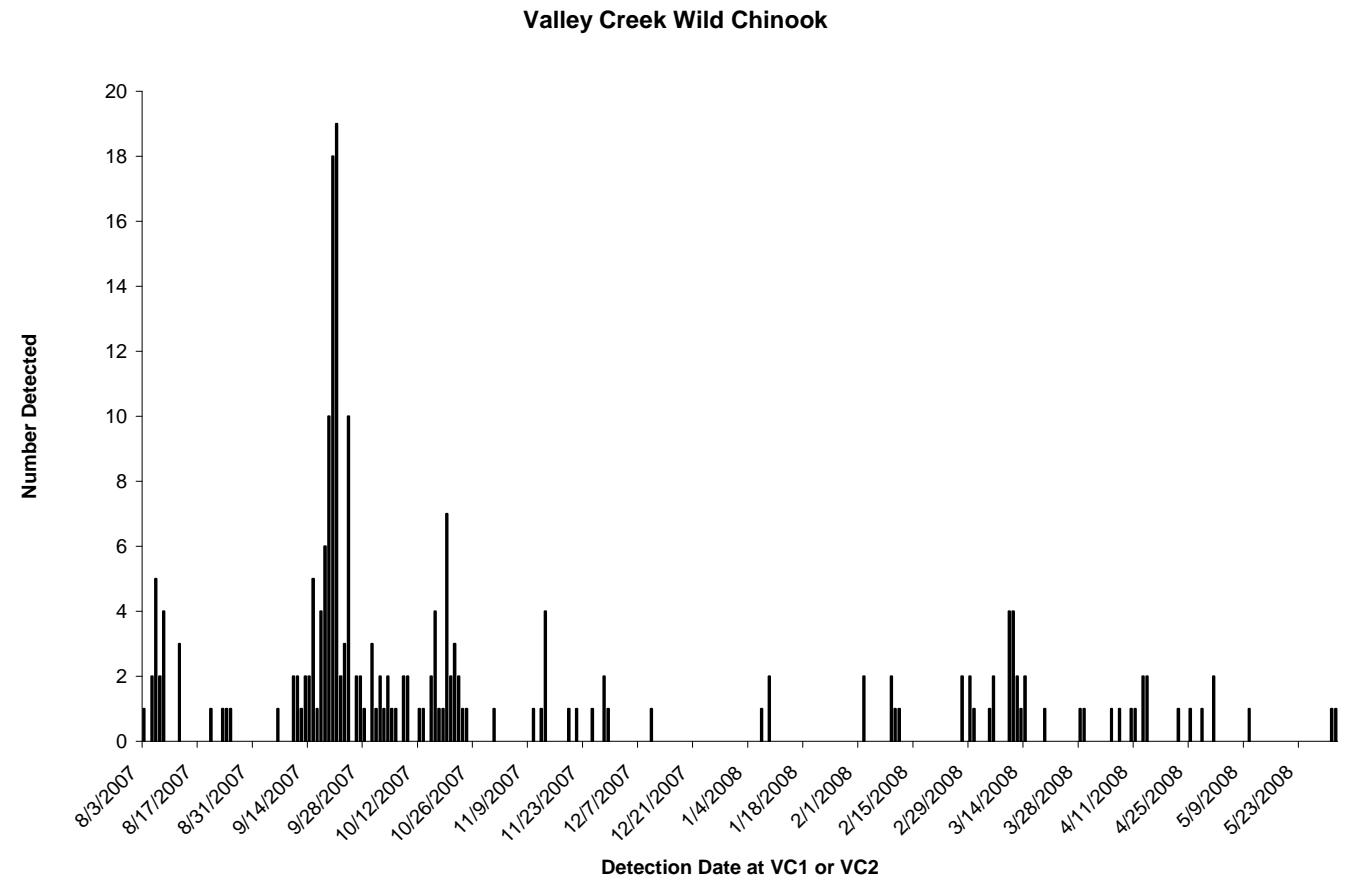

Figure 2. Detections of 218 PIT-tagged wild spring/summer Chinook salmon parr, presmolts, and smolts at the upper (VC1) and lower (VC2) instream PIT-tag monitoring antennas in lower Valley Creek from August 2007 through June 2008. A total of 2,524 Chinook salmon parr were PIT tagged and released in areas from 3 to 11 kilometers above these antennas from 1 to 4 August 2007. 
The fork lengths and median fork lengths (at tagging) of the 218 detected fish in lower Valley Creek from August 2007 to June 2008, showed no apparent timing trend throughout this period (Figure 3).

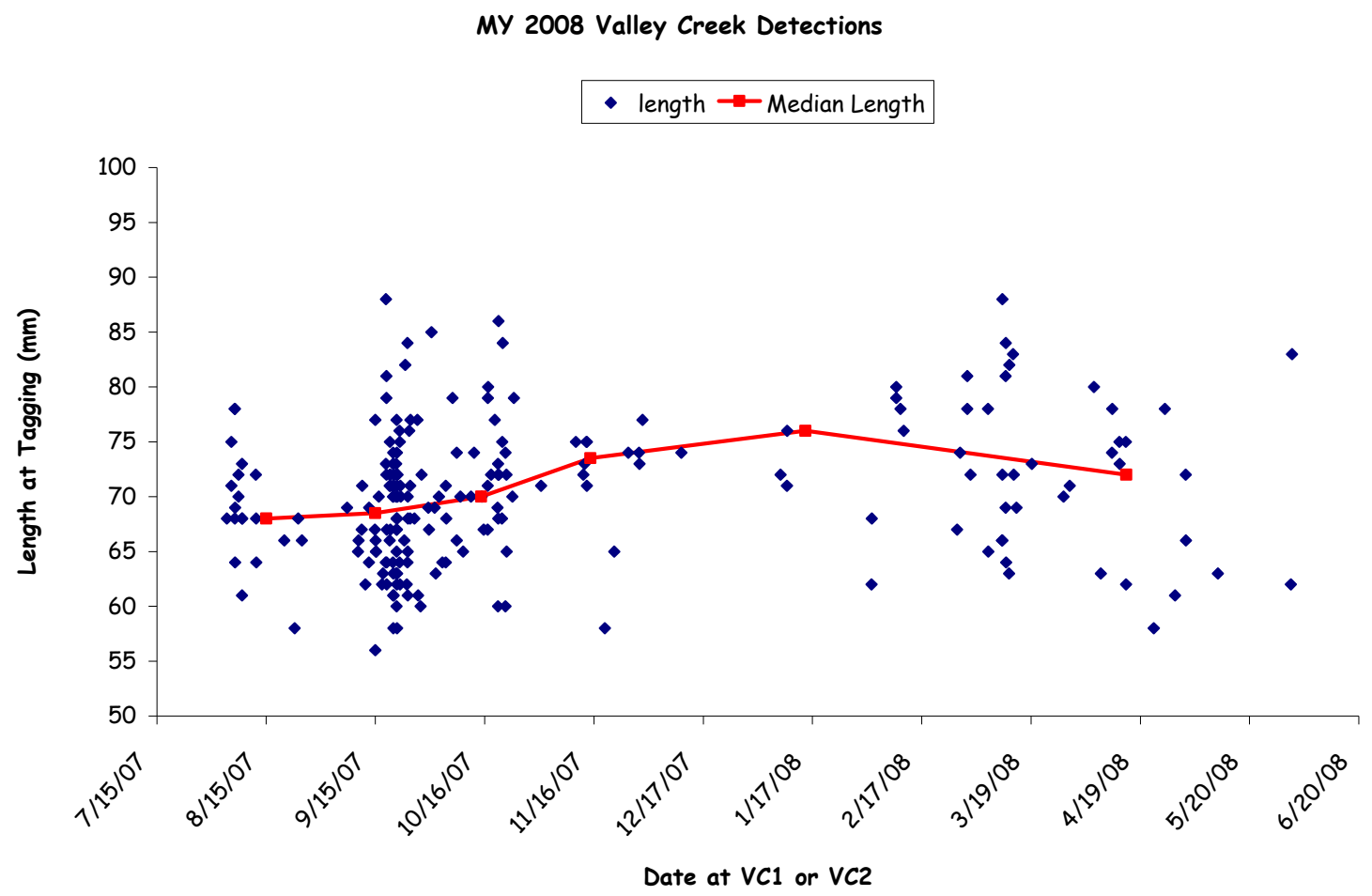

Figure 3. The fork lengths and median fork lengths of 218 summer-tagged parr that were detected at the upper and lower instream PIT-tag monitoring antennas in lower Valley Creek from August 2007 through June 2008.

\section{Recaptures at Traps and Dams}

A total of 507 wild fish PIT-tagged in summer 2007 were recaptured at traps above Lower Granite Dam from summer/fall 2007 to spring 2008, and 505 were recaptured in the separation-by-code system at the Little Goose Dam juvenile fish facility (Table 4). Depending on the time between tagging and recapture, fish had variable increases in weight and length. 
Table 4. Recapture information on PIT-tagged wild spring/summer Chinook salmon from Idaho PIT-tagged in summer 2007 (or 2006) and recaptured at Little Goose Dam in 2008. Fish were diverted by the separation-by-code system in the juvenile fish bypass system at traps and dams in summer and fall 2007 and spring 2008.

\begin{tabular}{|c|c|c|c|c|c|c|c|c|c|c|c|}
\hline & \multirow{2}{*}{$\begin{array}{l}\text { Number } \\
\text { recaptured }\end{array}$} & \multicolumn{3}{|c|}{ Length gain (mm) } & \multicolumn{3}{|c|}{ Weight gain $(\mathrm{g})$} & \multicolumn{2}{|c|}{ Condition Factor (avg) } & \multicolumn{2}{|c|}{$\begin{array}{l}\text { Recapture interval } \\
\text { (d) }\end{array}$} \\
\hline & & $\mathrm{n}$ & range & mean & $\mathrm{n}$ & range & mean & release & recapture & range & mean \\
\hline \multicolumn{12}{|c|}{ Fish recaptured at Little Goose Dam (by stream) } \\
\hline Bear Valley Creek & 41 & 41 & $32-68$ & 46.3 & 32 & $6.5-21.3$ & 12.3 & 1.23 & 1.04 & $279-323$ & 299 \\
\hline Elk Creek & 43 & 43 & $21-64$ & 42.4 & 41 & $4-20.4$ & 10.9 & 1.25 & 1.04 & $285-333$ & 296 \\
\hline Sulphur Creek & 31 & 31 & $23-55$ & 37.1 & 27 & $3.8-15.6$ & 8.9 & 1.35 & 1.08 & $278-316$ & 293 \\
\hline Marsh Creek & 28 & 28 & $17-59$ & 37.5 & 18 & $6.2-15$ & 9.7 & 1.27 & 1.08 & $281-298$ & 291 \\
\hline Cape Horn Creek & 43 & 43 & $28-64$ & 44.8 & 15 & $8.3-17.2$ & 11.8 & 1.15 & 1.10 & $276-313$ & 292 \\
\hline Valley Creek & 99 & 99 & $24-61$ & 40.0 & 55 & $4.8-15.5$ & 9.7 & 1.23 & 1.03 & $273-315$ & 289 \\
\hline Loon Creek & 30 & 30 & $26-61$ & 45.7 & 17 & $6.2-17.2$ & 12.0 & 1.22 & 1.04 & $265-300$ & 285 \\
\hline Camas Creek & 41 & 41 & $24-65$ & 46.1 & 18 & $9-19.2$ & 13.5 & 1.22 & 1.02 & $272-300$ & 284 \\
\hline Herd Creek & 35 & 35 & $22-52$ & 31.6 & 4 & $4-8.1$ & 6.8 & 1.30 & 1.07 & $277-303$ & 285 \\
\hline Big Creek (upper) & 64 & 64 & $20-59$ & 36.2 & 43 & $4.6-16.0$ & 9.1 & 1.32 & 1.08 & $253-289$ & 271 \\
\hline Big Creek (lower) & 20 & 20 & $25-59$ & 43.7 & 18 & $4.3-18.4$ & 11.9 & 1.20 & 1.00 & $267-287$ & 275 \\
\hline Secesh River & 1 & 1 & 59 & --- & 0 & --- & --- & --- & 1.02 & --- & 678 \\
\hline Lake Creek & 29 & 29 & $23-65$ & 43.3 & 2 & $9.8-20.0$ & 14.9 & 1.29 & 1.05 & $267-628$ & 290 \\
\hline Totals or averages & 505 & 505 & $17-68$ & 40.1 & 290 & $3.8-21.3$ & 10.6 & 1.25 & 1.05 & $253-678$ & 288 \\
\hline
\end{tabular}


Table 4. Continued.

\begin{tabular}{|c|c|c|c|c|c|c|c|c|c|c|c|}
\hline & \multirow{2}{*}{$\begin{array}{l}\text { Number } \\
\text { recaptured }\end{array}$} & \multicolumn{3}{|c|}{ Length gain $(\mathrm{mm})$} & \multicolumn{3}{|c|}{ Weight gain (g) } & \multicolumn{2}{|c|}{ Condition Factor (avg) } & \multicolumn{2}{|c|}{$\begin{array}{l}\text { Recapture interval } \\
\text { (d) }\end{array}$} \\
\hline & & $\mathrm{n}$ & range & mean & $\mathrm{n}$ & range & mean & release & recapture & range & mean \\
\hline \multicolumn{12}{|c|}{ Fish recaptured in traps } \\
\hline \multicolumn{12}{|c|}{ Big Creek (Taylor Ranch) } \\
\hline UBC-fall & 109 & 109 & $-2-10$ & 4.4 & 60 & $-1.4-2.1$ & $-0 . .1$ & 1.30 & 1.08 & $10-80$ & 55 \\
\hline UBC-spr. & 5 & 5 & $11-22$ & 16.8 & 5 & $0.5-4.1$ & 2.6 & 1.35 & 1.11 & $234-246$ & 239 \\
\hline LBC-fall & 8 & 8 & $-2-14$ & 3.4 & 6 & $-0.3-2$ & 0.2 & 1.22 & 1.13 & $1-76$ & 20 \\
\hline \multicolumn{12}{|l|}{ Lake Creek } \\
\hline Fall & 173 & 173 & $-4-20$ & 5.3 & 23 & $-0.6-6.0$ & 1.0 & 1.22 & 1.11 & $1-80$ & 34 \\
\hline Fall-Pre-males & 2 & 2 & $40-43$ & 41.5 & 0 & --- & --- & --- & 1.31 & $359-365$ & 362 \\
\hline Spring & 1 & 1 & 25 & --- & 0 & --- & --- & --- & 1.14 & --- & 266 \\
\hline \multicolumn{12}{|l|}{ Secesh River } \\
\hline Upper trap-fall & 65 & 65 & $-4-19$ & 6.4 & 0 & --- & --- & --- & 1.10 & $3-73$ & 44 \\
\hline Lower trap-fall & 25 & 25 & $1-20$ & 9.2 & 0 & --- & --- & --- & 1.08 & $38-68$ & 58 \\
\hline \multicolumn{12}{|l|}{ Marsh Creek } \\
\hline Fall & 97 & 97 & $-6-19$ & 5.1 & 0 & --- & --- & 1.20 & --- & $1-89$ & 42 \\
\hline Salmon R. (spr only) & 15 & 12 & $21-48$ & 28.7 & 0 & --- & --- & 1.23 & --- & $237-275$ & 256 \\
\hline Snake R. (spr only) & 7 & 7 & $36-58$ & 43.6 & 0 & --- & --- & 1.14 & --- & $249-293$ & 281 \\
\hline Totals & 507 & 504 & --- & --- & 94 & --- & --- & --- & --- & --- & --- \\
\hline \multicolumn{12}{|c|}{ Fish recaptured at other collector dams } \\
\hline Lower Granite Dam & 5 & 0 & --- & --- & 0 & --- & --- & --- & --- & 274-285 & 279 \\
\hline Totals & 5 & 0 & --- & --- & 0 & --- & --- & --- & --- & --- & --- \\
\hline
\end{tabular}




\section{Detections at Dams}

Based on expanded detections (1,552 fish) ${ }^{\mathbf{1}}$ at Lower Granite Dam from 21 April to 16 June 2008, estimated parr-to-smolt survival for Idaho fish averaged $21.0 \%$ (SE 1.0\%; SE range 1.0-7.0\%; Table 5; Appendix Tables 5-17). An additional 596 first-time detections (unadjusted) were recorded at Little Goose, Lower Monumental, Ice Harbor, McNary, John Day, and Bonneville Dams, and the PIT-tag trawl near the mouth of the Columbia River (Appendix Tables 18-23). By comparing all first-time detections at interrogation dams/sites $(1,175)$ to the expanded number of detections at Lower Granite Dam $(1,552)$, we estimated that $24.3 \%$ of the wild fish from Idaho passed through the dams undetected.

Table 5. Summary of observed and expanded detections of PIT-tagged wild spring/summer Chinook salmon smolts from Idaho at Lower Granite Dam in 2008. Table includes expanded numbers used for parr-to-smolt survival estimates and also includes standard error percentages (SE\%). See Table 1 for numbers released.

\begin{tabular}{|c|c|c|c|c|}
\hline \multirow[b]{3}{*}{ Stream } & \multicolumn{4}{|c|}{ Lower Granite Dam Detections } \\
\hline & \multicolumn{2}{|c|}{ Observed } & \multicolumn{2}{|c|}{ Expanded } \\
\hline & $\mathrm{N}$ & $\%$ & $\mathrm{~N}$ & $\%(\mathrm{SE} \%)$ \\
\hline Bear Valley Creek & 34 & 6.6 & 91 & $17.7(3)$ \\
\hline Elk Creek & 51 & 10.2 & 125 & $25.0(4)$ \\
\hline Marsh Creek & 40 & 8.0 & 96 & $19.2(3)$ \\
\hline Cape Horn Creek & 46 & 9.2 & 134 & $26.9(4)$ \\
\hline Sulphur Creek & 34 & 9.1 & 87 & $23.1(4)$ \\
\hline Valley Creek & 118 & 4.7 & 305 & $12.1(1)$ \\
\hline Loon Creek & 36 & 13.0 & 106 & $38.4(7)$ \\
\hline Camas Creek & 46 & 9.1 & 124 & $24.5(4)$ \\
\hline Herd Creek & 44 & 13.7 & 107 & $33.4(5)$ \\
\hline Big Creek (upper) & 62 & 9.9 & 203 & $32.3(5)$ \\
\hline Big Creek (lower) & 25 & 10.1 & 64 & $25.9(5)$ \\
\hline Lake Creek & 43 & 8.6 & 110 & $21.9(4)$ \\
\hline Totals or averages & 579 & 7.8 & 1,552 & $21.0(1)$ \\
\hline
\end{tabular}

${ }^{1}$ Due to rounding, expanded detection numbers at Lower Granite Dam in Table 5 may vary slightly from numbers in Appendix Tables 5-17. 
For parr tagged in Idaho, average fork length at release was $69.8 \mathrm{~mm}$ (Table 1; Appendix Table 1). However, among fish from this group that were detected the following spring at dams, average fork length at release was significantly longer, although marginally so $(70.7 \mathrm{~mm} ; P<0.01)$. Also, fish that were larger at release tended to pass Lower Granite Dam earlier than those that were smaller $(P<0.01$; Figure 4$)$. The release-length distribution of detected fish at the dams/trawl was also significantly different from that of released fish in all length categories, except $\leq 59 \mathrm{~mm}, 65-69 \mathrm{~mm}$, 75-79 $\mathrm{mm}$, and 85-89 $\mathrm{mm}(P<0.05$; Figure 5).

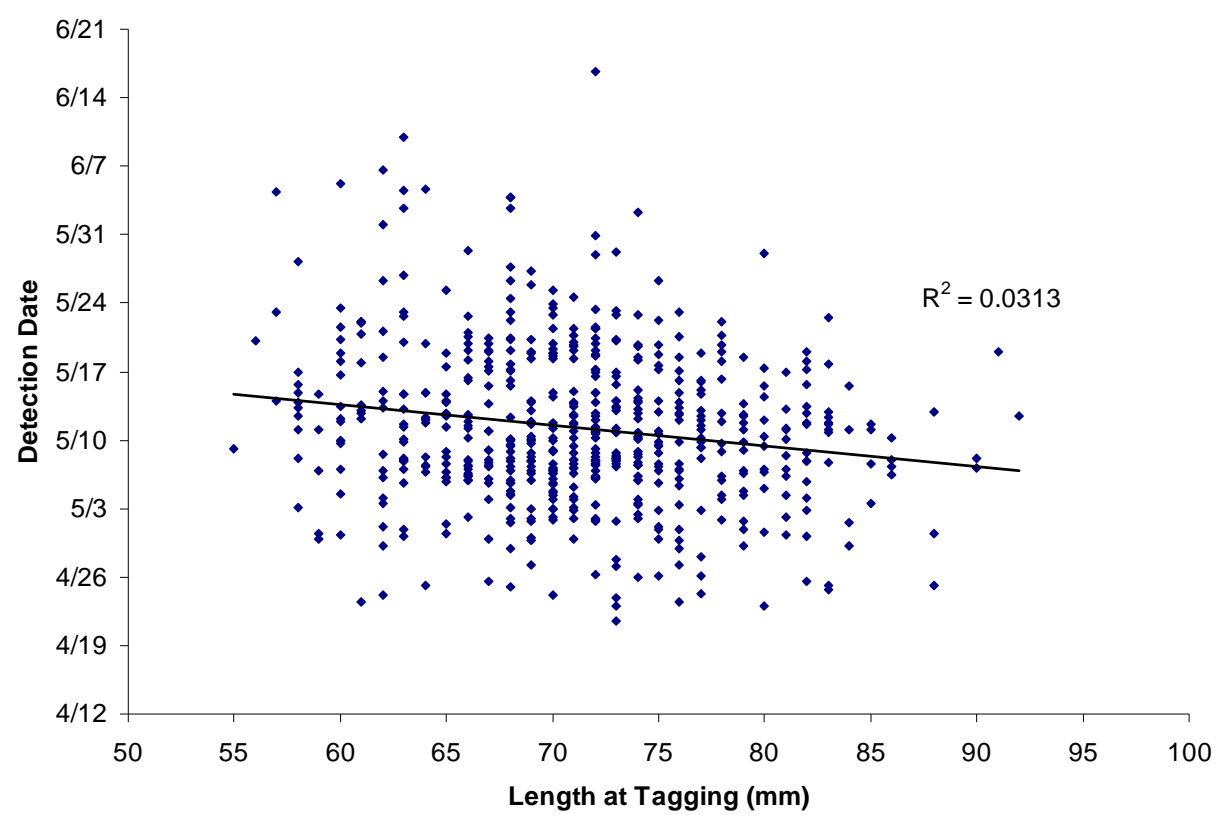

Figure 4. Relationship between fork length of parr at tagging (in 2007) and detection date at Lower Granite Dam in 2008.

In 2008, we found a significant difference in fork lengths at time of release for fish that passed Lower Granite Dam in April and May compared to those that passed after May $(P<0.0001)$. Fish migrating through the dam in April and May were on average $6.1 \mathrm{~mm}$ larger when released than fish migrating after May. However, only 12 fish migrated through the dam after May. These data suggest that fish size influences migration timing or overwintering location. 


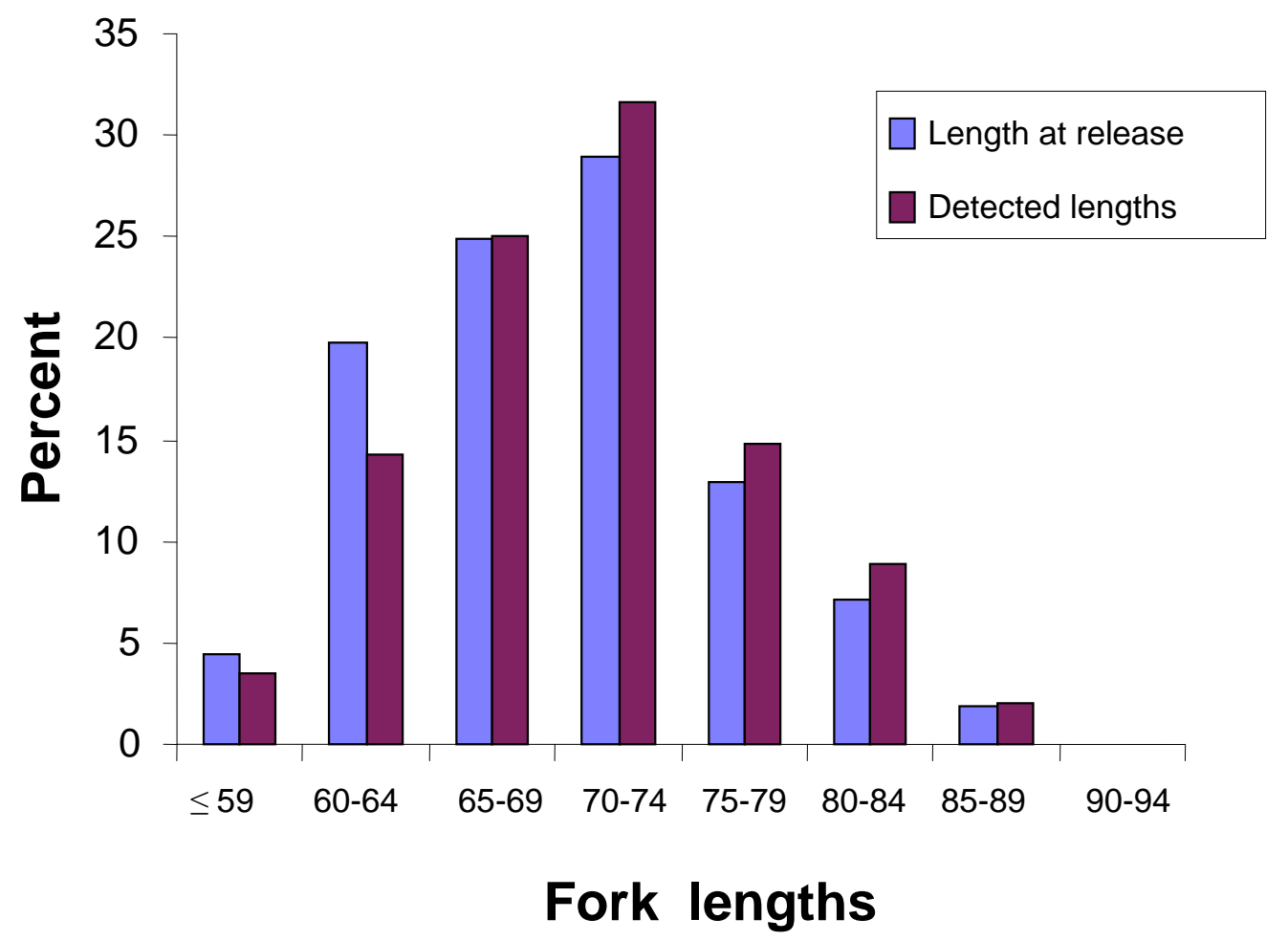

Figure 5. Percent by fork length increments (mm), of PIT-tagged wild spring/summer Chinook salmon parr released in Idaho streams in $2007(\mathrm{n}=7,385)$ and percent of fish detected for these length increments at dams/trawl in spring and summer $2008(n=1,175)$.

In 2008, we estimated a $26.5 \%$ overall survival rate to Lower Granite Dam for Chinook salmon juveniles previously detected at the Valley Creek instream PIT-tag monitors. Overall estimated parr-to-smolt survival for fish from this stream was $12.1 \%$ (Table 5). Estimated survival rates for the various groups of fish leaving this stream in 2007-2008 were $15.5 \%$ for fish leaving the stream in late summer/fall, $48.0 \%$ for fish leaving the stream in winter, and $58.5 \%$ for fish leaving the stream in spring. 


\section{Migration Timing}

\section{Lower Granite Dam}

Passage timing at Lower Granite Dam varied for fish from 16 Idaho and Oregon stream populations (Figure 6). In comparisons among 16 Idaho and Oregon stream populations (Appendix Table 4a-4b, Figure 6), fish from the upper Imnaha River had a significantly earlier timing for 10th percentile passage than fish from all the other streams $(P<0.05)$. The 10th percentile passage date of fish from Loon Creek was significantly later than that of fish from all other streams except Bear Valley, Lake, Elk, Cape Horn, Sulphur, upper Big, and Catherine Creeks $(P<0.05)$. Standard errors on these passage estimates ranged from 0.9 to $3.0 \mathrm{~d}$ (median $1.6 \mathrm{~d}$ ). Overall, the 10 th percentile passage dates for fish from 16 stream populations ranged from 17 April to 7 May (Appendix Tables 4a-4b).

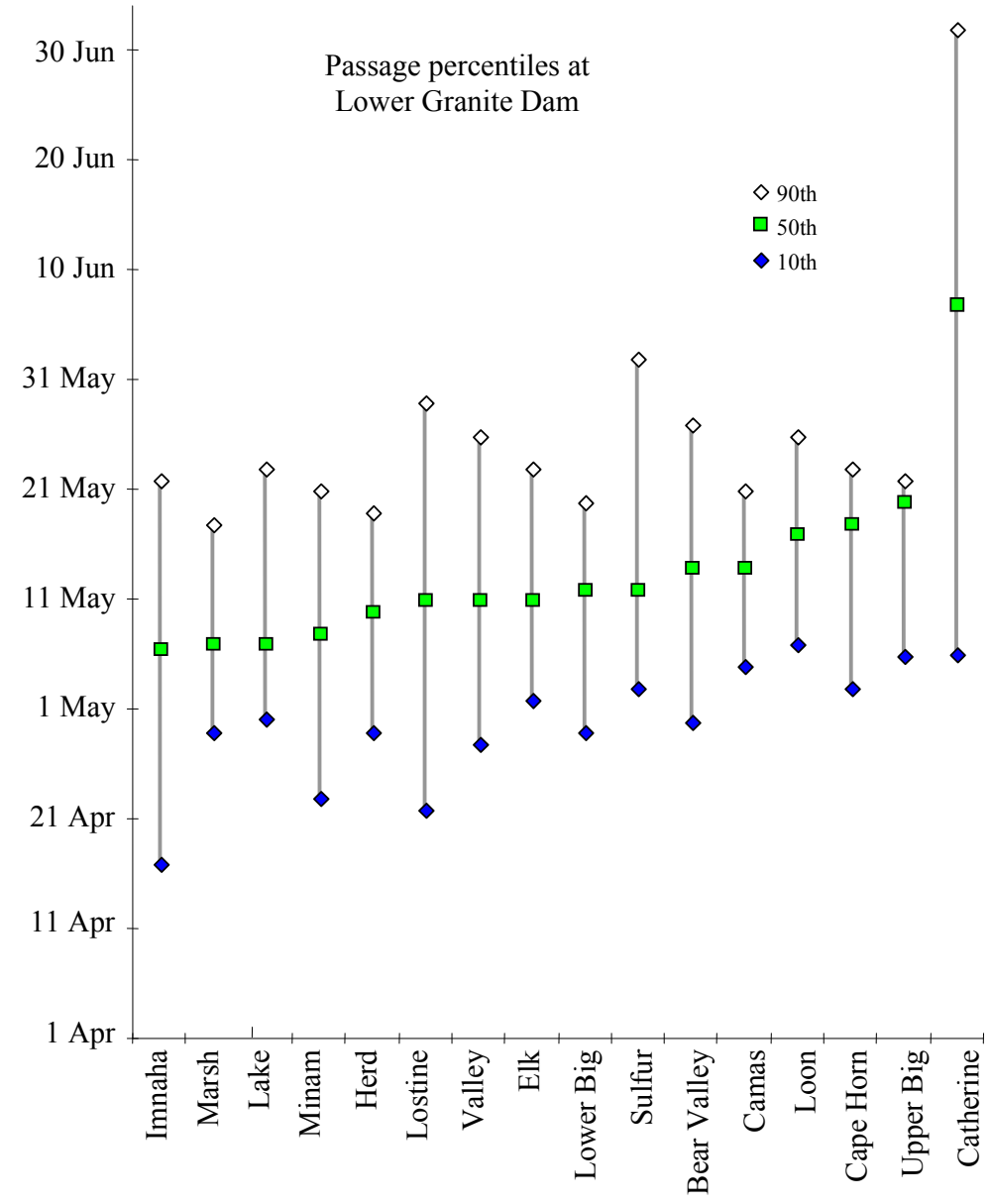

Figure 6. Estimated passage distributions at Lower Granite Dam in 2008 for wild spring/summer Chinook salmon smolts from streams of Idaho and Oregon. Big Creek is divided into lower and upper portions for these analyses. Daily estimated passage numbers for Idaho streams shown in Appendix Tables 5-17. 
In comparisons of the 50th percentile passage date at the dam, fish from the upper Imnaha River were significantly earlier than fish from all other streams except Lake, Marsh, and Herd Creeks and the Minam River $(P<0.05)$. Fish from Catherine Creek arrived significantly later at the dam than fish from all other streams $(P<0.05)$. Standard errors on these passage estimates ranged from 0.5 to $3.8 \mathrm{~d}$ (median $0.9 \mathrm{~d}$ ). The overall 50th percentile passage dates for fish from 16 stream populations ranged from 6 May to 7 June (Appendix Tables 4a-4b).

In terms of the 90th percentile passage date at the dam, fish from Marsh, Herd, lower Big, and Camas Creeks and the Minam River were significantly earlier than fish from all other streams except upper Big, Cape Horn, Elk, and Lake Creeks and the upper Imnaha River $(P<0.05)$. Fish from Catherine Creek were significantly later at the dam than fish from all other stream populations $(P<0.05)$. The standard errors on these passage estimates ranged from 0.5 to $4.4 \mathrm{~d}$ (median $1.2 \mathrm{~d}$ ). The overall 90th percentile passage dates for fish from all streams ranged from 18 May to 2 July (Appendix Tables $4 a-4 b)$.

For the number of days encompassing the middle 80th percentile passage (10th to 90th percentile), Camas and upper Big Creek fish had a significantly more condensed distribution (16 d) than fish from all other streams except Loon, Marsh, Cape Horn, Herd, Elk, lower Big, and Lake Creeks (19-23 d; $P<0.05$; Appendix Tables 4a-4b). Fish from Catherine Creek displayed significantly more protracted timing behavior than fish from all other stream populations at the dam ( $57 \mathrm{~d}$ vs. $16-37 \mathrm{~d} ; P<0.05)$. The standard errors for these passage estimates range from 1.0 to $4.6 \mathrm{~d}$ (median $2.0 \mathrm{~d}$ ).

Migration timing at Lower Granite Dam based on streams with 8 or more years of data indicated that 10th, 50th, and 90th percentage of passage timing of fish varied between streams (Table 6). Secesh River fish had a significantly earlier timing at Lower Granite Dam for the 10th percentile passage than fish from all other streams except Lake Creek, and Lostine and upper Imnaha Rivers $(P<0.05)$. Also, upper Big Creek fish had significantly later migration timing at the dam than all the other streams except Camas, Catherine, and Loon Creeks $(P<0.05)$. 
Table 6. The 95\% confidence interval (CI) and mean passage dates (10th, 50th, and 90th percentiles), with standard errors (SE) in days, at Lower Granite Dam for wild spring/summer Chinook salmon smolts from streams in Idaho and Oregon over all data years.

\begin{tabular}{|c|c|c|c|c|}
\hline \multirow[b]{2}{*}{ Stream } & \multicolumn{3}{|c|}{ Percentile passage dates at Lower Granite Dam (95\% CI, mean, SE) } & \multirow[b]{2}{*}{ Data years } \\
\hline & 10th (SE) & 50th $(\mathrm{SE})$ & 90th (SE) & \\
\hline Secesh River & 11-17 April, 14 April (1) & 23-29 April, 26 April (1) & 23 May-6 June, 30 May (3) & 19 \\
\hline South Fork Salmon River & 16-24 April, 20 April (2) & 7-13 May, 10 May (1) & 2 June-11 June, 6 June (2) & 17 \\
\hline Catherine Creek & 23-30 April, 26 April (2) & 10-19 May, 14 May (2) & 28 May-9 June, 3 June (3) & 18 \\
\hline Imnaha River (upper) & 14-19 April, 17 April (1) & 28 April-5 May, 2 May (2) & 17-26 May, 21 May (2) & 16 \\
\hline Bear Valley Creek & 18-25 April, 22 April (2) & 4-11 May, 8 May (2) & 25 May-4 June, 30 May (2) & 17 \\
\hline Big Creek (upper) & 25 April-4 May, 30 April (2) & 12-24 May, 18 May (3) & 27 May-16 June, 6 June (4) & 14 \\
\hline Elk Creek & 16-25 April, 20 April (2) & 2-9 May, 6 May (2) & 23 May-2 June, 28 May (2) & 16 \\
\hline Valley Creek & 21-29 April, 25 April (2) & 9-18 May, 13 May (2) & 30 May-11 June, 5 June (3) & 17 \\
\hline Marsh Creek & 17-23 April, 20 April (1) & 1-8 May, 5 May (2) & 19-28 May, 24 May (2) & 14 \\
\hline Lake Creek & 12-19 April, 16 April (2) & 26 April-4 May, 30 April (2) & 23 May-08 June, 31 May (4) & 16 \\
\hline Lostine River & 13-20 April, 17 April (2) & 1-07 May, 4 May (2) & 18-26 May, 22 May (2) & 17 \\
\hline Sulphur Creek & 15-28 April, 21 April (3) & 1-17 May, 9 May (3) & 21 May-5 June, 28 May (3) & 10 \\
\hline Cape Horn Creek & 19-30 April, 24 April (2) & 6-17 May, 12 May (3) & 23 May-7 June, 30 May (3) & 12 \\
\hline Big (lower)/Rush Creeks & 16-22 April, 19 April (1) & 26 April-2 May, 29 April (1) & 9-16 May, 12 May (2) & 12 \\
\hline E. Fork Salmon River & 15-24 April, 19 April (2) & 25 April-7 May, 1 May (2) & 13-23 May, 18 May (2) & 7 \\
\hline Loon Creek & 21 April-02 May, 27 April (2) & 4-15 May, 9 May (2) & 15-27 May , 21 May (2) & 10 \\
\hline Herd Creek & 17-24 April, 21 April (2) & 26 April-4 May, 30 April (2) & 11-18 May, 14 May (2) & 11 \\
\hline Grand Ronde River (upper) & 23 April-10 May, 1 May (3) & 13 May-4 June, 24 May (4) & 21 May-3 July, 12 June (8) & 5 \\
\hline Imnaha River (lower) & 5-20 April, 12 April (2) & 14 April-5 May, 25 April (3) & 2-15 May, 9 May (2) & 4 \\
\hline Chamb/WF Chamberlain Cr & 15-24 April, 20 April (2) & 28 April-9 May, 4 May (2) & 14 May-13 June, 29 May (7) & 10 \\
\hline Camas Creek & 23 April-1 May, 27 April (2) & 6-17 May, 12 May (2) & 21-30 May, 25 May (2) & 10 \\
\hline Minam River & 13-22 April, 17 April (2) & 29 April-10 May, 5 May (2) & 16-27 May, 21 May (2) & 7 \\
\hline
\end{tabular}


For the 50th percentile passage at the dam, Secesh River fish had significantly earlier arrival timing than fish from all the other streams except lower Big, Lake, and Herd Creeks $(P<0.05)$. Fish from upper Big Creek had significantly later timing at the dam than fish from all other streams except Catherine Creek $(P<0.05)$. For the 90th percentile passage at the dam, lower Big Creek fish had significantly earlier timing than fish from all other streams except Herd and Loon Creeks $(P<0.05)$. Fish from upper Big Creek had significantly later timing at the dam than fish from all other streams except Elk, Bear Valley, W. F. Chamberlain, Cape Horn, Lake, Catherine, and Valley Creeks, and the Secesh and South Fork Salmon Rivers $(P<0.05)$.

\section{Comparison with Flows}

We grouped first-time detections (expanded) at Lower Granite Dam of all Idaho and Oregon streams combined and compared their collective timing with river flows during the same periods (Figure 7 and Appendix Table 17). Overall, passage at the dam during 2008 occurred between mid-April and early July, with the middle 80th percentile passage occurring from 30 April to 23 May (Table 7). Peak passage dates occurred during moderate flows of $87.5 \mathrm{kcfs}$ on 7 May and high flows of $197.3 \mathrm{kcfs}$ on 20 May (Appendix Table 17).

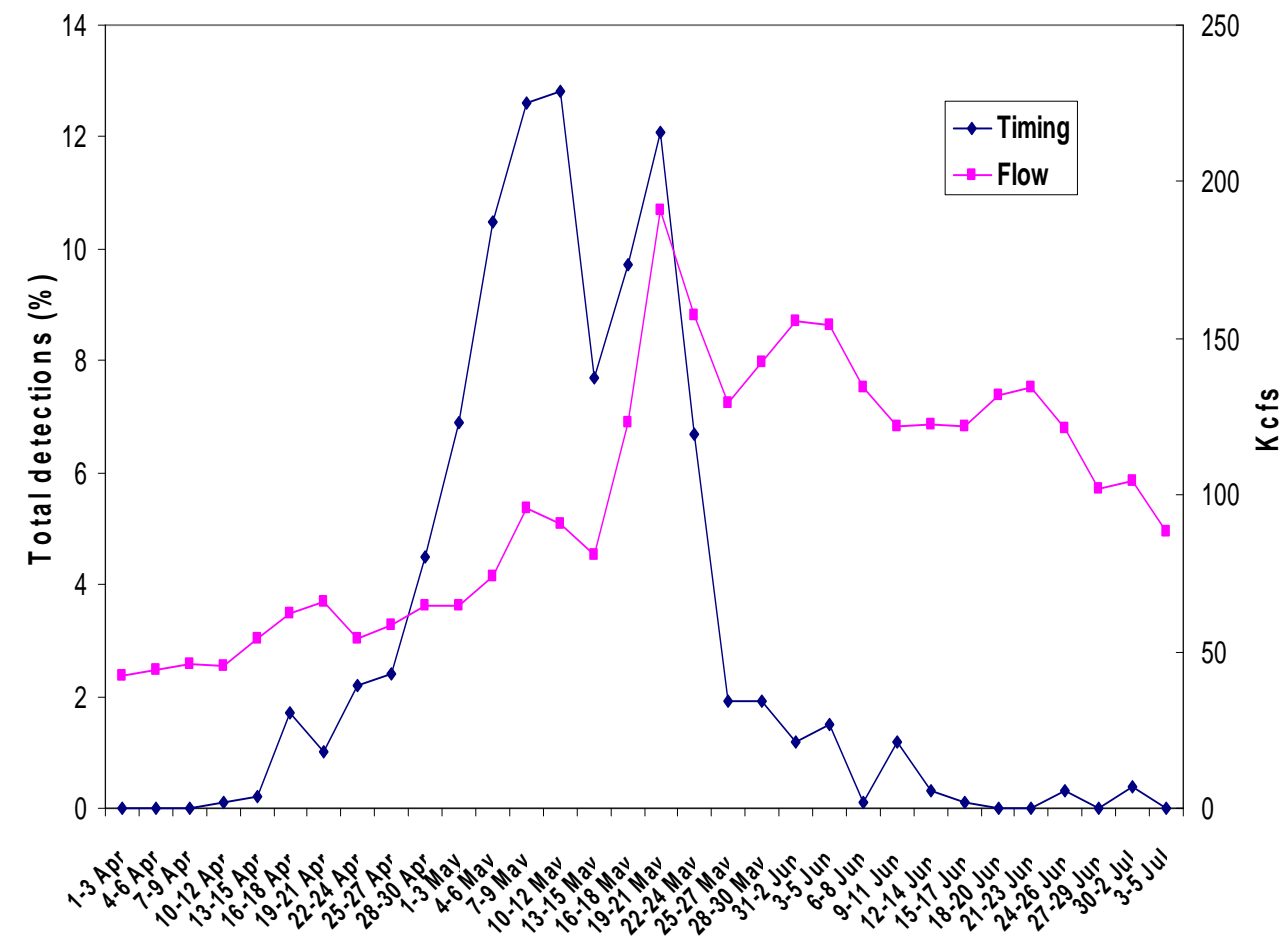

Figure 7. Overall migration timing of PIT-tagged wild spring/summer Chinook salmon smolts with associated river flows at Lower Granite Dam, 2008. Daily detections from Idaho and Oregon streams were pooled in 3-day intervals and expanded based on daily detection probability. River flows at the dam were averaged daily over the same periods. 
Table 7. Accumulated and 2008 passage dates at Lower Granite Dam for combined populations of wild spring/summer Chinook salmon smolts PIT tagged the previous summers as parr in Idaho and Oregon streams.

\begin{tabular}{|c|c|c|c|c|}
\hline \multirow[b]{2}{*}{ Year } & \multicolumn{4}{|c|}{ Dates of passage percentiles at Lower Granite Dam } \\
\hline & 10th & 50th & 90th & Range \\
\hline $1989^{a}$ & 23 April & 14 May & 13 June & 4 April-22 July \\
\hline 1990 & 19 April & 7 May & 7 June & 5 April-18 July \\
\hline 1991 & 1 May & 18 May & 12 June & 13 April-20 July \\
\hline 1992 & 15 April & 2 May & 27 May & 5 April-27 July \\
\hline 1993 & 26 April & 14 May & 31 May & 14 April-10 August \\
\hline 1994 & 22 April & 8 May & 1 June & 13 April-4 Sept. \\
\hline 1995 & 17 April & 9 May & 4 June & 8 April-22 Sept. \\
\hline $1996^{\mathrm{a}, \mathrm{b}}$ & 15 April & 27 April & 19 May & 9 April-15 July \\
\hline $1997^{\mathrm{a}, \mathrm{b}}$ & 12 April & 24 April & 18 May & 31 March-22 Sept. \\
\hline $1998^{b}$ & 11 April & 2 May & 23 May & 31 March-7 Aug. \\
\hline 1999 & 20 April & 3 May & 28 May & 27 March-8 July \\
\hline 2000 & 17 April & 7 May & 30 May & 10 April-20 July \\
\hline 2001 & 26 April & 9 May & 27 May & 6 April-7 July \\
\hline 2002 & 16 April & 3 May & 30 May & 28 March-5 July \\
\hline 2003 & 18 April & 11 May & 29 May & 31 March-4 July \\
\hline 2004 & 16 April & 3 May & 26 May & 1 April-16 July \\
\hline 2005 & 25 April & 7 May & 24 May & 4 April-20 June \\
\hline 2006 & 18 April & 2 May & 22 May & 3 April-18 June \\
\hline 2007 & 15 April & 30 April & 14 May & 5 April-18 June \\
\hline 2008 & 30 April & 11 May & 23 May & 10 April-02 July \\
\hline
\end{tabular}

${ }^{\text {a }}$ No fish were tagged from the Middle Fork of the Salmon River drainage for this migration year.

${ }^{b}$ This migration year represented by a much higher proportion of fish from Oregon streams than other years. 


\section{Environmental Information}

Environmental water quality factors varied by month and between locations (Appendix Tables 24-29), as did the percentage of fish collected and/or detected at adjacent traps or instream PIT-tag monitors (Appendix Figures 1-6). In 2007, Northwest Fisheries Science Center personnel completed the Water Quality Baseline Environmental Monitoring website for storage and dissemination of water quality data collected during this study since 1993 (NWFSC 2007). This website also has links to weather, climate, and stream flow data in the Salmon River basin. 


\section{DISCUSSION}

Mortality rates associated with collection and tagging in 2008 were comparable to those in earlier years (Achord et al. 1992; 1994-1998; 2000-2008).

The instream PIT-tag monitoring systems used in Valley Creek enabled us to calculate survival estimates and migration timing for wild Chinook salmon juveniles leaving this stream from late summer to the following spring in 2003-2004, 2004-2005, 2005-2006, 2006-2007, and 2007-2008. However, during these five periods, only 8-14\% of the tagged juvenile Chinook salmon were detected at the monitors. The addition of an MUX-transceiver and an additional antenna at each site in 2007 did not improve the precision of these survival estimates. However, due to unforeseen problems related to monitoring systems for the new SST tag, actual operation of the sites during 2007-2008 was intermittent. The improved monitoring systems in 2008 should provide better survival estimates in 2008-2009.

Antennas for the instream monitors installed at Big Creek during 2006 proved to be inappropriate for this location. These "hybrid," or hinged rectangular antennas encased in PVC pipe, had been used successfully in Valley Creek. However, in Big Creek, the hybrid antennas were largely destroyed by winter ice and floods. Therefore, in 2007, NMFS personnel began developing a new type of antenna. The new "pass-by" antenna, with a design resembling a speed-bump, was evaluated in lower Big Creek in the winter and spring of 2007-2008. These antennas survived the winter, but did not survive the very high flows in spring 2008. We concluded that almost any type of antenna installed in Big Creek must be removed before high spring flows.

Overall mean growth from the parr-to-smolt stage as measured at Little Goose Dam in $2008(0.14 \mathrm{~mm} / \mathrm{d})$ was comparable to that measured in all previous years (2001-2007; 0.13-0.16 mm/d; Achord et al. 2002-2008). Overall mean weight gain in $2008(0.037 \mathrm{~g} / \mathrm{d})$ was also comparable to that in previous years.

The annual, combined (Idaho and Oregon steams) parr-to-smolt survival estimates over the last 16 years have ranged from 8.2 to $24.4 \%$, with an average annual survival rate of $16.3 \%$ (Figure 8 ). We measured the lowest parr-to-smolt survival estimates in 2004 and 2005 at 8.2 and $8.4 \%$, respectively. These low estimates may have resulted from conditions with much higher parr density (see Figure 9 for Idaho streams). Adult returns of wild fish to the Snake River basin from 2001 to 2003 were more than a magnitude greater than returns from 1994 to 1996, when we measured the highest subsequent parr-to-smolt survival (20.6 to $24.4 \%$ ). 


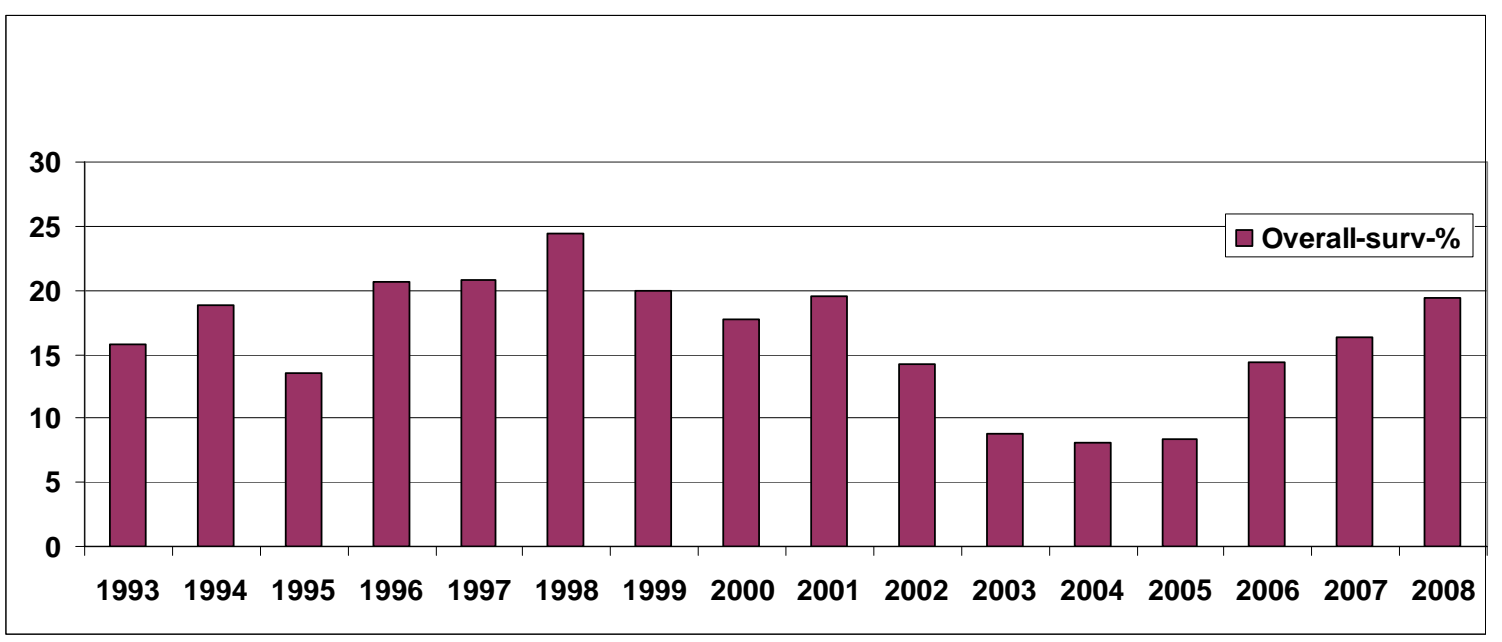

Figure 8. The overall estimated parr-to-smolt survival rates for wild spring/summer Chinook salmon from Idaho and Oregon streams to Lower Granite Dam from 1993 to 2008.

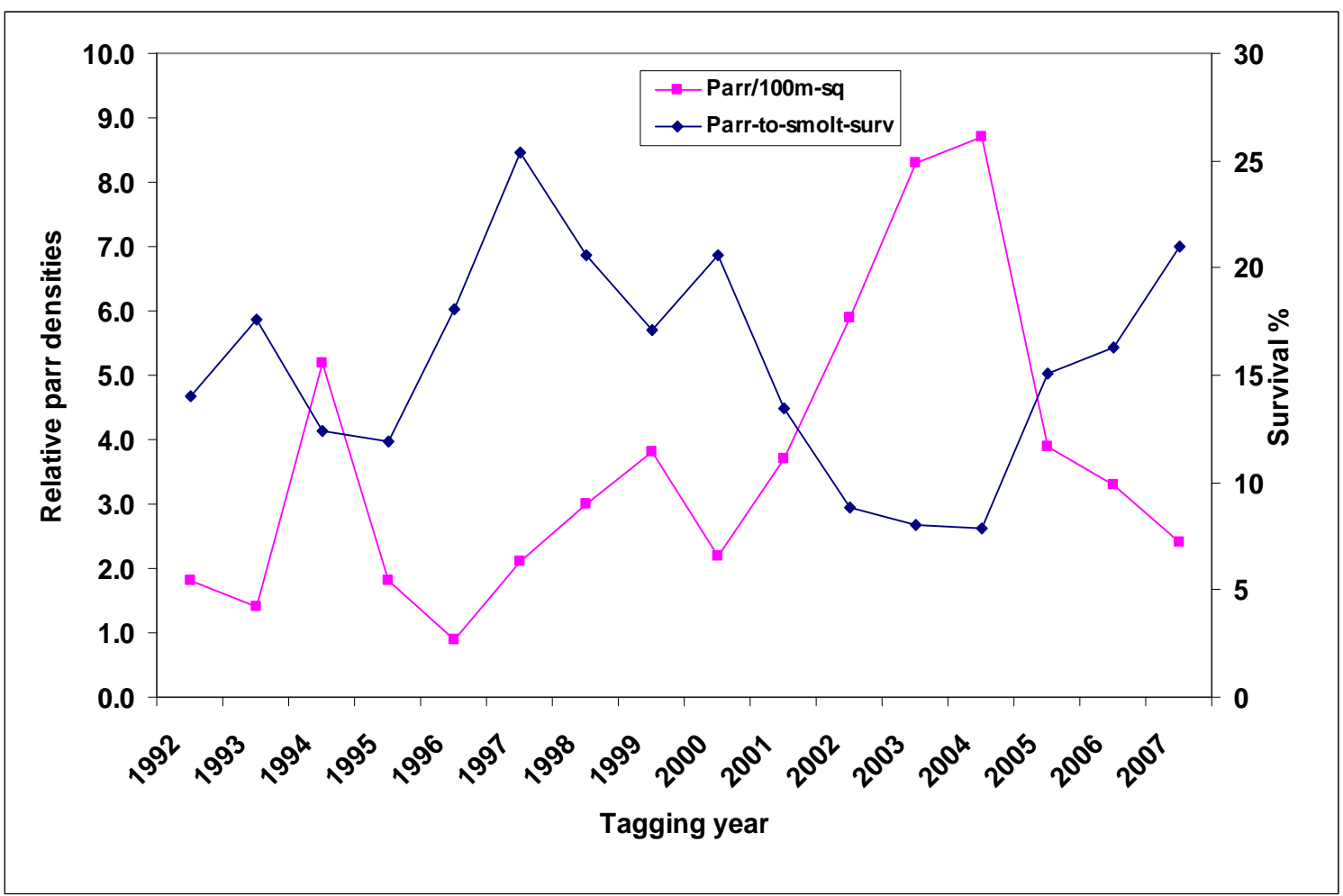

Figure 9. Annual Chinook salmon parr densities (per $100 \mathrm{~m}^{2}$ ) in areas sampled in all Idaho streams from 1992 to 2007 plotted against subsequent annual smolt survival estimate to Lower Granite Dam the following year. 
In 2008, as observed in previous years, larger fish (at tagging) tended to migrate earlier than smaller fish at Lower Granite Dam. In addition, we observed that wild fish detected at the dam early in the migration (April and May) had been significantly larger at release than fish migrating after May. This suggests that size is an important factor related to either the initiation of smoltification or to other life-history dynamics that affect the migration timing of wild fish.

In spring 2008, we observed that the overall 50th and 90th passage percentile dates for the combined stream populations occurred in mid- and late May, respectively.

Low-to-moderate flows occurred prior to mid-May and high flows thereafter, with colder-than-normal weather conditions throughout spring 2008. As we have reported previously, Chinook salmon smolt passage timing at Lower Granite Dam for individual wild populations has been highly variable and usually protracted, with timing patterns for some populations ranging from early to late spring. Complex yearly interrelationships between flow and annual climatic conditions are primary factors contributing to passage timing. However, water temperatures in streams above the dam, turbidity, physiological development, variability in stock behavior, fish size, and other yet unknown factors may all contribute substantially to wild smolt passage timing.

As additional environmental monitors, instream PIT-tag monitors, and traps are installed in study streams, we can more accurately monitor the movements of fry, parr, and smolts from rearing areas and examine relationships between these movements and environmental conditions within the streams. Mapped over time, this information, along with weather and climate data, may provide tools for the prediction of movement in different wild fish stocks. Such tools are vital to recovery planning for threatened or (ESA) endangered species of Pacific salmon. 


\section{ACKNOWLEDGMENTS}

We thank Bonneville Power Administration for funding this project and Richard Nelson, Bill Muir, Darren Ogden, Joe Lemoine, Sam Rushing, Daniel Charboneau, Jason Everett, Eva Enders, Mike Gessel, Sean Newsome, Steven Loiacono, and Richard Ledgerwood for their excellent assistance in collecting and PIT tagging fish for this study. Also, thanks to personnel from the Idaho Department of Fish and Game and the Nez Perce Tribe for providing data from trapping operations in natal rearing areas. We thank William R. Wassard, Gabriel Brooks, and Scott Davidson for maintenance of the instream PIT-tag monitoring systems in lower Valley Creek and developing the monitoring systems for lower Big Creek. 


\section{REFERENCES}

Achord, S., G. A. Axel, E. E. Hockersmith, B. P. Sandford, M. B. Eppard, and G. M. Matthews. 2001a. Monitoring the migrations of wild Snake River spring/summer Chinook salmon smolts, 1999. Report of the National Marine Fisheries Service to the Bonneville Power Administration. Document D19164-2 available at www.efw.bpa.gov/searchpublications (February 2009).

Achord, S., G. A. Axel, E. E. Hockersmith, B. P. Sandford, M. B. Eppard, and G. M. Matthews. 2001b. Monitoring the migrations of wild Snake River spring/summer Chinook salmon smolts, 2000. Report of the National Marine Fisheries Service to the Bonneville Power Administration. Document D19164-1 available at www.efw.bpa.gov/searchpublications (February 2009).

Achord, S., G. A. Axel, E. E. Hockersmith, B. P. Sandford, M. B. Eppard, and G. M. Matthews. 2002. Monitoring the migrations of wild Snake River spring/summer Chinook salmon smolts, 2001. Report of the National Marine Fisheries Service to the Bonneville Power Administration. Document 00005619-1 available at www.efw.bpa.gov/searchpublications (February 2009).

Achord, S., M. B. Eppard, E. E. Hockersmith, B. P. Sandford, G. A. Axel, and G. M. Matthews. 2000. Monitoring the migrations of wild Snake River spring/summer Chinook salmon smolts, 1998. Report of the National Marine Fisheries Service to the Bonneville Power Administration. Document 18800-7 available at www.efw.bpa.gov/searchpublications (February 2009).

Achord, S., M. B. Eppard, E. E. Hockersmith, B. P. Sandford, and G. M. Matthews. 1997. Monitoring the migrations of wild Snake River spring/summer Chinook salmon smolts, 1996. Report of the National Marine Fisheries Service to the Bonneville Power Administration. Document 18800-5 available at www.efw.bpa.gov/searchpublications (February 2009).

Achord, S., M. B. Eppard, E. E. Hockersmith, B. P. Sandford, and G. M. Matthews. 1998. Monitoring the migrations of wild Snake River spring/summer Chinook salmon smolts, 1997. Report of the National Marine Fisheries Service to the Bonneville Power Administration. Document 18800-6 available at www.efw.bpa.gov/searchpublications (February 2009).

Achord, S., M. B. Eppard, B. P. Sandford, and G. M. Matthews. 1996a. Monitoring the migrations of wild Snake River spring/summer Chinook salmon smolts, 1995. Report of the National Marine Fisheries Service to the Bonneville Power Administration. Document 18800-4 available at www.efw.bpa.gov/searchpublications (February 2009). 
Achord, S., J. R. Harmon, D. M. Marsh, B. P. Sandford, K. W. McIntyre, K. L. Thomas, N. N. Paasch, and G. M. Matthews. 1992. Research related to transportation of juvenile salmonids on the Columbia and Snake Rivers, 1991. Report of the National Marine Fisheries Service to the U.S. Army Corps of Engineers, Walla Walla District, Walla Walla, Washington.

Achord, S., E. E. Hockersmith, B. P. Sandford, R. A. McNatt, B. E. Feist, and G. M. Matthews. 2003. Monitoring the migrations of wild Snake River spring/summer Chinook salmon smolts, 2002. Report of the National Marine Fisheries Service to the Bonneville Power Administration. Document 00005619-2 available at www.efw.bpa.gov/searchpublications (February 2009).

Achord, S., J. M. Hodge, B. P. Sandford, E. E. Hockersmith, K. W. McIntyre, N. N. Paasch, and J. G. Williams. 2005. Monitoring the migrations of wild Snake River spring/summer Chinook salmon smolts, 2004. Report of the National Marine Fisheries Service to the Bonneville Power Administration. Document 00005619-4 available at www.efw.bpa.gov/searchpublications (February 2009).

Achord, S., D. J. Kamikawa, B. P. Sandford, and G. M. Matthews. 1995a. Monitoring the migrations of wild Snake River spring/summer Chinook salmon smolts, 1993. Report of the National Marine Fisheries Service to the Bonneville Power Administration. Document D18800-2 available at www.efw.bpa.gov/searchpublications (February 2009).

Achord, S., D. J. Kamikawa, B. P. Sandford, and G. M. Matthews. 1995b. Monitoring the migrations of wild Snake River spring/summer Chinook salmon smolts, 1994. Report of the National Marine Fisheries Service to the Bonneville Power Administration. Document D18800-3 available at www.efw.bpa.gov/searchpublications (February 2009).

Achord, S., G. M. Matthews, O. W. Johnson, and D. M. Marsh. 1996b. Use of Passive Integrated Transponder (PIT) tags to monitor migration timing of Snake River Chinook salmon smolts. North American Journal of Fisheries Management 16:302-313.

Achord, S., G. M. Matthews, D. M. Marsh, B. P. Sandford, and D. J. Kamikawa. 1994. Monitoring the migrations of wild Snake River spring and summer Chinook salmon smolts, 1992. Report of the National Marine Fisheries Service to the Bonneville Power Administration. Document D18800-1 available at www.efw.bpa.gov/searchpublications (February 2009). 
Achord, S., R. A. McNatt, E. E. Hockersmith, B. P. Sandford, K. W. McIntyre, N. N. Paasch, J. G. Williams, and G. M. Matthews. 2004. Monitoring the migrations of wild Snake River spring/summer Chinook salmon smolts, 2003. Report of the National Marine Fisheries Service to the Bonneville Power Administration. Document 00005619-3 available at www.efw.bpa.gov/searchpublications (February 2009).

Achord, S., B. P. Sandford, E. E. Hockersmith, J. M. Hodge, K. W. McIntyre, N. N. Paasch, L. G. Crozier, and J. G. Williams. 2006. Monitoring the migrations of wild Snake River spring/summer Chinook salmon juveniles, 2004-2005. Report of the National Marine Fisheries Service to the Bonneville Power Administration. Document 00021961-1 available at www.efw.bpa.gov/searchpublications (February 2009).

Achord, S., B. P. Sandford, E. E. Hockersmith, K. W. McIntyre, N. N. Paasch, and J. G. Williams. 2007. Monitoring the migrations of wild Snake River spring/summer Chinook salmon juveniles, 2005-2006. Report of the National Marine Fisheries Service to the Bonneville Power Administration. Document 00021961-2 available at www.efw.bpa.gov/searchpublications (February 2009).

Achord, S., B. P. Sandford, E. E. Hockersmith, M. G. Nesbit, N. D. Dumdei, J. L. Lamb, K. W. McIntyre, N. N. Paasch, and J. G. Williams. 2008. Monitoring the migrations of wild Snake River spring/summer Chinook salmon juveniles, 20062007. Report to Bonneville Power Administration, Project 199102800, Contract 00031849. 92 p. Available on the Internet at www.efw.bpa.gov/searchpublications (February 2009).

Achord, S., R. W. Zabel, and B. P. Sandford. 2007. Migration timing, growth, and estimated parr-to-smolt survival rates of wild Snake River spring/summer Chinook salmon from the Salmon River basin, Idaho, to the lower Snake River. Transactions of the American Fisheries Society 136:142-154.

Downing, S. L., E. F. Prentice, B. W. Peterson, E. P. Nunnallee, and B. F. Jonasson. 2001. Development and evaluation of passive integrated transponder tag technology, annual report: 1999 to 2000. Report to Bonneville Power Administration, project 83-319, contract 307-0001. Available on the Internet at http://www.efw.bpa.gov/searchpublications (February 2009).

Efron, B., and R. J. Tibshirani. 1993. An introduction to the bootstrap. Chapman and Hall, Norwell, MA, 436 p.

Ledgerwood, R. D., B. A. Ryan, E. M. Dawley, E. P. Nunnallee, and J. W. Ferguson. 2004. A Surface Trawl to Detect Migrating Juvenile Salmonids Tagged with Passive Integrated Transponder tags. North American Journal of Fisheries Management 24:440-451. 
Matthews, G. M., J. R. Harmon, S. Achord, O. W. Johnson, and L. A. Kubin. 1990. Evaluation of transportation of juvenile salmonids and related research on the Snake and Columbia Rivers, 1989. Report to U.S. Army Corp of Engineers, Contract DACW68-84-H0034. 59 p. plus Appendix. Available from Northwest Fisheries Science Center, 2725 Montlake Blvd. E., Seattle WA 98112-2097.)

NWFSC (Northwest Fisheries Science Center). 2007. The baseline water quality environmental monitoring program. Online database available at http://webapps.nwfsc.noaa.gov/WaterQuality/

Petersen, R. G. 1985. Design and analysis of experiments. Marcel Dekker, New York, $429 \mathrm{p}$.

Prentice, E. F., T. A. Flagg, and C. S. McCutcheon. 1990. PIT-tag monitoring systems for hydroelectric dams and fish hatcheries. American Fisheries Society Symposium 7:323-334.

PTAGIS (PIT Tag Information System). 1996-present. PIT tag information system for the Columbia River Basin. Pacific States Marine Fisheries Commission. Portland, Oregon. Online database available at http://www.ptagis.org/ (March 2008).

Sandford, B. P., and S. G. Smith. 2002. Estimation of smolt-to-adult return percentages for Snake River Basin anadromous salmonids, 1990-1997. Journal of Agricultural Biological and Environmental Statistics 7(2):243-263. 


\section{APPENDIX}

Data Tables and Figures 
Appendix Table 1. Summary of numbers collected, tagged, released, and minimum, maximum, and mean lengths and weights of wild Chinook salmon parr, collected and PIT tagged in various Idaho streams, 2007.

\begin{tabular}{|c|c|c|c|c|c|c|c|c|c|c|c|}
\hline & & & & \multicolumn{4}{|c|}{ Collection } & \multicolumn{4}{|c|}{ Tagging and release } \\
\hline & \multicolumn{3}{|c|}{ Number of fish } & \multicolumn{2}{|c|}{ length (mm) } & \multicolumn{2}{|c|}{ weight (g) } & \multicolumn{2}{|c|}{ length (mm) } & \multicolumn{2}{|c|}{ weight $(\mathrm{g})$} \\
\hline & collected & tagged & released & range & mean & range & mean & range & mean & range & mean \\
\hline Bear Valley Creek & 539 & 515 & 514 & $51-87$ & 68.9 & $1.5-7.9$ & 4.2 & $56-58$ & 69.0 & $2-7.9$ & 4.2 \\
\hline Elk Creek & 850 & 500 & 500 & $53-144$ & 71.4 & $1.9-39.7$ & 4.9 & $56-85$ & 70.4 & $1.9-8.1$ & 4.4 \\
\hline Cape Horn Creek & 681 & 499 & 499 & $45-114$ & $64 . .4$ & $0.7-7.2$ & 3.4 & $56-86$ & 66.3 & $1-7.2$ & 3.5 \\
\hline Valley Creek & 2,923 & 2,525 & 2,524 & $40-134$ & 69.0 & $1.2-30.6$ & 4.6 & $56-105$ & 70.0 & 1.8 & 4.5 \\
\hline Camas Creek & 525 & 507 & 507 & $54-114$ & 69.0 & $2.2-12$ & 4.2 & $55-97$ & 69.0 & $2.1-12$ & 4.3 \\
\hline Herd Creek & 331 & 320 & 320 & $60-94$ & 79.1 & $4.4-11.3$ & 6.9 & $55-106$ & 65.1 & $2.5-18.9$ & 6.9 \\
\hline Big Creek (upper) & 647 & 630 & 628 & $53-113$ & 70.3 & $1.7-16.1$ & 4.5 & $56-92$ & 70.3 & $2.3-8.3$ & 4.5 \\
\hline Big Creek (lower) & 268 & 247 & 247 & $55-89$ & 75.7 & $2.1-.6$ & 5.3 & $57-89$ & 75.8 & $2.1-8.6$ & 5.4 \\
\hline Loon Creek & 293 & 276 & 276 & $48-133$ & 68.4 & $1.3-7.7$ & 3.7 & $55-85$ & 69.0 & $2.2-7.7$ & 3.8 \\
\hline Marsh Creek & 554 & 499 & 499 & $51-86$ & 70.5 & $1-8.9$ & 4.4 & $56-86$ & 70.8 & $1-8.9$ & 4.5 \\
\hline Sulphur Creek & 396 & 375 & 375 & $50-136$ & 67.5 & 1.9 & 4.3 & $56-86$ & 68.0 & $1.9-8.1$ & 4.2 \\
\hline Lake Creek & 587 & 501 & 501 & $48-111$ & 66.1 & $2-18.9$ & 4.2 & $55-106$ & 65.1 & $2.5-18.9$ & 3.9 \\
\hline Total or mean & 8,594 & 7,394 & 7,390 & $40-144$ & 69.4 & $0.7-39.7$ & 4.5 & $55-106$ & 69.8 & $1-18.9$ & 4.4 \\
\hline
\end{tabular}


Appendix Table 2a. Summary of tagging dates, start tagging times (PST) and temperatures $\left({ }^{\circ} \mathrm{C}\right)$, release dates, times, and temperatures, methods of capture, distance (in kilometers) from the mouth of the stream to the release point, number released (in 2007), and number/percent of first-time detections (unadjusted) for each tag group at seven downstream dams and the PIT-tag trawl at the mouth of the Columbia River during 2008.

\begin{tabular}{|c|c|c|c|c|c|c|c|c|c|c|c|}
\hline \multirow[b]{2}{*}{ Group } & \multicolumn{3}{|c|}{ Tagging } & \multirow{2}{*}{$\begin{array}{l}\text { Capture } \\
\text { method }\end{array}$} & \multicolumn{5}{|c|}{ Release } & \multicolumn{2}{|c|}{ Detection } \\
\hline & date & time & temp $\left({ }^{\circ} \mathrm{C}\right)$ & & date & time & temp $\left({ }^{\circ} \mathrm{C}\right)$ & river $\mathrm{km}$ & $\mathrm{n}$ & $\mathrm{n}$ & $(\%)$ \\
\hline \multicolumn{12}{|c|}{ Bear Valley Creek } \\
\hline SA07207.BV1 & $7 / 26 / 07$ & $06: 10$ & 15.0 & SHOCK & $7 / 27 / 07$ & 05:30 & 13.0 & 09 & 108 & 19 & 17.6 \\
\hline SA07207.BV2 & $7 / 26 / 07$ & $08: 10$ & 14.5 & SHOCK & $7 / 26 / 06$ & $11: 15$ & 15.0 & 10 & 159 & 28 & 17.6 \\
\hline SA07208.BV1 & $7 / 27 / 07$ & 07:03 & 13.0 & SHOCK & $7 / 27 / 07$ & $09: 45$ & 14.0 & 13 & 105 & 16 & 15.2 \\
\hline SA07208.BV2 & $7 / 27 / 07$ & 08:21 & 14.0 & SHOCK & $7 / 28 / 07$ & $06: 45$ & 13.0 & 14 & 149 & 18 & 12.1 \\
\hline \multicolumn{12}{|l|}{ Elk Creek } \\
\hline SA07209.EC1 & $7 / 28 / 07$ & $05: 27$ & 13.0 & BSEINE & $7 / 29 / 07$ & 07:00 & 12.0 & 01 & 113 & 21 & 18.6 \\
\hline SA07209.EC2 & $7 / 28 / 07$ & $06: 44$ & 13.0 & BSEINE & $7 / 28 / 07$ & $10: 00$ & 15.0 & 01 & 254 & 51 & 20.1 \\
\hline SA07209.EC3 & $7 / 28 / 07$ & $07: 46$ & 13.0 & SHOCK & $7 / 28 / 07$ & $10: 10$ & 15.0 & 02 & 145 & 31 & 21.4 \\
\hline \multicolumn{12}{|l|}{ Marsh Creek } \\
\hline SA07211.MC1 & $7 / 30 / 07$ & $07: 38$ & 09.2 & SHOCK & $7 / 31 / 07$ & 05:00 & 09.0 & 12 & 122 & 24 & 19.7 \\
\hline SA07211.MC2 & $7 / 30 / 07$ & $09: 30$ & 11.0 & SHOCK & $7 / 30 / 07$ & $12: 00$ & 16.0 & 13 & 316 & 53 & 16.8 \\
\hline SA07212.MC1 & $7 / 31 / 07$ & $07: 30$ & 09.0 & SHOCK & $7 / 31 / 07$ & 08:00 & 09.3 & 13 & 65 & 7 & 10.8 \\
\hline \multicolumn{12}{|c|}{ Cape Horn Creek } \\
\hline SA07212.CH1 & $7 / 31 / 07$ & 08:20 & 09.3 & SHOCK & $8 / 01 / 07$ & 05:00 & 07.7 & 01 & 130 & 22 & 16.9 \\
\hline SA07212.CH2 & $7 / 31 / 07$ & $09: 32$ & 10.5 & SHOCK & $7 / 31 / 07$ & $11: 30$ & 16.0 & 02 & 370 & 79 & 21.4 \\
\hline \multicolumn{12}{|l|}{ Sulpur Creek } \\
\hline SA07212.SU1 & $7 / 31 / 07$ & $06: 44$ & 12.5 & SHOCK & $8 / 01 / 07$ & $04: 45$ & 11.6 & 05 & 92 & 11 & 12.0 \\
\hline SA07212.SU2 & $7 / 31 / 07$ & $09: 22$ & 13.0 & SHOCK & $8 / 01 / 07$ & 05:00 & 11.6 & 06 & 71 & 12 & 16.9 \\
\hline SA07213.SU1 & $8 / 01 / 07$ & 07:05 & 11.5 & SHOCK & $8 / 01 / 07$ & $11: 20$ & 14.0 & 08 & 223 & 50 & 22.4 \\
\hline \multicolumn{12}{|l|}{ Valley Creek } \\
\hline SA07213.VC1 & $8 / 01 / 07$ & $07: 44$ & 11.0 & SHOCK & $8 / 02 / 07$ & 07:00 & 11.0 & 05 & 110 & 12 & 10.9 \\
\hline SA07213.VC2 & $8 / 01 / 07$ & $08: 34$ & 12.0 & SHOCK & $8 / 01 / 07$ & $10: 10$ & 16.0 & 05 & 277 & 20 & 7.2 \\
\hline
\end{tabular}


Appendix Table 2a. Continued.

\begin{tabular}{|c|c|c|c|c|c|c|c|c|c|c|c|}
\hline \multirow[b]{2}{*}{ Group } & \multicolumn{3}{|c|}{ Tagging } & \multirow{2}{*}{$\begin{array}{l}\text { Capture } \\
\text { method }\end{array}$} & \multicolumn{5}{|c|}{ Release } & \multicolumn{2}{|c|}{ Detection } \\
\hline & date & time & temp $\left({ }^{\circ} \mathrm{C}\right)$ & & date & time & temp $\left({ }^{\circ} \mathrm{C}\right)$ & river $\mathrm{km}$ & $\mathrm{n}$ & $\mathrm{n}$ & $(\%)$ \\
\hline \multicolumn{12}{|c|}{ Valley Creek (continued) } \\
\hline SA07214.VC1 & $8 / 02 / 07$ & $07: 21$ & 11.3 & SHOCK & $8 / 02 / 07$ & $10: 10$ & 16.0 & 08 & 384 & 44 & 11.5 \\
\hline SA07215.VC1 & $8 / 03 / 07$ & $06: 30$ & 12.0 & SHOCK & $8 / 03 / 07$ & $11: 30$ & 19.0 & 10 & 1126 & 87 & 7.7 \\
\hline SA07216.VC1 & $8 / 04 / 07$ & $07: 25$ & 10.7 & SHOCK & $8 / 04 / 07$ & $11: 00$ & 16.0 & 12 & 921 & 64 & 6.9 \\
\hline \multicolumn{12}{|l|}{ Herd Creek } \\
\hline SA07218.HC1 & $8 / 06 / 07$ & 06:19 & 08.5 & SHOCK & $8 / 06 / 07$ & $11: 00$ & 13.5 & 02 & 321 & 83 & 25.9 \\
\hline \multicolumn{12}{|l|}{ Loon Creek } \\
\hline SA07220.LN1 & $8 / 08 / 07$ & $05: 28$ & 09.0 & SHOCK & $8 / 09 / 07$ & $04: 30$ & 09.5 & 34 & 128 & 29 & 22.7 \\
\hline SA07220.LN2 & $8 / 08 / 07$ & 09:40 & 09.0 & SHOCK & $8 / 08 / 07$ & $10: 00$ & 11.5 & 35 & 102 & 26 & 25.5 \\
\hline SA07221.LN1 & $8 / 09 / 07$ & $06: 21$ & 09.5 & SHOCK & $8 / 09 / 07$ & 08:30 & 10.0 & 36 & 70 & 16 & 22.9 \\
\hline \multicolumn{12}{|l|}{ Camas Creek } \\
\hline SA07220.CA1 & $8 / 08 / 07$ & $07: 10$ & 08.6 & SHOCK & $8 / 08 / 07$ & 06:00 & 09.5 & 22 & 108 & 17 & 15.7 \\
\hline SA07220.CA2 & $8 / 08 / 07$ & $08: 27$ & 09.0 & SHOCK & $8 / 08 / 07$ & $10: 30$ & 13.0 & 23 & 244 & 40 & 16.4 \\
\hline SA07221.CA1 & $8 / 09 / 07$ & $07: 33$ & 09.5 & SHOCK & $8 / 09 / 07$ & $10: 00$ & 12.0 & 24 & 158 & 38 & 24.0 \\
\hline \multicolumn{12}{|l|}{ Lake Creek } \\
\hline SA07224.LC1 & $8 / 12 / 07$ & $07: 35$ & 08.5 & SHOCK & $8 / 12 / 07$ & $10: 15$ & 13.0 & 02 & 584 & 71 & 12.2 \\
\hline \multicolumn{12}{|c|}{ Big Creek (upper) } \\
\hline SA07235.BC1 & $8 / 23 / 07$ & 09:06 & 07.7 & SHOCK & $8 / 24 / 07$ & $05: 30$ & 07.0 & 60 & 287 & 62 & 21.6 \\
\hline SA07236.BC1 & $8 / 24 / 07$ & 08:29 & 07.0 & SHOCK & $8 / 24 / 07$ & $10: 15$ & 11.0 & 61 & 348 & 77 & 22.1 \\
\hline \multicolumn{12}{|c|}{ Big Creek (lower) } \\
\hline SA07225.LB1 & $8 / 13 / 07$ & $06: 58$ & 11.0 & SHOCK & $8 / 14 / 07$ & 05:00 & 11.0 & 08 & 98 & 20 & 20.4 \\
\hline SA07225.LB2 & $8 / 13 / 07$ & $10: 25$ & 11.5 & SHOCK & $8 / 13 / 07$ & $11: 00$ & 13.5 & 09 & 72 & 12 & 16.7 \\
\hline SA07226.LB1 & $8 / 13 / 07$ & $10: 25$ & 11.5 & SHOCK & $8 / 13 / 07$ & $11: 00$ & 13.5 & 09 & 85 & 15 & 17.6 \\
\hline
\end{tabular}


Appendix Table 2b. Universal Transverse Mercator grid coordinates of Global Positioning System that identify sampling areas at the beginning and end of daily collections in streams for each collection crew in 2007.

\begin{tabular}{|c|c|c|c|c|c|}
\hline \multirow{3}{*}{$\begin{array}{l}\text { Streams and } \\
\text { dates }\end{array}$} & \multirow{3}{*}{$\begin{array}{l}\text { Section } \\
\text { covered }\end{array}$} & \multicolumn{4}{|c|}{ UTM } \\
\hline & & \multicolumn{2}{|c|}{ Start } & \multicolumn{2}{|c|}{ End } \\
\hline & & northing & easting & northing & easting \\
\hline \multicolumn{6}{|c|}{ Bear Valley Creek } \\
\hline $7 / 26 / 2007$ & Left bank & 4920479 & $11 \mathrm{~T} 0633052$ & 4920685 & $11 \mathrm{~T} 0631916$ \\
\hline $7 / 26 / 2007$ & Left bank & 4920786 & $11 \mathrm{~T} 0633234$ & 4920642 & $11 \mathrm{~T} 0631783$ \\
\hline $7 / 26 / 2007$ & Right bank & 4920606 & $11 \mathrm{~T} 0633094$ & 4920621 & $11 \mathrm{~T} 0631687$ \\
\hline $7 / 27 / 2007$ & Right bank & 4919345 & $11 \mathrm{~T} 0630208$ & 4918492 & $11 \mathrm{~T} 0629827$ \\
\hline $7 / 27 / 2007$ & Right bank & 4919094 & $11 \mathrm{~T} 0630152$ & 4918485 & $11 \mathrm{~T} 0629736$ \\
\hline $7 / 27 / 2007$ & Left bank & 4919659 & $11 \mathrm{~T} 0630198$ & 4918490 & $11 \mathrm{~T} 0629879$ \\
\hline Elk Creek & Entire stream & & & & \\
\hline $7 / 28 / 2007$ & (Seine Net) & 4918799 & $11 \mathrm{~T} 0629516$ & 4918766 & $11 \mathrm{~T} 0629431$ \\
\hline $7 / 28 / 2007$ & Right bank & 4918761 & $11 \mathrm{~T} 0629430$ & 4918702 & $11 \mathrm{~T} 0628788$ \\
\hline $7 / 28 / 2007$ & Left bank & 4918550 & $11 \mathrm{~T} 0629230$ & 4918699 & $11 \mathrm{~T} 0628773$ \\
\hline $7 / 28 / 2007$ & Left bank & 4918752 & $11 \mathrm{~T} 0629439$ & 4918702 & $11 \mathrm{~T} 0628788$ \\
\hline \multicolumn{6}{|c|}{ Marsh Creek } \\
\hline $7 / 30 / 2007$ & Left bank & 4917107 & $11 \mathrm{~T} 0646315$ & 4916474 & $11 \mathrm{~T} 0646864$ \\
\hline $7 / 30 / 2007$ & Right bank & 4917104 & $11 \mathrm{~T} 0646291$ & 4916476 & $11 \mathrm{~T} 0646863$ \\
\hline $7 / 30 / 2007$ & Right bank & 4916474 & $11 \mathrm{~T} 0646864$ & 4916316 & $11 \mathrm{~T} 0645347$ \\
\hline \multicolumn{6}{|c|}{ Cape Horn Creek } \\
\hline $7 / 31 / 2007$ & Left bank & 4917439 & $11 \mathrm{~T} 0645789$ & 4916197 & $11 \mathrm{~T} 0645202$ \\
\hline $7 / 31 / 2007$ & Right bank & 4916197 & $11 \mathrm{~T} 0645729$ & 4916197 & $11 \mathrm{~T} 0645202$ \\
\hline \multicolumn{6}{|c|}{ Sulphur Creek } \\
\hline $7 / 31 / 2007$ & Left bank & 4933147 & $11 \mathrm{~T} 0631103$ & 4932431 & $11 \mathrm{~T} 0630030$ \\
\hline $7 / 31 / 2007$ & Right bank & 4933062 & $11 \mathrm{~T} 0631110$ & 4932431 & $11 \mathrm{~T} 0630030$ \\
\hline $8 / 1 / 2007$ & Right bank & 4932407 & $11 \mathrm{~T} 0629941$ & 4932407 & $11 \mathrm{~T} 0629092$ \\
\hline $8 / 1 / 2007$ & Left bank & 4932416 & $11 \mathrm{~T} 0629962$ & 4932417 & $11 \mathrm{~T} 0628968$ \\
\hline \multicolumn{6}{|l|}{ Valley Creek } \\
\hline $8 / 1 / 2007$ & Left bank & 4899456 & $11 \mathrm{~T} 0661374$ & 4899940 & $11 \mathrm{~T} 0660130$ \\
\hline $8 / 1 / 2007$ & Right bank & 4899456 & $11 \mathrm{~T} 0661310$ & 4899940 & $11 \mathrm{~T} 0660130$ \\
\hline $8 / 2 / 2007$ & Left bank & 4900111 & $11 \mathrm{~T} 0659942$ & 4901634 & $11 \mathrm{~T} 0659407$ \\
\hline $8 / 2 / 2007$ & Right bank & 4900111 & $11 \mathrm{~T} 0659942$ & 4901648 & $11 \mathrm{~T} 0659419$ \\
\hline $8 / 3 / 2007$ & Left bank & 4901931 & $11 \mathrm{~T} 0659273$ & 4902905 & $11 \mathrm{~T} 0659223$ \\
\hline $8 / 3 / 2007$ & Right bank & 4901804 & $11 \mathrm{~T} 0659319$ & 4903335 & $11 \mathrm{~T} 0659136$ \\
\hline
\end{tabular}


Appendix Table 2b. Continued

\begin{tabular}{|c|c|c|c|c|c|}
\hline \multirow{3}{*}{$\begin{array}{l}\text { Streams and } \\
\text { dates }\end{array}$} & \multirow{3}{*}{$\begin{array}{l}\text { Section } \\
\text { covered }\end{array}$} & \multicolumn{4}{|c|}{ UTM } \\
\hline & & \multicolumn{2}{|c|}{ Start } & \multicolumn{2}{|c|}{ End } \\
\hline & & northing & easting & northing & easting \\
\hline \multicolumn{6}{|c|}{ Valley Creek (continued) } \\
\hline $8 / 3 / 2007$ & Right bank & 4901939 & $11 \mathrm{~T} 0659276$ & 4902830 & $11 \mathrm{~T} 0659221$ \\
\hline $8 / 3 / 2007$ & Left bank & 4902034 & $11 \mathrm{~T} 0659263$ & 4903433 & $11 \mathrm{~T} 0659263$ \\
\hline $8 / 4 / 2007$ & Left bank & 4903803 & $11 \mathrm{~T} 0659019$ & 4905100 & $11 \mathrm{~T} 0658649$ \\
\hline $8 / 4 / 2007$ & Right bank & 4903770 & $11 \mathrm{~T} 0659021$ & 4905084 & $11 \mathrm{~T} 0658667$ \\
\hline $8 / 4 / 2007$ & Right bank & 4904094 & $11 \mathrm{~T} 0658852$ & 4904843 & $11 \mathrm{~T} 0658903$ \\
\hline $8 / 4 / 2007$ & Left bank & 4904086 & $11 \mathrm{~T} 0658851$ & 4904701 & $11 \mathrm{~T} 0658827$ \\
\hline \multicolumn{6}{|l|}{ Herd Creek } \\
\hline $8 / 6 / 2007$ & Left bank & 4892106 & $11 \mathrm{~T} 0716231$ & 4890333 & $11 \mathrm{~T} 0717800$ \\
\hline $8 / 6 / 2007$ & Left bank & 4891703 & $11 \mathrm{~T} 0717487$ & 4890852 & $11 \mathrm{~T} 0717487$ \\
\hline $8 / 6 / 2007$ & Right bank & 4889982 & $11 \mathrm{~T} 0717936$ & 4889780 & $11 \mathrm{~T} 0718985$ \\
\hline $8 / 6 / 2007$ & Right bank & 4890136 & $11 \mathrm{~T} 0716228$ & 4890136 & $11 \mathrm{~T} 0717900$ \\
\hline \multicolumn{6}{|l|}{ Loon Creek } \\
\hline $8 / 8 / 2007$ & Left bank & 4942164 & $11 \mathrm{~T} 0674877$ & 4941035 & $11 \mathrm{~T} 0674065$ \\
\hline $8 / 8 / 2007$ & Right bank & 4942081 & $11 \mathrm{~T} 0675030$ & 4942038 & $11 \mathrm{~T} 0674057$ \\
\hline $8 / 9 / 2007$ & Left bank & 4942164 & $11 \mathrm{~T} 0674877$ & 4940253 & $11 \mathrm{~T} 0673249$ \\
\hline $8 / 9 / 2007$ & Right bank & 4941038 & $11 \mathrm{~T} 0674057$ & 4940253 & $11 \mathrm{~T} 0673249$ \\
\hline \multicolumn{6}{|c|}{ Camas Creek } \\
\hline $8 / 8 / 2007$ & Left bank & 4968304 & $11 \mathrm{~T} 0696363$ & 4967179 & $11 \mathrm{~T} 0697305$ \\
\hline $8 / 8 / 2007$ & Right bank & 4968304 & $11 \mathrm{~T} 0696363$ & 4967179 & $11 \mathrm{~T} 0697305$ \\
\hline $8 / 9 / 2007$ & Left bank & 4964179 & $11 \mathrm{~T} 0697305$ & 4966239 & $11 \mathrm{~T} 0697880$ \\
\hline $8 / 9 / 2007$ & Right bank & 4964179 & $11 \mathrm{~T} 0697305$ & 4966239 & $11 \mathrm{~T} 0697880$ \\
\hline \multicolumn{6}{|c|}{ Big Creek-Lower } \\
\hline $8 / 13 / 2007$ & Left bank & 4996504 & $11 \mathrm{~T} 0670255$ & 4996667 & $11 \mathrm{~T} 0668863$ \\
\hline $8 / 13 / 2007$ & Right bank & 4996504 & $11 \mathrm{~T} 0670255$ & 4996684 & $11 \mathrm{~T} 0668905$ \\
\hline $8 / 14 / 2007$ & Right bank & 4996697 & $11 \mathrm{~T} 0668872$ & 4996911 & $11 \mathrm{~T} 0667637$ \\
\hline $8 / 14 / 2007$ & Left bank & 4996697 & $11 \mathrm{~T} 0668863$ & 4996911 & $11 \mathrm{~T} 0667637$ \\
\hline \multicolumn{6}{|l|}{ Lake Creek } \\
\hline $8 / 12 / 2007$ & & --- & --- & 5012786 & $11 \mathrm{~T} 058587$ \\
\hline \multicolumn{6}{|c|}{ Big Creek-Upper } \\
\hline $8 / 23 / 2007$ & Left bank & 4996707 & $11 \mathrm{~T} 0631595$ & 499556 & $11 \mathrm{~T} 0631322$ \\
\hline $8 / 23 / 2007$ & Right bank & 4996707 & $11 \mathrm{~T} 0631595$ & 499556 & $11 \mathrm{~T} 0631322$ \\
\hline $8 / 23 / 2007$ & Right bank & 4995560 & $11 \mathrm{~T} 0631322$ & 4994791 & $11 \mathrm{~T} 0631277$ \\
\hline $8 / 23 / 2007$ & Left bank & 4995560 & $11 \mathrm{~T} 0631322$ & 4994791 & $11 \mathrm{~T} 0631277$ \\
\hline
\end{tabular}


Appendix Table 3. Summary of observed total mortality for PIT-tagged wild Chinook salmon parr collected from Idaho streams during July and August 2007. Number rejected includes; fish too small to tag, precocious males, injured fish, fish collected for genetic evaluation, previously tagged fish, and in some cases extra collected fish. The portion of rejects that are precocious males are in parentheses. There was also one lost tag from Big Creek (upper).

\begin{tabular}{|c|c|c|c|c|c|c|c|c|}
\hline \multirow[b]{2}{*}{ Stream } & \multirow[b]{2}{*}{$\begin{array}{l}\text { Number } \\
\text { collected }\end{array}$} & \multirow[b]{2}{*}{$\begin{array}{c}\text { Number } \\
\text { tagged }\end{array}$} & \multirow[b]{2}{*}{$\begin{array}{l}\text { Number } \\
\text { rejected }\end{array}$} & \multirow[b]{2}{*}{$\begin{array}{c}\text { Percent } \\
\text { rejected } \\
(\%)\end{array}$} & \multicolumn{2}{|c|}{$\begin{array}{l}\text { Observed } \\
\text { mortality }\end{array}$} & \multirow[b]{2}{*}{$\begin{array}{c}\text { Total } \\
\text { number }\end{array}$} & \multirow[b]{2}{*}{$(\%)$} \\
\hline & & & & & $\begin{array}{l}\text { Collection } \\
\text { and } \\
\text { handling }\end{array}$ & $\begin{array}{l}\text { Tagging } \\
\text { delayed }\end{array}$ & & \\
\hline Bear Valley $\mathrm{Cr}$ & 539 & 515 & 24 & 4.4 & 17 & 1 & 18 & 3.3 \\
\hline Elk Creek & 850 & 500 & $350(9)$ & 41.2 & 3 & 0 & 3 & 0.4 \\
\hline Cape Horn Cr & 681 & 499 & $182(7)$ & 26.7 & 9 & 0 & 9 & 1.3 \\
\hline Valley Creek & 2,923 & 2525 & $398(25)$ & 13.6 & $35(1)$ & 1 & $36(1)$ & 1.2 \\
\hline Camas Creek & 525 & 507 & $18(1)$ & 3.4 & 11 & 0 & 11 & 2.1 \\
\hline Herd Creek & 331 & 320 & 11 & 3.3 & 10 & 0 & 10 & 3.0 \\
\hline Big Cr (upper) & 647 & 630 & $17(1)$ & 2.6 & 7 & 1 & 8 & 1.2 \\
\hline Big Cr (lower) & 268 & 247 & 21 & 7.8 & 5 & 0 & 5 & 0.8 \\
\hline Loon Creek & 293 & 276 & $17(1)$ & 5.8 & $3(1)$ & 0 & $3(1)$ & 1.0 \\
\hline Marsh Creek & 554 & 499 & 55 & 9.9 & 4 & 0 & 4 & 0.7 \\
\hline Suphur Creek & 396 & 375 & $21(2)$ & 5.3 & 10 & 0 & 10 & 2.5 \\
\hline Lake Creek & 587 & 501 & $86(36)$ & 15 & 3 & 0 & 3 & 0.5 \\
\hline Totals or Average & 8,594 & 7,394 & $1,200(82)$ & 14.0 & $117(2)$ & 3 & $120(2)$ & 1.4 \\
\hline
\end{tabular}


Appendix Table 4a. Accumulated and 2008 passage dates at Lower Granite Dam for PIT-tagged wild spring/summer Chinook salmon smolts from streams in Idaho.

\begin{tabular}{|c|c|c|c|c|}
\hline \multirow[b]{2}{*}{ Year } & \multicolumn{4}{|c|}{ Percentile passage dates at Lower Granite Dam } \\
\hline & 10th & 50 th & 90th & Range \\
\hline \multicolumn{5}{|l|}{ Bear Valley Creek } \\
\hline $1990^{\mathrm{a}}$ & 19 April & 05 May & 31 May & 11 April-18 July \\
\hline 1991 & 03 May & 20 May & 12 June & 18 April-23 June \\
\hline 1992 & 15 April & 02 May & 24 May & 07 April-28 June \\
\hline 1993 & 29 April & 16 May & 22 June & 22 April-27 July \\
\hline 1994 & 22 April & 06 May & 29 May & 16 April-15 July \\
\hline 1995 & 28 April & 18 May & 12 June & 13 April-20 July \\
\hline $1996^{\mathrm{a}} 1997^{\mathrm{a}}$ & --- & --- & --- & -- \\
\hline 1998 & 25 April & 06 May & 23 May & 31 March-25 June \\
\hline 1999 & 23 April & 03 May & 07 June & 20 April-21 June \\
\hline 2000 & 18 April & 07 May & 02 June & 14 April-02 July \\
\hline 2001 & 08 May & 16 May & 28 May & 26 April-17 June \\
\hline 2002 & 16 April & 04 May & 31 May & 12 April-26 June \\
\hline 2003 & 14 April & 05 May & 28 May & 12 April-14 June \\
\hline 2004 & 15 April & 07 May & 28 May & 13 April-05 July \\
\hline 2005 & 20 April & 05 May & 23 May & 20 April-10 June \\
\hline 2006 & 13 April & 01 May & 19 May & 11 April-20 May \\
\hline 2007 & 18 April & 03 May & 13 May & 08 April-24 May \\
\hline 2008 & 30 April & 14 May & 27 May & 24 April-10 June \\
\hline \multicolumn{5}{|l|}{ Elk Creek } \\
\hline 1991 & 03 May & 20 May & 16 June & 25 April-24 June \\
\hline 1992 & 11 April & 30 April & 28 May & 05 April-17 July \\
\hline 1993 & 02 May & 16 May & 11 June & 21 April-26 June \\
\hline 1994 & 23 April & 04 May & 21 May & 18 April-09 July \\
\hline 1995 & 18 April & 11 May & 05 June & 10 April-09 July \\
\hline $1990^{\mathrm{a}} 1996^{\mathrm{a}} 1997^{\mathrm{a}}$ & --- & --- & --- & --- \\
\hline 1998 & 07 April & 02 May & 15 May & 04 April-21 June \\
\hline 1999 & 21 April & 03 May & 27 May & 01 April-08 July \\
\hline 2000 & 15 April & 28 April & 19 May & 13 April-28 May \\
\hline 2001 & 30 April & 11 May & 27 May & 30 April-27 May \\
\hline 2002 & 16 April & 29 April & 02 June & 13 April-05 July \\
\hline 2003 & 20 April & 06 May & 29 May & 31 March-30 May \\
\hline 2004 & 18 April & 08 May & 04 July & 14 April-12 July \\
\hline 2005 & 27 April & 11 May & 29 May & 18 April-12 June \\
\hline 2006 & 15 April & 27 April & 26 May & 06 April-11 June \\
\hline 2007 & 16 April & 02 May & 14 May & 14 April-31 May \\
\hline 2008 & 02 May & 11 May & 23 May & 25 April- 16 June \\
\hline \multicolumn{5}{|l|}{ Sulphur Creek } \\
\hline 1990 & 18 April & 30 April & 31 May & 11 April-27 June \\
\hline $1991^{\mathrm{a}}$ & --- & --- & --- & -- \\
\hline 1992 & 16 April & 03 May & 23 May & 10 April-01 June \\
\hline 1993 & 28 April & 16 May & 12 June & 24 April-28 June \\
\hline $1994^{\mathrm{a}}$ & --- & --- & --- & -- \\
\hline 1995 & 02 May & 23 May & 09 June & 11 April-09 July \\
\hline $1996^{\mathrm{a}}-1999^{\mathrm{a}}$ & --- & --- & --- & --- \\
\hline
\end{tabular}


Appendix Table 4a. Continued.

\begin{tabular}{|c|c|c|c|c|}
\hline \multirow[b]{2}{*}{ Year } & \multicolumn{4}{|c|}{ Percentile passage dates at Lower Granite Dam } \\
\hline & 10th & 50th & 90th & Range \\
\hline \multicolumn{5}{|c|}{ Sulphur Creek (Continued) } \\
\hline 2000 & 15 April & 07 May & 24 May & 12 April-30 May \\
\hline $2001-2002^{\mathrm{a}} \mathbf{2 0 0 7}^{\mathrm{a}}$ & --- & --- & --- & --- \\
\hline 2003 & 02 May & 25 May & 08 May & 22 April-24 June \\
\hline 2004 & 10 April & 25 April & 11 May & 02 April-24 May \\
\hline 2005 & 01 May & 07 May & 22 May & 22 April-05 June \\
\hline 2006 & 11 April & 28 April & 17 May & 11 April- 17 May \\
\hline 2008 & 03 May & 12 May & 02 June & 27 April-04 June \\
\hline \multicolumn{5}{|l|}{ Cape Horn Creek } \\
\hline $1990^{\mathrm{a}} 1996^{\mathrm{a}}-1998^{\mathrm{a}}$ & --- & --- & --- & --- \\
\hline 1991 & 24 April & 16 May & 28 May & 19 April-06 June \\
\hline 1992 & 12 April & 28 April & 30 May & 10 April-01 June \\
\hline 1993 & 08 May & 19 May & 26 June & 05 May-01 July \\
\hline $1994^{\mathrm{a}}$ & --- & --- & --- & --- \\
\hline 1995 & 29 April & 14 May & 19 June & 14 April-28 July \\
\hline 1999 & 29 April & 22 May & 29 May & 25 April-12 June \\
\hline 2000 & 01 May & 24 May & 01 June & 20 April-09 July \\
\hline $2001^{\mathrm{a}} 2002^{\mathrm{a}}$ & --- & --- & --- & --- \\
\hline 2003 & 21 April & 17 May & 01 June & 15 April-18 June \\
\hline 2004 & 15 April & 04 May & 24 May & 14 April-28 May \\
\hline 2005 & 29 April & 09 May & 24 May & 11 April-29 May \\
\hline 2006 & 23 April & 30 April & 14 June & 22 April-14 June \\
\hline 2007 & 13 April & 06 May & 19 May & 09 April-20 May \\
\hline 2008 & 03 May & 18 May & 23 May & 25 April-03 June \\
\hline \multicolumn{5}{|l|}{ Camas Creek } \\
\hline 1993 & 03 May & 16 May & 27 May & 24 April-24 June \\
\hline 1994 & 30 April & 15 May & 26 May & 24 April-11 July \\
\hline 1995 & 27 April & 12 May & 05 June & 17 April-11 June \\
\hline $1996^{\mathrm{a}}$ & --- & --- & --- & --- \\
\hline $1997^{\mathrm{a}} 1998^{\mathrm{a}} 1999^{\mathrm{a}}$ & --- & --- & --- & --- \\
\hline 2000 & 26 April & 25 May & 02 June & 13 April-24 June \\
\hline $2001^{\mathrm{a}} 2002^{\mathrm{a}}$ & --- & --- & --- & --- \\
\hline 2003 & 02 May & 24 May & 30 May & 26 April-06 June \\
\hline 2004 & 18 April & 08 May & 24 May & 16 April-04 June \\
\hline 2005 & 29 April & 07 May & 28 May & 12 April-19 June \\
\hline 2006 & 20 April & 30 April & 17 May & 20 April-03 June \\
\hline 2007 & 23 April & 06 May & 16 May & 19 April-19 May \\
\hline 2008 & 05 May & 14 May & 21 May & 27 April-31 May \\
\hline \multicolumn{5}{|l|}{ Marsh Creek } \\
\hline 1990 & 17 April & 29 April & 31 May & 09 April-01 July \\
\hline 1991 & 26 April & 20 May & 09 June & 17 April-18 June \\
\hline 1992 & 17 April & 07 May & 02 June & 10 April-13 July \\
\hline 1993 & 29 April & 15 May & 27 May & 24 April-10 August \\
\hline 1994 & 23 April & 04 May & 18 May & 16 April-08 August \\
\hline
\end{tabular}


Appendix Table 4a. Continued.

\begin{tabular}{|c|c|c|c|c|}
\hline \multirow[b]{2}{*}{ Year } & \multicolumn{4}{|c|}{ Percentile passage dates at Lower Granite Dam } \\
\hline & 10th & 50th & 90th & Range \\
\hline \multicolumn{5}{|c|}{ Marsh Creek (Continued) } \\
\hline 1995 & 17 April & 09 May & 24 May & 11 April-08 July \\
\hline $1996^{\mathrm{a}}$ & --- & --- & --- & -- \\
\hline $1997^{\mathrm{a}}$ & --- & --- & --- & --- \\
\hline $1998^{\mathrm{a}}$ & --- & --- & --- & --- \\
\hline 1999 & 21 April & 01 May & 25 May & 11 April-13 June \\
\hline 2000 & 21 April & 28 April & 27 May & 14 April-16 June \\
\hline $2001^{\mathrm{a}}$ & --- & --- & --- & --- \\
\hline 2002 & 18 April & 04 May & 23 May & 14 April-26 May \\
\hline 2003 & 14 April & 05 May & 29 May & 03 April-09 June \\
\hline 2004 & 16 April & 28 April & 10 May & 03 April-30 May \\
\hline 2005 & 27 April & 06 May & 18 May & 22 April-04 June \\
\hline 2006 & 12 April & 30 April & 18 May & 11 April-03 June \\
\hline $2007^{\mathrm{a}}$ & --- & --- & --- & --- \\
\hline 2008 & 29 April & 07 May & 18 May & 24 April-20 May \\
\hline \multicolumn{5}{|l|}{ Valley Creek } \\
\hline 1989 & 24 April & 14 May & 12 June & 09 April-17 June \\
\hline 1990 & 16 April & 08 May & 05 June & 12 April-29 June \\
\hline 1991 & 11 May & 20 May & 20 June & 21 April-13 July \\
\hline 1992 & 15 April & 30 April & 27 May & 13 April-04 June \\
\hline 1993 & 30 April & 16 May & 02 June & 24 April-06 June \\
\hline 1994 & 24 April & 04 May & 03 June & 22 April-09 June \\
\hline 1995 & 04 May & 02 June & 08 July & 22 April-18 July \\
\hline $1996^{\mathrm{a}} 1997^{\mathrm{a}} 1998^{\mathrm{a}}$ & --- & --- & --- & -- \\
\hline 1999 & 24 April & 13 May & 12 June & 19 April-01 July \\
\hline 2000 & 20 April & 12 May & 29 May & 13 April-14 July \\
\hline 2001 & 10 May & 19 May & 01 June & 28 April-03 July \\
\hline 2002 & 24 April & 20 May & 03 June & 19 April-19 June \\
\hline 2003 & 14 April & 17 May & 28 May & 01 April-31 May \\
\hline 2004 & 25 April & 11 May & 26 May & 04 April-16 June \\
\hline 2005 & 27 April & 15 May & 08 June & 23 April-20 June \\
\hline 2006 & 30 April & 24 May & 15 June & 16 April-17 June \\
\hline 2007 & 20 April & 03 May & 20 May & 13 April-24 May \\
\hline 2008 & 28 April & 11 May & 26 May & 21 April-06 June \\
\hline \multicolumn{5}{|l|}{ Loon Creek } \\
\hline 1993 & 05 May & 12 May & 17 May & 03 May-5 June \\
\hline 1994 & 29 April & 10 May & 24 May & 22 April-07 June \\
\hline 1995 & 23 April & 11 May & 28 May & 13 April-07 June \\
\hline $1996^{\mathrm{a}} 1997^{\mathrm{a}} 1998^{\mathrm{a}}$ & --- & --- & --- & -- \\
\hline 1999 & 30 April & 18 May & 27 May & 22 April-16 June \\
\hline 2000 & 22 April & 08 May & 24 May & 14 April-01 June \\
\hline $2001^{\mathrm{a}} 2002^{\mathrm{a}} 2007^{\mathrm{a}}$ & --- & --- & --- & -- \\
\hline 2003 & 30 April & 17 May & 28 May & 21 April-30 May \\
\hline 2004 & 23 April & 05 May & 15 May & 15 April-26 May \\
\hline 2005 & 04 May & 10 May & 24 May & 20 April-03 June \\
\hline
\end{tabular}


Appendix Table 4a. Continued.

\begin{tabular}{|c|c|c|c|c|}
\hline \multirow[b]{2}{*}{ Year } & \multicolumn{4}{|c|}{ Percentile passage dates at Lower Granite Dam } \\
\hline & 10th & 50 th & 90th & Range \\
\hline \multicolumn{5}{|c|}{ Loon Creek (Continued) } \\
\hline 2006 & 20 April & 02 May & 19 May & 10 April- 21 May \\
\hline 2008 & 07 May & 17 May & 26 May & 28 April-29 May \\
\hline
\end{tabular}

East Fork Salmon River discontinued--see previous reports (Achord et al. 2006-2008)

\begin{tabular}{|c|c|c|c|c|}
\hline \multicolumn{5}{|l|}{ Herd Creek } \\
\hline 1992 & 14 April & 20 April & 10 May & 13 April-18 May \\
\hline 1993 & 26 April & 30 April & 18 May & 26 April-31 May \\
\hline $1994^{\mathrm{b}}$ & --- & --- & --- & --- \\
\hline 1995 & 18 April & 03 May & 14 May & 11 April-28 May \\
\hline $1996^{\mathrm{a}} 1997^{\mathrm{a}} 1998^{\mathrm{a}}$ & --- & --- & --- & --- \\
\hline 1999 & 20 April & 29 April & 10 May & 30 March-20 May \\
\hline 2000 & 16 April & 25 April & 18 May & 14 April-19 May \\
\hline 2001 & 30 April & 04 May & 14 May & 28 April-07 June \\
\hline $2002^{\mathrm{b}}$ & --- & --- & --- & --- \\
\hline 2003 & 16 April & 03 May & 26 May & 06 April-29 May \\
\hline 2004 & 16 April & 30 April & 10 May & 12 April-21 June \\
\hline 2005 & 27 April & 07 May & 22 May & 20 April-13 June \\
\hline 2006 & 16 April & 25 April & 06 May & 10 April-16 May \\
\hline $2007^{\mathrm{b}}$ & --- & --- & --- & --- \\
\hline 2008 & 29 April & 10 May & 19 May & 24 April-23 May \\
\hline \multicolumn{5}{|c|}{ South Fork Salmon River } \\
\hline 1989 & 25 April & 13 May & 14 June & 16 April-20 June \\
\hline $1990^{\mathrm{a}}$ & --- & --- & --- & --- \\
\hline 1991 & 20 April & 16 May & 10 June & 17 April-13 July \\
\hline 1992 & 14 April & 29 April & 27 May & 07 April-27 July \\
\hline 1993 & 29 April & 16 May & 02 June & 26 April-28 June \\
\hline 1994 & 27 April & 15 May & 28 June & 22 April-09 July \\
\hline 1995 & 20 April & 10 May & 10 June & 13 April-13 July \\
\hline 1996 & 19 April & 15 May & 09 June & 19 April-03 July \\
\hline 1997 & 13 April & 28 April & 12 June & 07 April-15 June \\
\hline 1998 & 25 April & 12 May & 15 June & 02 April-07 August \\
\hline 1999 & 31 March & 04 May & 01 June & 27 March-11 June \\
\hline 2000 & 20 April & 18 May & 31 May & 12 April-20 July \\
\hline 2001 & 29 April & 14 May & 01 June & 26 April-07 July \\
\hline 2002 & 15 April & 03 May & 24 May & 11 April-09 June \\
\hline 2003 & 19 April & 16 May & 03 June & 19 April-12 June \\
\hline 2004 & 16 April & 10 May & 02 June & 08 April-19 June \\
\hline 2005 & 28 April & 12 May & 30 May & 22 April-19 June \\
\hline 2006 & 28 April & 11 May & 16 June & 27 April-18 June \\
\hline $2007^{\mathrm{a}}$ & --- & --- & --- & --- \\
\hline $2008^{\mathrm{a}}$ & --- & --- & --- & --- \\
\hline \multicolumn{5}{|l|}{ Big Creek (upper) } \\
\hline 1990 & 27 April & 30 May & 22 June & 17 April-18 July \\
\hline 1991 & 18 May & 10 June & 26 June & 26 April-01 July \\
\hline
\end{tabular}


Appendix Table 4a. Continued.

\begin{tabular}{|c|c|c|c|c|}
\hline \multirow[b]{2}{*}{ Year } & \multicolumn{4}{|c|}{ Percentile passage dates at Lower Granite Dam } \\
\hline & 10 th & 50 th & 90th & Range \\
\hline \multicolumn{5}{|c|}{ Big Creek (upper) (continued) } \\
\hline 1992 & 22 April & 08 May & 03 June & 15 April-26 June \\
\hline 1993 & 08 May & 18 May & 26 May & 26 April-15 June \\
\hline 1994 & 03 May & 19 May & 19 July & 25 April-30 August \\
\hline 1995 & 05 May & 23 May & 09 June & 02 May-26 June \\
\hline $1996^{\mathrm{a}} 1997^{\mathrm{a}} 1998^{\mathrm{a}}$ & --- & --- & --- & --- \\
\hline 1999 & 28 April & 14 May & 03 June & 25 April-19 June \\
\hline 2000 & 30 April & 27 May & 14 June & 15 April-29 June \\
\hline $2001^{\mathrm{a}} 2002^{\mathrm{a}}$ & --- & --- & --- & -- \\
\hline 2003 & 06 May & 25 May & 01 June & 01 May-21 June \\
\hline 2004 & 18 April & 12 May & 05 June & 15 April-17 June \\
\hline 2005 & 27 April & 07 May & 23 May & 20 April-07 June \\
\hline 2006 & 26 April & 08 May & 25 May & 19 April-10 June \\
\hline 2007 & 19 April & 06 May & 20 May & 15 April-18 June \\
\hline 2008 & 06 May & 20 May & 23 May & 25 April-05 June \\
\hline \multicolumn{5}{|c|}{ Big (lower)/Rush Creeks } \\
\hline 1993 & 24 April & 29 April & 13 May & 21 April-16 May \\
\hline 1994 & 23 April & 29 April & 11 May & 21 April-15 June \\
\hline 1995 & 19 April & 01 May & 14 May & 11 April-05 June \\
\hline $1996^{\mathrm{a}}$ & --- & --- & --- & --- \\
\hline $1997^{\mathrm{a}}$ & --- & --- & --- & --- \\
\hline $1998^{\mathrm{a}}$ & --- & --- & --- & --- \\
\hline 1999 & 19 April & 28 April & 23 May & 04 April-30 May \\
\hline 2000 & 19 April & 30 April & 13 May & 16 April-26 May \\
\hline $2001^{\mathrm{a}}$ & --- & --- & --- & --- \\
\hline 2002 & 15 April & 25 April & 07 May & 12 April-22 May \\
\hline 2003 & 14 April & 26 April & 18 May & 12 April-25 May \\
\hline 2004 & 15 April & 23 April & 04 May & 06 April-15 May \\
\hline $2005^{\mathrm{d}}$ & 22 April & 02 May & 09 May & 06 April-15 May \\
\hline $2006^{\mathrm{d}}$ & 11 April & 22 April & 03 May & 10 April-22 May \\
\hline $2007^{\mathrm{d}}$ & 18 April & 27 April & 06 May & 06 April-12 May \\
\hline $2008^{d}$ & 29 April & 12 May & 20 May & 23 April-20 May \\
\hline \multicolumn{5}{|c|}{ West Fork Chamberlain Creek } \\
\hline $1992^{c}$ & 15 April & 26 April & 03 June & 12 April-24 June \\
\hline 1993 & 28 April & 15 May & 23 June & 23 April-22 July \\
\hline $1994^{\mathrm{c}}$ & 24 April & 01 May & 05 July & 24 April-04 September \\
\hline $1995^{\mathrm{c}}$ & 16 April & 09 May & 20 June & 12 April-22 September \\
\hline $1996^{\mathrm{a}}-1997^{\mathrm{a}}$ & --- & --- & --- & --- \\
\hline $1998^{\mathrm{a}}$ & --- & --- & --- & --- \\
\hline $1999^{\mathrm{a}} 2000^{\mathrm{a}} 2001^{\mathrm{a}}$ & --- & --- & --- & --- \\
\hline 2002 & 26 April & 04 May & 20 May & 18 April-29 May \\
\hline $2003^{c}$ & 23 April & 20 May & 26 May & 21 April-26 May \\
\hline $2004^{\mathrm{c}}$ & 11 April & 24 April & 10 May & 07 April-23 June \\
\hline $2005^{\mathrm{c}}$ & 26 April & 03 May & 13 May & 20 April-30 May \\
\hline 2006 & 15 April & 01 May & 08 May & 14 April-19 May \\
\hline $2007^{\mathrm{c}}$ & 17 April & 02 May & 11 May & 17 April-24 May \\
\hline $2008^{a}$ & --- & --- & --- & --- \\
\hline
\end{tabular}


Appendix Table 4a. Continued.

\begin{tabular}{|c|c|c|c|c|}
\hline \multirow[b]{2}{*}{ Year } & \multicolumn{4}{|c|}{ Percentile passage dates at Lower Granite Dam } \\
\hline & 10th & 50 th & 90th & Range \\
\hline \multicolumn{5}{|c|}{ Secesh River } \\
\hline 1989 & 20 April & 27 April & 09 June & 09 April-19 July \\
\hline 1990 & 14 April & 22 April & 07 June & 10 April-13 July \\
\hline 1991 & 20 April & 27 April & 14 June & 13 April-20 July \\
\hline 1992 & 13 April & 29 April & 04 June & 05 April-03 July \\
\hline 1993 & 26 April & 16 May & 16 June & 22 April-15 July \\
\hline 1994 & 22 April & 26 April & 11 July & 21 April-07 August \\
\hline 1995 & 14 April & 01 May & 24 May & 10 April-10 July \\
\hline 1996 & 14 April & 25 April & 29 May & 12 April-15 July \\
\hline 1997 & 10 April & 18 April & 04 May & 04 April-11 July \\
\hline 1998 & 08 April & 24 April & 28 May & 03 April-06 July \\
\hline 1999 & 03 April & 23 April & 25 May & 29 March-21 June \\
\hline 2000 & 13 April & 23 April & 04 June & 12 April-11 July \\
\hline 2001 & 16 April & 28 April & 13 May & 06 April-13 June \\
\hline 2002 & 13 April & 21 April & 17 May & 11 April-01 July \\
\hline 2003 & 18 April & 30 April & 01 June & 03 April-04 July \\
\hline 2004 & 04 April & 27 April & 28 May & 01 April-13 June \\
\hline 2005 & 23 April & 03 May & 26 May & 04 April-19 June \\
\hline 2006 & 13 April & 24 April & 23 May & 08 April-08 June \\
\hline 2007 & 09 April & 22 April & 16 May & 05 April-23 May \\
\hline $2008^{a}$ & --- & --- & --- & -- \\
\hline \multicolumn{5}{|c|}{ Lake Creek } \\
\hline 1989 & 23 April & 02 May & 16 June & 12 April-01 July \\
\hline $1990^{\mathrm{a}}$ & --- & --- & --- & -- \\
\hline $1991^{\mathrm{a}}$ & --- & --- & --- & --- \\
\hline $1992^{\mathrm{a}}$ & --- & --- & --- & --- \\
\hline 1993 & 23 April & 09 May & 22 June & 22 April-25 June \\
\hline 1994 & 21 April & 28 April & 19 May & 20 April-24 June \\
\hline 1995 & 17 April & 10 May & 10 June & 14 April-20 July \\
\hline 1996 & 15 April & 21 April & 19 May & 15 April-02 June \\
\hline 1997 & 11 April & 25 April & 02 July & 07 April-22 September \\
\hline 1998 & 04 April & 25 April & 26 May & 02 April-16 July \\
\hline 1999 & 20 April & 26 April & 27 May & 08 April-20 June \\
\hline 2000 & 13 April & 04 May & 04 June & 13 April-18 July \\
\hline $2001^{\mathrm{a}}$ & -- & --- & --- & --- \\
\hline 2002 & 16 April & 29 April & 03 June & 13 April-03 June \\
\hline 2003 & 06 April & 06 May & 04 June & 06 April-20 June \\
\hline 2004 & 14 April & 25 April & 28 May & 09 April-16 June \\
\hline 2005 & 20 April & 28 April & 29 May & 19 April-19 June \\
\hline 2006 & 17 April & 28 April & 19 May & 17 April-19 May \\
\hline 2007 & 08 April & 27 April & 03 May & 08 April-14 May \\
\hline 2008 & 30 April & 07 May & 23 May & 25 April-24 May \\
\hline
\end{tabular}

${ }^{a}$ No parr were tagged the summer prior to this migration year.

${ }^{\mathrm{b}}$ Insufficient numbers detected to estimate timing.

${ }^{\mathrm{c}}$ Includes fish from Chamberlain Creek.

${ }^{\mathrm{d}}$ No fish were tagged in Rush Creek for this migration year. 
Appendix Table 4b. Accumulated and 2008 passage dates at Lower Granite Dam for PIT-tagged wild spring/summer Chinook salmon smolts from streams in Oregon.

\begin{tabular}{|c|c|c|c|c|}
\hline \multirow[b]{2}{*}{ Year } & \multicolumn{4}{|c|}{ Percentile passage dates at Lower Granite Dam } \\
\hline & 10th & 50th & 90th & Range \\
\hline \multicolumn{5}{|c|}{ Catherine Creek } \\
\hline 1991 & 01 May & 14 May & 08 June & 17 April-23 June \\
\hline 1992 & 16 April & 01 May & 21 May & 09 April-29 June \\
\hline 1993 & 06 May & 18 May & 05 June & 29 April-26 June \\
\hline 1994 & 25 April & 11 May & 20 May & 13 April-26 July \\
\hline 1995 & 01 May & 19 May & 09 June & 26 April-02 July \\
\hline $1996^{\mathrm{a}}$ & 19 April & 13 May & 29 May & 14 April-14 June \\
\hline 1997 & 08 May & 14 May & 01 June & 24 April-10 June \\
\hline 1998 & 28 April & 21 May & 28 May & 24 April-04 June \\
\hline 1999 & 26 April & 25 May & 15 June & 26 April-26 June \\
\hline 2000 & 30 April & 08 May & 23 May & 12 April-06 June \\
\hline 2001 & 29 April & 17 May & 17 June & 28 April-03 July \\
\hline 2002 & 24 April & 10 May & 18 June & 15 April-01 July \\
\hline 2003 & 26 April & 10 May & 09 June & 14 April-09 June \\
\hline 2004 & 22 April & 15 May & 11 June & 15 April-25 June \\
\hline 2005 & 20 April & 12 May & 23 May & 14 April-02 June \\
\hline 2006 & 28 April & 16 May & 30 May & 26 April-06 June \\
\hline 2007 & 19 April & 29 April & 17 May & 19 April-19 May \\
\hline 2008 & 06 May & o7 June & 02 July & 30 April-02 July \\
\hline \multicolumn{5}{|c|}{ Grande Ronde River (upper) } \\
\hline 1989 & 12 May & 06 June & 19 June & 27 April-22 July \\
\hline $1990^{\mathrm{b}}$ & -- & --- & --- & --- \\
\hline $1991^{\mathrm{b}}$ & --- & --- & --- & --- \\
\hline $1992^{b}$ & --- & --- & --- & --- \\
\hline 1993 & 05 May & 16 May & 25 May & 23 April-20 June \\
\hline 1994 & 28 April & 23 May & 07 July & 23 April-29 August \\
\hline 1995 & 27 April & 29 May & 12 June & 12 April-01 July \\
\hline $1996^{c}$ & 26 April & 17 May & 29 May & 19 April-06 June \\
\hline $1997^{b}-2008^{b}$ & --- & --- & --- & --- \\
\hline \multicolumn{5}{|c|}{ Imnaha River (lower) } \\
\hline 1989 & 11 April & 30 April & 11 May & 04 April-05 June \\
\hline 1990 & 10 April & 18 April & 09 May & 05 April-27 May \\
\hline 1991 & 20 April & 01 May & 13 May & 14 April-15 May \\
\hline 1992 & 10 April & 21 April & 03 May & 06 April-21 May \\
\hline $1993^{b}-\mathbf{2 0 0 8}^{b}$ & --- & --- & --- & --- \\
\hline \multicolumn{5}{|c|}{ Imnaha River (upper) } \\
\hline 1993 & 24 April & 14 May & 28 May & 15 April-23 June \\
\hline 1994 & 24 April & 08 May & 09 June & 20 April-11 August \\
\hline 1995 & 13 April & 02 May & 03 June & 10 April-07 July \\
\hline 1996 & 16 April & 26 April & 18 May & 14 April-12 June \\
\hline 1997 & 11 April & 19 April & 11 May & 03 April-02 June \\
\hline 1998 & 11 April & 28 April & 13 May & 03 April-24 May \\
\hline
\end{tabular}


Appendix Table 4b. Continued.

\begin{tabular}{|c|c|c|c|c|}
\hline \multirow[b]{2}{*}{ Year } & \multicolumn{4}{|c|}{ Percentile passage dates at Lower Granite Dam } \\
\hline & 10th & 50 th & 90th & Range \\
\hline \multicolumn{5}{|c|}{ Imnaha River (upper) (continued) } \\
\hline 1999 & 22 April & 08 May & 26 May & 17 April-03 June \\
\hline 2000 & 14 April & 02 May & 24 May & 12 April-16 June \\
\hline 2001 & 21 April & 30 April & 16 May & 08 April-28 May \\
\hline 2002 & 16 April & 04 May & 17 May & 15 April-31 May \\
\hline 2003 & 22 April & 08 May & 26 May & 17 April-31 May \\
\hline 2004 & 19 April & 04 May & 22 May & 18 April-8 June \\
\hline 2005 & 19 April & 03 May & 27 May & 05 April-11 June \\
\hline 2006 & 12 April & 29 April & 15 May & 03 April-04 June \\
\hline 2007 & 13 April & 25 April & 13 May & 05 April-24 May \\
\hline 2008 & 17 April & 06 May & 22 May & 14 April-01 June \\
\hline \multicolumn{5}{|c|}{ Lostine River } \\
\hline $1990^{\mathrm{d}}$ & --- & --- & --- & --- \\
\hline 1991 & 29 April & 14 May & 26 May & 20 April-09 July \\
\hline 1992 & 16 April & 30 April & 11 May & 12 April-02 June \\
\hline 1993 & 23 April & 03 May & 17 May & 17 April-01 June \\
\hline 1994 & 22 April & 30 April & 16 May & 19 April-07 June \\
\hline 1995 & 12 April & 02 May & 17 May & 08 April-09 June \\
\hline 1996 & 23 April & 15 May & 07 June & 17 April-19 June \\
\hline 1997 & 17 April & 28 April & 16 May & 09 April-21 May \\
\hline $1998^{\mathrm{b}}$ & --- & --- & --- & -- \\
\hline 1999 & 30 March & 09 May & 27 May & 29 March-29 May \\
\hline 2000 & 13 April & 08 May & 25 May & 13 April-03 June \\
\hline 2001 & 25 April & 09 May & 22 May & 10 April-12 June \\
\hline 2002 & 11 April & 21 April & 13 May & 28 March-29 May \\
\hline 2003 & 13 April & 08 May & 26 May & 11 April-03 June \\
\hline 2004 & 15 April & 04 May & 05 June & 14 April-15 June \\
\hline 2005 & 16 April & 29 April & 26 May & 05 April-18 June \\
\hline 2006 & 14 April & 26 April & 16 May & 05 April-09 June \\
\hline 2007 & 14 April & 03 May & 15 May & 05 April-21 May \\
\hline 2008 & 22 April & 11 May & 29 Мау & 10 April-14 June \\
\hline \multicolumn{5}{|c|}{ Minam River } \\
\hline 1999 & 08 April & 28 April & 25 May & 31 March-02 June \\
\hline 2000 & 15 April & 03 May & 22 May & 10 April-29 May \\
\hline 2001 & 25 April & 07 May & 23 May & 08 April-12 June \\
\hline 2002 & 17 April & 03 May & 20 May & 16 April-31 May \\
\hline 2003 & 17 April & 13 May & 29 May & 13 April-01 June \\
\hline 2004 & 15 April & 28 April & 28 May & 08 April-31 May \\
\hline 2005 & 19 April & 08 May & 21 May & 08 April-08 June \\
\hline 2006 & 13 April & 08 May & 20 May & 11 April-06 June \\
\hline 2007 & 11 April & 27 April & 12 May & 04 April-22 May \\
\hline 2008 & 23 April & 08 May & 21 May & 17 April-11 June \\
\hline
\end{tabular}

a Includes fish tagged from summer 1995 through spring 1996.

${ }^{\mathrm{b}}$ No parr were tagged the summer prior to this migration year.

${ }^{c}$ All fish tagged at traps in fall or spring for this migration year.

${ }^{\mathrm{d}}$ Insufficient numbers detected to estimate timing. 
Appendix Table 5. Detections during 2008 of PIT-tagged smolts by date at four Snake River dams and three Columbia River dams for 514 wild Chinook salmon from Bear Valley Creek released 26-28 July 2007. Release sites were 629-634 km above Lower Granite Dam.

\begin{tabular}{|c|c|c|c|c|c|c|c|c|}
\hline \multirow[b]{2}{*}{$\begin{array}{l}\text { Detection } \\
\text { date }\end{array}$} & \multicolumn{8}{|c|}{$\begin{array}{c}\text { Bear Valley Creek } \\
\text { First detections }\end{array}$} \\
\hline & $\begin{array}{c}\text { First } \\
\text { detection }\end{array}$ & $\overline{\text { Expanded }}$ & $\begin{array}{l}\text { Little } \\
\text { Goose }\end{array}$ & $\begin{array}{c}\text { Lower } \\
\text { Monumental }\end{array}$ & $\begin{array}{c}\text { Ice } \\
\text { Harbor }\end{array}$ & McNary & $\begin{array}{l}\text { John } \\
\text { Day }\end{array}$ & Bonneville \\
\hline $24 \mathrm{Apr}$ & 1 & 3 & & & & & & \\
\hline $27 \mathrm{Apr}$ & 1 & 3 & & & & & & \\
\hline $30 \mathrm{Apr}$ & 2 & 6 & 1 & & & & & \\
\hline 01 May & & & 1 & & & & & \\
\hline 02 May & 1 & 2 & & & & & & \\
\hline 05 May & 5 & 10 & & & & & & \\
\hline 06 May & 1 & 2 & & 1 & & & & \\
\hline 07 May & 4 & 8 & & 1 & & & & \\
\hline 08 May & 1 & 2 & & & & & & \\
\hline 09 May & 2 & 4 & 2 & 1 & & & & \\
\hline 10 May & & & & 1 & 1 & & & \\
\hline 11 May & & & 3 & & & & & \\
\hline 12 May & 2 & 5 & 2 & 1 & & & & \\
\hline 14 May & 2 & 5 & & 1 & & & & \\
\hline 15 May & 2 & 5 & & & & & & \\
\hline 16 May & 1 & 3 & 1 & & & & & \\
\hline 17 May & 1 & 3 & & 1 & & & & \\
\hline 18 May & 3 & 11 & 2 & 1 & & & & \\
\hline 19 May & 1 & 4 & 2 & & & & 1 & \\
\hline 20 May & & & 3 & & & & & \\
\hline 21 May & & & 1 & & 1 & & & \\
\hline 22 May & 1 & 5 & & & & & & \\
\hline 23 May & & & 2 & & & 1 & & \\
\hline 26 May & & & 1 & & & & & \\
\hline 27 May & 1 & 4 & 1 & 1 & & & & \\
\hline 29 May & & & & 1 & & & 1 & \\
\hline 01 Jun & & & 2 & & & & & \\
\hline 04 Jun & 1 & 3 & 1 & 1 & & & 1 & \\
\hline 06 Jun & & & & & & & 1 & \\
\hline 10 Jun & 1 & 3 & & & & & & \\
\hline 11 Jun & & & 1 & & & & & \\
\hline 20 Jun & & & & & & & & 1 \\
\hline 27 Jun & & & & & & 1 & & \\
\hline $07 \mathrm{Jul}$ & & & & & & & & 1 \\
\hline Totals & 34 & 91 & 26 & 11 & 2 & 2 & 4 & 2 \\
\hline
\end{tabular}


Appendix Table 6. Detections during 2008 of PIT-tagged smolts by date at four Snake River dams and three Columbia River dams for 500 wild Chinook salmon from Elk Creek released 28-29 July 2007. Release sites were 634-637 km above Lower Granite Dam.

\begin{tabular}{|c|c|c|c|c|c|c|c|c|}
\hline \multirow{4}{*}{$\begin{array}{l}\text { Detection } \\
\text { date }\end{array}$} & \multicolumn{8}{|c|}{ Elk Creek } \\
\hline & \multicolumn{2}{|c|}{ Lower Granite } & \multicolumn{6}{|c|}{ First detections } \\
\hline & First & & Little & Lower & Ice & & John & \\
\hline & detection & Expanded & Goose & Monumental & Harbor & McNary & Day & Bonneville \\
\hline $25 \mathrm{Apr}$ & 1 & 3 & & & & & & \\
\hline 29 Apr & 1 & 3 & & & & & & \\
\hline 01 May & 2 & 5 & & 1 & & & & \\
\hline 02 May & 2 & 4 & & & & & & \\
\hline 03 May & 1 & 2 & & & & & & \\
\hline 04 May & 2 & 4 & & & & & & \\
\hline 05 May & 2 & 4 & & & & & & \\
\hline 06 May & 7 & 15 & & & & & & \\
\hline 07 May & 2 & 4 & 1 & & & & & \\
\hline 08 May & 2 & 4 & 1 & & & & & \\
\hline 09 May & 2 & 4 & 1 & 1 & & & & \\
\hline 10 May & 5 & 10 & 1 & & 1 & & & \\
\hline 11 May & 2 & 4 & 3 & & & & & \\
\hline 12 May & 6 & 14 & & & & & & \\
\hline 13 May & 5 & 11 & 1 & & & & & \\
\hline 15 May & 1 & 2 & 1 & & & & & \\
\hline 16 May & 1 & 3 & 2 & & & & & \\
\hline 17 May & 1 & 3 & 1 & 1 & 1 & & & \\
\hline 18 May & 1 & 4 & 1 & 1 & 1 & & & \\
\hline 19 May & & & 1 & 1 & & & & \\
\hline 21 May & & & 2 & & 1 & & & \\
\hline 22 May & 1 & 5 & 1 & 1 & & & & \\
\hline 23 May & 2 & 12 & 2 & & 1 & & & \\
\hline 24 May & & & & 1 & & & & \\
\hline 25 May & & & & & & 1 & & \\
\hline 26 May & & & 1 & & 1 & & & \\
\hline 27 May & & & & 1 & & & & \\
\hline 28 May & & & 2 & & & 1 & & \\
\hline 30 May & & & & 1 & & & & \\
\hline 31 May & & & 2 & & & & & \\
\hline 01 Jun & & & & & & & 1 & \\
\hline 02 Jun & & & & & & 1 & & \\
\hline 04 Jun & 1 & 3 & 1 & & 1 & 1 & & \\
\hline 05 Jun & & & & 1 & & & & \\
\hline 06 Jun & & & & & & 1 & & \\
\hline 11 Jun & & & & & & 1 & & \\
\hline 15 Jun & & & & & & & & 1 \\
\hline 16 Jun & 1 & 3 & & & & & & \\
\hline 23 Jun & & & 1 & & & 1 & & \\
\hline Totals & 51 & 125 & 26 & 10 & 7 & 7 & 1 & 1 \\
\hline
\end{tabular}


Appendix Table 7. Detections during 2008 of PIT-tagged smolts by date at four Snake River dams and three Columbia River dams for 499 wild Chinook salmon from Marsh Creek released 30-31 July 2007. Release sites were 632-634 km above Lower Granite Dam.

\begin{tabular}{|c|c|c|c|c|c|c|c|c|}
\hline \multirow[b]{3}{*}{$\begin{array}{l}\text { Detection } \\
\text { date }\end{array}$} & \multicolumn{8}{|c|}{ Marsh Creek } \\
\hline & \multicolumn{2}{|c|}{ Lower Granite } & \multicolumn{6}{|c|}{ First detections } \\
\hline & $\begin{array}{c}\text { First } \\
\text { detection }\end{array}$ & Expanded & $\begin{array}{l}\text { Little } \\
\text { Goose }\end{array}$ & $\begin{array}{c}\text { Lower } \\
\text { Monumental }\end{array}$ & $\begin{array}{c}\text { Ice } \\
\text { Harbor }\end{array}$ & McNary & $\begin{array}{l}\text { John } \\
\text { Day }\end{array}$ & Bonneville \\
\hline $24 \mathrm{Apr}$ & 1 & 3 & & & & & & \\
\hline $27 \mathrm{Apr}$ & 1 & 3 & & & & & & \\
\hline $28 \mathrm{Apr}$ & 1 & 3 & & & & & & \\
\hline 29 Apr & 1 & 3 & 1 & & & & & \\
\hline $30 \mathrm{Apr}$ & 3 & 9 & & & & & & \\
\hline 01 May & 2 & 5 & & & & & & \\
\hline 03 May & 2 & 4 & & & & & & \\
\hline 04 May & 1 & 2 & & & & & & \\
\hline 05 May & 1 & 2 & & & & & & \\
\hline 06 May & 2 & 4 & & & & & & \\
\hline 07 May & 6 & 12 & & & & & & \\
\hline 08 May & 1 & 2 & 1 & 2 & & & & \\
\hline 09 May & 2 & 4 & & 1 & & & & \\
\hline 10 May & 3 & 6 & 1 & & & & & \\
\hline 11 May & 2 & 4 & 1 & & & & & \\
\hline 12 May & 3 & 7 & 1 & 1 & & & & \\
\hline 13 May & 2 & 4 & & & & & & \\
\hline 14 May & 1 & 2 & & & & 1 & & \\
\hline 15 May & 1 & 2 & 2 & 1 & & & & \\
\hline 17 May & 2 & 6 & 1 & & & 1 & & \\
\hline 18 May & 1 & 4 & 1 & & 2 & & 1 & \\
\hline 19 May & & & 1 & & & & & \\
\hline 20 May & 1 & 6 & 2 & 1 & & & 1 & \\
\hline 21 May & & & 2 & 2 & & & & \\
\hline 22 May & & & & & & 1 & 1 & \\
\hline 23 May & & & 3 & 2 & 1 & & & 2 \\
\hline 25 May & & & & & 1 & 1 & & \\
\hline 26 May & & & & 1 & & & & \\
\hline 27 May & & & & 1 & & & & \\
\hline 30 May & & & & 1 & & & & \\
\hline 05 Jun & & & & 1 & & & & \\
\hline Totals & 40 & 96 & 17 & 14 & 4 & 4 & 3 & 2 \\
\hline
\end{tabular}


Appendix Table 8. Detections during 2008 of PIT-tagged smolts by date at four Snake River dams and three Columbia River dams for 499 wild Chinook salmon from Cape Horn Creek released 31 July-1 August 2007. Release sites were 630-631 km above Lower Granite Dam.

\begin{tabular}{|c|c|c|c|c|c|c|c|c|}
\hline \multirow[b]{2}{*}{$\begin{array}{l}\text { Detection } \\
\text { date }\end{array}$} & \multicolumn{8}{|c|}{ Cape Horn Creek } \\
\hline & $\begin{array}{c}\text { First } \\
\text { detection }\end{array}$ & Expanded & $\begin{array}{l}\text { Little } \\
\text { Goose }\end{array}$ & $\begin{array}{c}\text { Lower } \\
\text { Monumental }\end{array}$ & $\begin{array}{c}\text { Ice } \\
\text { Harbor }\end{array}$ & McNary & $\begin{array}{l}\text { John } \\
\text { Day }\end{array}$ & Bonneville \\
\hline $25 \mathrm{Apr}$ & 1 & 3 & & & & & & \\
\hline 01 May & 2 & 5 & & & & & & \\
\hline 03 May & 3 & 6 & 2 & & & & & \\
\hline 04 May & 1 & 2 & & & & & & \\
\hline 05 May & 1 & 2 & & & & & & \\
\hline 06 May & 3 & 6 & & & & & & \\
\hline 07 May & 2 & 4 & & 1 & & & & \\
\hline 08 May & 2 & 4 & 1 & & & & & \\
\hline 09 May & 2 & 4 & 2 & & & & & \\
\hline 10 May & 1 & 2 & 3 & & & & & \\
\hline 11 May & 3 & 6 & 2 & & & & & \\
\hline 12 May & 2 & 5 & & & & & & \\
\hline 13 May & 3 & 6 & 2 & 1 & & & & \\
\hline 14 May & 4 & 9 & & & & & & \\
\hline 16 May & 1 & 3 & 1 & 1 & & & & \\
\hline 17 May & & & 2 & 1 & & & & \\
\hline 18 May & 3 & 11 & 1 & 1 & & & & \\
\hline 19 May & 4 & 17 & & 1 & & & & \\
\hline 20 May & 1 & 6 & 1 & & & & & \\
\hline 21 May & 1 & 5 & 2 & 1 & & & 1 & \\
\hline 22 May & 2 & 11 & 4 & 2 & 2 & & & \\
\hline 23 May & 1 & 6 & 4 & 2 & & & & \\
\hline 24 May & 1 & 5 & 3 & 1 & & & & \\
\hline 25 May & & & 1 & & & & & \\
\hline 26 May & 1 & 4 & & 1 & & & & \\
\hline 27 May & & & & 2 & & & & \\
\hline 29 May & & & & 1 & & & 1 & \\
\hline 30 May & & & & & & & & 1 \\
\hline 01 Jun & & & 1 & & & & & \\
\hline 03 Jun & 1 & 4 & & & & & & \\
\hline 06 Jun & & & & 1 & & & & \\
\hline 07 Jun & & & 1 & & & & & \\
\hline Totals & 46 & 134 & 33 & 17 & 2 & 0 & 2 & 1 \\
\hline
\end{tabular}


Appendix Table 9. Detections during 2008 of PIT-tagged smolts by date at four Snake River dams and three Columbia River dams for 375 wild Chinook salmon from Sulphur Creek released 1 August 2007. Fish were released 604-608 km above Lower Granite Dam.

\begin{tabular}{|c|c|c|c|c|c|c|c|c|}
\hline \multirow{4}{*}{$\begin{array}{l}\text { Detection } \\
\text { date }\end{array}$} & \multicolumn{8}{|c|}{ Sulphur Creek } \\
\hline & \multicolumn{2}{|c|}{ Lower Granite } & \multicolumn{6}{|c|}{ First detections } \\
\hline & First & & Little & Lower & Ice & & John & \\
\hline & detection & Expanded & Goose & Monumental & Harbor & McNary & Day & Bonneville \\
\hline $27 \mathrm{Apr}$ & 1 & 3 & & & & & & \\
\hline $30 \mathrm{Apr}$ & 1 & 3 & & 1 & & & & \\
\hline 01 May & 1 & 2 & & & & & & \\
\hline 03 May & 1 & 2 & 1 & & & & & \\
\hline 04 May & 1 & 2 & 1 & & & & & \\
\hline 05 May & 2 & 4 & & & & & & \\
\hline 06 May & 4 & 8 & & & & & & \\
\hline 07 May & 4 & 8 & & & & & & \\
\hline 08 May & & & 1 & & & & & \\
\hline 09 May & 3 & 6 & 1 & 1 & & & & \\
\hline 10 May & 1 & 2 & & & & & & \\
\hline 11 May & 1 & 2 & & & & & & \\
\hline 12 May & 3 & 7 & 1 & & & & & \\
\hline 13 May & 1 & 2 & & & & & & \\
\hline 14 May & 1 & 2 & 1 & & & & & \\
\hline 15 May & & & & & & 1 & & \\
\hline 16 May & 1 & 3 & 1 & & & & & \\
\hline 17 May & 1 & 3 & & 1 & & & & \\
\hline 18 May & & & 1 & & & 2 & & \\
\hline 19 May & 2 & 8 & 1 & & & & & \\
\hline 20 May & & & & 1 & & & & \\
\hline 21 May & & & 2 & 2 & & & & \\
\hline 22 May & 1 & 5 & 1 & & & & & \\
\hline 24 May & & & 1 & 1 & & & & \\
\hline 25 May & 1 & 4 & & & & & & \\
\hline 26 May & & & 2 & 1 & 1 & & & \\
\hline 27 May & & & & 1 & & & & \\
\hline 29 May & & & & & & & 1 & \\
\hline 30 May & & & & & & & 1 & \\
\hline 31 May & & & & & & & 1 & \\
\hline 02 Jun & 2 & 6 & & & & & & \\
\hline 03 Jun & & & 1 & & 1 & & & \\
\hline 04 Jun & 1 & 3 & & & & & & \\
\hline 06 Jun & & & 1 & 1 & & & & \\
\hline 08 Jun & & & 1 & 1 & & & & \\
\hline 11 Jun & & & 1 & & & & & \\
\hline 18 Jun & & & & 1 & & & & \\
\hline Totals & 34 & 87 & 19 & 12 & 2 & 3 & 3 & 0 \\
\hline
\end{tabular}


Appendix Table 10. Detections during 2008 of PIT-tagged smolts by date at four Snake River dams and three Columbia River dams for 2,524 wild Chinook salmon from Valley Creek released 1-4 August 2007. Release sites were 743-751 km above Lower Granite Dam.

\begin{tabular}{|c|c|c|c|c|c|c|c|c|}
\hline \multirow[b]{3}{*}{$\begin{array}{l}\text { Detection } \\
\text { date }\end{array}$} & \multicolumn{8}{|c|}{ Valley Creek } \\
\hline & \multicolumn{2}{|c|}{ Lower Granite } & \multirow[b]{2}{*}{$\begin{array}{c}\text { Little } \\
\text { Goose }\end{array}$} & \multirow[b]{2}{*}{$\begin{array}{c}\text { Lower } \\
\text { Monumental }\end{array}$} & \multicolumn{2}{|c|}{ First detections } & \multirow[b]{2}{*}{ John } & \multirow[b]{2}{*}{ Bonneville } \\
\hline & $\begin{array}{c}\text { First } \\
\text { detection }\end{array}$ & Expanded & & & $\begin{array}{c}\text { Ice } \\
\text { Harbor }\end{array}$ & McNary & & \\
\hline $21 \mathrm{Apr}$ & 1 & 3 & & & & & & \\
\hline $23 \mathrm{Apr}$ & 4 & 12 & & & & & & \\
\hline 24 Apr & 1 & 3 & & & & & & \\
\hline $25 \mathrm{Apr}$ & 2 & 5 & & & & & & \\
\hline $26 \mathrm{Apr}$ & 2 & 6 & & & & & & \\
\hline $28 \mathrm{Apr}$ & 1 & 3 & & & & & & \\
\hline 29 Apr & 2 & 6 & & & & & & \\
\hline $30 \mathrm{Apr}$ & 2 & 6 & & & & & & \\
\hline 01 May & 1 & 2 & & & & & & \\
\hline 02 May & 3 & 7 & & & & & & \\
\hline 03 May & 2 & 4 & 3 & & & & & \\
\hline 04 May & 4 & 9 & & 1 & & & & \\
\hline 05 May & 1 & 2 & & & & & & \\
\hline 06 May & 8 & 17 & 2 & & 1 & & & \\
\hline 07 May & 13 & 25 & 1 & 2 & 1 & & & \\
\hline 08 May & 4 & 8 & 3 & 1 & & 1 & & \\
\hline 09 May & 4 & 8 & & 1 & & & & \\
\hline 10 May & 6 & 12 & 5 & & & 1 & & \\
\hline 11 May & 10 & 20 & & & & & & \\
\hline 12 May & 3 & 7 & 4 & & & 1 & & \\
\hline 13 May & 11 & 24 & 2 & & & & & \\
\hline 14 May & 6 & 14 & 4 & 1 & & & & \\
\hline 15 May & 1 & 2 & 1 & & & & & \\
\hline 16 May & 5 & 14 & 1 & & & & & \\
\hline 17 May & 1 & 3 & 1 & & & & & \\
\hline 18 May & 4 & 14 & 2 & & & & & \\
\hline 19 May & 1 & 4 & 2 & 2 & & & & 1 \\
\hline 20 May & 4 & 22 & 2 & 3 & & & 1 & \\
\hline 21 May & 1 & 5 & 4 & 2 & & & 1 & \\
\hline 22 May & 1 & 5 & 2 & 1 & & & & \\
\hline 23 May & & & 4 & 2 & 3 & & 1 & \\
\hline 24 May & & & & 3 & & 1 & & \\
\hline 25 May & 1 & 4 & 1 & & & & 1 & \\
\hline 26 May & 1 & 4 & 1 & & & & & \\
\hline 27 May & & & & & 1 & & 1 & \\
\hline 28 May & 1 & 4 & 1 & 1 & 1 & & & \\
\hline 29 May & 3 & 13 & 1 & & & 1 & 1 & \\
\hline
\end{tabular}


Appendix Table 10. Continued.

\begin{tabular}{|c|c|c|c|c|c|c|c|c|}
\hline \multirow[b]{2}{*}{$\begin{array}{l}\text { Detection } \\
\text { date }\end{array}$} & \multicolumn{8}{|c|}{ Valley Creek (continued) } \\
\hline & $\begin{array}{c}\text { First } \\
\text { detection }\end{array}$ & Expanded & $\begin{array}{l}\text { Little } \\
\text { Goose }\end{array}$ & $\begin{array}{c}\text { Lower } \\
\text { Monumental }\end{array}$ & $\begin{array}{c}\text { Ice } \\
\text { Harbor }\end{array}$ & McNary & $\begin{array}{l}\text { John } \\
\text { Day }\end{array}$ & Bonneville \\
\hline 30 May & & & 1 & 1 & & & 1 & \\
\hline 31 May & & & 2 & & & & & \\
\hline 01 Jun & & & 2 & 1 & & & & \\
\hline 02 Jun & 1 & 3 & & & & & & \\
\hline 03 Jun & 1 & 4 & & 1 & & & & \\
\hline 04 Jun & & & 2 & 1 & & & & \\
\hline 06 Jun & 1 & 3 & 1 & & & & & \\
\hline 09 Jun & & & & & & 1 & & \\
\hline 11 Jun & & & 2 & & & & & \\
\hline 13 Jun & & & 1 & & & & & \\
\hline 14 Jun & & & & & 1 & & & \\
\hline 16 Jun & & & & & 1 & & & \\
\hline $02 \mathrm{Jul}$ & & & & & & & 1 & \\
\hline Totals & 118 & 305 & 59 & 25 & 10 & 6 & 8 & 1 \\
\hline
\end{tabular}


Appendix Table 11. Detections during 2008 of PIT-tagged smolts by date at four Snake River dams and three Columbia River dams for 320 wild Chinook salmon from Herd Creek released 6 August 2007. Fish were released 699-702 km above Lower Granite Dam.

\begin{tabular}{|c|c|c|c|c|c|c|c|c|}
\hline \multirow[b]{3}{*}{$\begin{array}{l}\text { Detection } \\
\text { date }\end{array}$} & \multicolumn{8}{|c|}{ Herd Creek } \\
\hline & \multicolumn{2}{|c|}{ Lower Granite } & \multirow[b]{2}{*}{$\begin{array}{c}\text { Little } \\
\text { Goose }\end{array}$} & \multirow[b]{2}{*}{$\begin{array}{c}\text { Lower } \\
\text { Monumental } \\
\end{array}$} & \multicolumn{2}{|c|}{ First detections } & \multirow[b]{2}{*}{ John } & \multirow[b]{2}{*}{ Bonneville } \\
\hline & $\begin{array}{c}\text { First } \\
\text { detection }\end{array}$ & Expanded & & & $\begin{array}{c}\text { Ice } \\
\text { Harbor }\end{array}$ & McNary & & \\
\hline $24 \mathrm{Apr}$ & 1 & 3 & & & & & & \\
\hline $25 \mathrm{Apr}$ & 1 & 3 & & & & & & \\
\hline $26 \mathrm{Apr}$ & 1 & 3 & & & & & & \\
\hline 29 Apr & 1 & 3 & & & & & & \\
\hline $30 \mathrm{Apr}$ & 2 & 6 & & & & & & \\
\hline 01 May & 2 & 5 & & & & & & \\
\hline 02 May & 1 & 2 & & & & & & \\
\hline 03 May & 1 & 2 & & & & & & \\
\hline 04 May & 1 & 2 & & & & & & \\
\hline 05 May & 1 & 2 & & & & & & \\
\hline 06 May & 1 & 2 & & 1 & & & & \\
\hline 07 May & 4 & 8 & & & & & & \\
\hline 08 May & 3 & 6 & 2 & 2 & & & & \\
\hline 09 May & 2 & 4 & 1 & & & & & \\
\hline 10 May & 4 & 8 & 1 & & & & & \\
\hline 11 May & 8 & 16 & 2 & & & 1 & & \\
\hline 12 May & 1 & 2 & 2 & 1 & & & & \\
\hline 13 May & 3 & 6 & 2 & 1 & & 1 & & \\
\hline 15 May & & & 1 & & & & & \\
\hline 17 May & 1 & 3 & 1 & & 1 & & & \\
\hline 18 May & 2 & 7 & 2 & & & & & \\
\hline 19 May & 2 & 8 & 2 & 1 & & & & \\
\hline 20 May & & & 3 & 1 & 1 & & & \\
\hline 21 May & & & 1 & & & & & \\
\hline 23 May & 1 & 6 & & & 2 & & & \\
\hline 24 May & & & & 1 & & & & \\
\hline 28 May & & & 3 & & & & & \\
\hline 03 Jun & & & 1 & & & 1 & & \\
\hline Totals & 44 & 107 & 24 & 8 & 4 & 3 & 0 & 0 \\
\hline
\end{tabular}


Appendix Table 12. Detections during 2008 of PIT-tagged smolts by date at four Snake River dams and three Columbia River dams for 507 wild Chinook salmon from Camas Creek released 8-9 August 2007. Release sites were 524-526 km above Lower Granite Dam.

\begin{tabular}{|c|c|c|c|c|c|c|c|c|}
\hline \multirow[b]{3}{*}{$\begin{array}{l}\text { Detection } \\
\text { date }\end{array}$} & \multicolumn{8}{|c|}{ Camas Creek } \\
\hline & \multicolumn{2}{|c|}{ Lower Granite } & \multicolumn{6}{|c|}{ First detections } \\
\hline & $\begin{array}{c}\text { First } \\
\text { detection }\end{array}$ & Expanded & $\begin{array}{c}\text { Little } \\
\text { Goose }\end{array}$ & $\begin{array}{c}\text { Lower } \\
\text { Monumental }\end{array}$ & $\begin{array}{c}\text { Ice } \\
\text { Harbor }\end{array}$ & McNary & $\begin{array}{l}\text { John } \\
\text { Day }\end{array}$ & Bonneville \\
\hline $27 \mathrm{Apr}$ & 1 & 3 & & & & & & \\
\hline $29 \mathrm{Apr}$ & 1 & 3 & & & & & & \\
\hline 01 May & 1 & 2 & & & & & & \\
\hline 02 May & 1 & 2 & & & & & & \\
\hline 04 May & 1 & 2 & & & & & & \\
\hline 05 May & 1 & 2 & & & & & & \\
\hline 06 May & 3 & 6 & & & & & & \\
\hline 07 May & 2 & 4 & & & & & & \\
\hline 08 May & 6 & 12 & & & & & & \\
\hline 09 May & 3 & 6 & 1 & & & & & \\
\hline 10 May & 5 & 10 & & & & 1 & & \\
\hline 11 May & 1 & 2 & 3 & 1 & & & & \\
\hline 12 May & 2 & 5 & 4 & 1 & & 1 & & \\
\hline 13 May & 1 & 2 & 1 & 1 & & & & \\
\hline 14 May & 2 & 5 & 1 & 1 & & & & \\
\hline 15 May & 2 & 5 & & & & 1 & & \\
\hline 16 May & & & 1 & & & & & \\
\hline 17 May & 2 & 6 & 1 & & & 1 & & \\
\hline 18 May & 3 & 11 & 1 & & 1 & & & \\
\hline 19 May & 2 & 8 & 1 & & & & & \\
\hline 20 May & 2 & 11 & 3 & 1 & 1 & & & \\
\hline 21 May & 2 & 10 & 1 & 1 & & & & \\
\hline 22 May & & & 2 & 2 & 1 & & 1 & 1 \\
\hline 24 May & & & 1 & & & & 1 & \\
\hline 25 May & 1 & 4 & & & 1 & & 1 & 1 \\
\hline 27 May & & & 2 & & & & & \\
\hline 28 May & & & 2 & & & 1 & & \\
\hline 30 May & & & 1 & & & & & \\
\hline 31 May & 1 & 4 & 1 & & & & & \\
\hline Totals & 46 & 124 & 27 & 8 & 4 & 5 & 3 & 2 \\
\hline
\end{tabular}


Appendix Table 13. Detections during 2008 of PIT-tagged smolts by date at four Snake River dams and three Columbia River dams for 276 wild Chinook salmon from Loon Creek released 8-9 August 2007. Release sites were 550-553 km above Lower Granite Dam.

\begin{tabular}{|c|c|c|c|c|c|c|c|c|}
\hline \multirow[b]{3}{*}{$\begin{array}{l}\text { Detection } \\
\text { date }\end{array}$} & \multicolumn{8}{|c|}{ Loon Creek } \\
\hline & \multicolumn{2}{|c|}{ Lower Granite } & \multicolumn{6}{|c|}{ First detections } \\
\hline & $\begin{array}{c}\text { First } \\
\text { detection }\end{array}$ & Expanded & $\begin{array}{l}\text { Little } \\
\text { Goose }\end{array}$ & $\begin{array}{c}\text { Lower } \\
\text { Monumental }\end{array}$ & $\begin{array}{c}\text { Ice } \\
\text { Harbor }\end{array}$ & McNary & $\begin{array}{l}\text { John } \\
\text { Day }\end{array}$ & Bonneville \\
\hline $28 \mathrm{Apr}$ & 1 & 3 & 1 & & & & & \\
\hline $30 \mathrm{Apr}$ & 1 & 3 & & & & & & \\
\hline 06 May & 2 & 4 & & & & & & \\
\hline 07 May & 5 & 10 & & & & & & \\
\hline 08 May & 3 & 6 & 1 & & & & & \\
\hline 09 May & & & 1 & & & & & \\
\hline 10 May & & & 1 & & & & & \\
\hline 11 May & 2 & 4 & & & & & & \\
\hline 12 May & 1 & 2 & & & & & & \\
\hline 13 May & 3 & 6 & 1 & 1 & & & & 1 \\
\hline 14 May & 1 & 2 & 1 & & & & & \\
\hline 15 May & 1 & 2 & & & & & & \\
\hline 16 May & 3 & 8 & & & & & 1 & \\
\hline 17 May & 3 & 9 & 1 & & & & & \\
\hline 18 May & 2 & 7 & 2 & & & & & \\
\hline 19 May & 1 & 4 & 1 & & & 1 & & \\
\hline 20 May & 1 & 6 & 1 & 2 & & & & \\
\hline 21 May & 1 & 5 & 1 & 1 & & & & \\
\hline 22 May & & & 1 & 1 & & & & \\
\hline 23 May & 2 & 12 & & & 1 & & & \\
\hline 24 May & & & & & 1 & & & 1 \\
\hline 25 May & & & & & & & 1 & \\
\hline 26 May & 1 & 4 & & & & & & \\
\hline 27 May & 1 & 4 & & & & & 1 & \\
\hline 28 May & & & & & & & 1 & \\
\hline 29 May & 1 & 4 & & 1 & & & 2 & \\
\hline 30 May & & & & & 1 & & & \\
\hline 31 May & & & 1 & & & & & \\
\hline 04 Jun & & & 1 & & & & & \\
\hline 05 Jun & & & & 1 & & & & \\
\hline 10 Jun & & & & & & & 1 & \\
\hline Totals & 36 & 106 & 15 & 7 & 3 & 1 & 7 & 2 \\
\hline
\end{tabular}


Appendix Table 14. Detections during 2008 of PIT-tagged smolts by date at three Snake River dams and three Columbia River dams for 501 wild Chinook salmon from Lake Creek released 12 August 2007. Release sites were 451-452 km above Lower Granite Dam.

\begin{tabular}{|c|c|c|c|c|c|c|c|c|}
\hline \multirow[b]{3}{*}{$\begin{array}{l}\text { Detection } \\
\text { date }\end{array}$} & \multicolumn{8}{|c|}{ Lake Creek } \\
\hline & \multicolumn{2}{|c|}{ Lower Granite } & \multicolumn{6}{|c|}{ First detections } \\
\hline & $\begin{array}{c}\text { First } \\
\text { detection }\end{array}$ & Expanded & $\begin{array}{l}\text { Little } \\
\text { Goose }\end{array}$ & $\begin{array}{c}\text { Lower } \\
\text { Monumental }\end{array}$ & $\begin{array}{c}\text { Ice } \\
\text { Harbor }\end{array}$ & McNary & $\begin{array}{l}\text { John } \\
\text { Day }\end{array}$ & Bonneville \\
\hline $25 \mathrm{Apr}$ & 1 & 3 & & & & & & \\
\hline $29 \mathrm{Apr}$ & 2 & 6 & & & & & & \\
\hline $30 \mathrm{Apr}$ & 1 & 3 & & & & & & \\
\hline 02 May & 5 & 11 & & & & & & \\
\hline 03 May & 1 & 2 & 1 & & & & & \\
\hline 04 May & 2 & 4 & & & & & & \\
\hline 05 May & 4 & 8 & & & & & & \\
\hline 06 May & 5 & 11 & & & & & & \\
\hline 07 May & 5 & 10 & 2 & & & & & \\
\hline 08 May & 3 & 6 & 3 & & 1 & & & \\
\hline 09 May & 2 & 4 & & & & & & \\
\hline 10 May & 2 & 4 & & & & & & \\
\hline 11 May & 1 & 2 & 1 & & 1 & & & \\
\hline 12 May & 2 & 5 & & & & 1 & & \\
\hline 13 May & & & & 1 & & & & \\
\hline 14 May & & & & & & 2 & & \\
\hline 16 May & 1 & 3 & & & & & & \\
\hline 17 May & & & & & & 2 & & \\
\hline 18 May & 2 & 7 & & & & & & \\
\hline 19 May & & & 2 & & & & & \\
\hline 20 May & 1 & 6 & & & & & 1 & \\
\hline 23 May & 2 & 12 & 1 & & & & & \\
\hline 24 May & 1 & 5 & & & & & & \\
\hline 25 May & & & 1 & & & & & \\
\hline 27 May & & & 1 & & & & & \\
\hline 30 May & & & & & & & 1 & \\
\hline 03 Jun & & & 1 & & & & & \\
\hline 05 Jun & & & & 1 & & & & \\
\hline 13 Jun & & & & 1 & & & & \\
\hline 29 Jun & & & 1 & & & & & \\
\hline 01-Jul & & & & 1 & & & 1 & \\
\hline Totals & 43 & 110 & 14 & 4 & 2 & 5 & 3 & 0 \\
\hline
\end{tabular}


Appendix Table 15. Detections during 2008 of PIT-tagged smolts by date at four Snake River dams and three Columbia River dams for 247 wild Chinook salmon from Big Creek (lower) released 13-14 August 2007. Release sites were 487-488 km above Lower Granite Dam.

\begin{tabular}{|c|c|c|c|c|c|c|c|c|}
\hline \multirow{4}{*}{$\begin{array}{l}\text { Detection } \\
\text { date }\end{array}$} & \multicolumn{8}{|c|}{ Big Creek (lower) } \\
\hline & \multicolumn{2}{|c|}{ Lower Granite } & \multicolumn{6}{|c|}{ First detections } \\
\hline & First & & Little & Lower & Ice & & John & \\
\hline & detection & Expanded & Goose & Monumental & Harbor & McNary & Day & Bonneville \\
\hline $23 \mathrm{Apr}$ & 1 & 3 & & & & & & \\
\hline 29 Apr & 1 & 3 & & & & & & \\
\hline 01 May & 1 & 2 & & & & & & \\
\hline 02 May & 2 & 4 & & & & & & \\
\hline 03 May & 2 & 4 & & & & & & \\
\hline 04 May & 1 & 2 & & & & & & \\
\hline 06 May & 1 & 2 & 1 & & & & & \\
\hline 07 May & 1 & 2 & & & & & & \\
\hline 09 May & 1 & 2 & 3 & & & & & \\
\hline 10 May & 1 & 2 & 1 & & & & & \\
\hline 11 May & & & 1 & & & & & \\
\hline 12 May & 5 & 11 & & & 1 & & & \\
\hline 13 May & 1 & 2 & 1 & & & & & \\
\hline 14 May & 1 & 2 & & 1 & & & & \\
\hline 15 May & 2 & 5 & 1 & & & & & \\
\hline 17 May & 1 & 3 & & & & & & \\
\hline 18 May & 1 & 4 & & 1 & & & & \\
\hline 19 May & 1 & 4 & 2 & 1 & & & & \\
\hline 20 May & 1 & 6 & & & & & & \\
\hline 21 May & & & & 1 & 1 & & & \\
\hline 22 May & & & & 1 & & & 1 & \\
\hline 23 May & & & & 2 & & & & \\
\hline 28 May & & & & 1 & & & & \\
\hline 29 May & & & & 1 & & & & \\
\hline Totals & 25 & 64 & 10 & 9 & 2 & 0 & 1 & 0 \\
\hline
\end{tabular}


Appendix Table 16. Detections during 2008 of PIT-tagged smolts by date at four Snake River dams and three Columbia River dams for 628 wild Chinook salmon from Big Creek (upper) released 24 August 2007. Release sites were 535-536 km above Lower Granite Dam.

\begin{tabular}{|c|c|c|c|c|c|c|c|c|}
\hline \multirow[b]{3}{*}{$\begin{array}{l}\text { Detection } \\
\text { date }\end{array}$} & \multicolumn{8}{|c|}{ Big Creek (upper) } \\
\hline & \multicolumn{2}{|c|}{ Lower Granite } & \multirow{2}{*}{\multicolumn{2}{|c|}{$\begin{array}{c}\text { Lower } \\
\text { Monumental }\end{array}$}} & \multicolumn{2}{|c|}{ First detections } & \multirow[b]{2}{*}{ John } & \multirow[b]{2}{*}{ Bonneville } \\
\hline & $\begin{array}{c}\text { First } \\
\text { detection }\end{array}$ & Expanded & & & $\begin{array}{l}\text { Ice } \\
\text { Harbor }\end{array}$ & McNary & & \\
\hline $25 \mathrm{Apr}$ & 1 & 3 & & & & & & \\
\hline $30 \mathrm{Apr}$ & 1 & 3 & & & & & & \\
\hline 01 May & 1 & 2 & & & & & & \\
\hline 03 May & 1 & 2 & & & & & & \\
\hline 05 May & 3 & 6 & & & & & & \\
\hline 06 May & 2 & 4 & & & & & & \\
\hline 07 May & 3 & 6 & & & & & & \\
\hline 08 May & 5 & 10 & 2 & & & 1 & & \\
\hline 09 May & 1 & 2 & 2 & & & & & \\
\hline 10 May & 3 & 6 & 1 & & & & & \\
\hline 11 May & 5 & 10 & 1 & & & & & \\
\hline 12 May & 4 & 9 & 1 & & 2 & 1 & & \\
\hline 13 May & 3 & 6 & & 2 & & & & \\
\hline 14 May & & & & 1 & & 1 & & \\
\hline 16 May & & & 1 & & & & & \\
\hline 17 May & 2 & 6 & 2 & & & & & \\
\hline 18 May & 5 & 18 & 2 & & & 1 & & \\
\hline 19 May & 4 & 17 & 1 & 1 & & & & \\
\hline 20 May & 5 & 28 & & 1 & & & & \\
\hline 21 May & 3 & 14 & 6 & & & & & \\
\hline 22 May & 6 & 33 & 3 & 3 & 1 & & & \\
\hline 23 May & 1 & 6 & 3 & 4 & 1 & 3 & & \\
\hline 24 May & & & 2 & 1 & & 1 & & \\
\hline 25 May & & & 4 & 1 & 1 & & & \\
\hline 26 May & 1 & 4 & 2 & 2 & 1 & & & \\
\hline 27 May & & & & 1 & 1 & 1 & & 1 \\
\hline 28 May & & & 1 & 1 & & & 1 & \\
\hline 29 May & & & 1 & & & & & \\
\hline 30 May & 1 & 3 & 1 & 1 & & & & \\
\hline 01 Jun & & & & & & & 1 & \\
\hline 03 Jun & & & & & & & 1 & \\
\hline 04 Jun & & & & 2 & & & & \\
\hline 05 Jun & 1 & 4 & & & & & & \\
\hline Totals & 62 & 203 & 36 & 21 & 7 & 9 & 3 & 1 \\
\hline
\end{tabular}


Appendix Table 17. Daily and expanded detections (with estimated detection efficiencies) of PIT-tagged wild spring/summer Chinook salmon smolts from Idaho and Oregon at Lower Granite Dam during 2008, with associated river flows ( $\mathrm{kcfs})$, spill ( $\mathrm{kcfs})$, and water temperatures $\left({ }^{\circ} \mathrm{C}\right)$ at the dam.

\begin{tabular}{|c|c|c|c|c|c|c|c|}
\hline \multirow[b]{3}{*}{ Date } & \multirow[b]{3}{*}{$\begin{array}{c}\text { Average } \\
\text { flow (kcfs) }\end{array}$} & \multirow[b]{3}{*}{$\begin{array}{c}\text { Average } \\
\text { spill (kcfs) }\end{array}$} & \multirow{3}{*}{$\begin{array}{c}\text { Water } \\
\text { temperature } \\
\left({ }^{\circ} \mathrm{C}\right)\end{array}$} & \multicolumn{4}{|c|}{ Detections } \\
\hline & & & & \multicolumn{2}{|c|}{ Idaho only } & \multicolumn{2}{|c|}{ Idaho and Oregon } \\
\hline & & & & $\begin{array}{c}\text { Total } \\
\text { number }\end{array}$ & $\begin{array}{c}\text { Expanded } \\
\text { number }\end{array}$ & $\begin{array}{c}\text { Total } \\
\text { number }\end{array}$ & $\begin{array}{l}\text { Expanded } \\
\text { number* }\end{array}$ \\
\hline $01 \mathrm{Apr}$ & 42.7 & 0 & 6.3 & 0 & 0 & 0 & 0 \\
\hline $02 \mathrm{Apr}$ & 38.9 & 0 & 6.0 & 0 & 0 & 0 & 0 \\
\hline $03 \mathrm{Apr}$ & 45.0 & 20.6 & 6.1 & 0 & 0 & 0 & 0 \\
\hline $04 \mathrm{Apr}$ & 42.5 & 20.4 & 6.3 & 0 & 0 & 0 & 0 \\
\hline $05 \mathrm{Apr}$ & 44.7 & 20.3 & 6.5 & 0 & 0 & 0 & 0 \\
\hline $06 \mathrm{Apr}$ & 45.3 & 20.3 & 6.8 & 0 & 0 & 0 & 0 \\
\hline $07 \mathrm{Apr}$ & 43.5 & 20.3 & 6.9 & 0 & 0 & 0 & 0 \\
\hline $08 \mathrm{Apr}$ & 47.8 & 20.3 & 7.0 & 0 & 0 & 0 & 0 \\
\hline 09 Apr & 46.3 & 20.4 & 7.3 & 0 & 0 & 0 & 0 \\
\hline $10 \mathrm{Apr}$ & 46.1 & 20.3 & 7.4 & 0 & 0 & 1 & $3(0.300)$ \\
\hline $11 \mathrm{Apr}$ & 44.2 & 20.3 & 7.6 & 0 & 0 & 0 & 0 \\
\hline $12 \mathrm{Apr}$ & 45.5 & 20.2 & 8.0 & 0 & 0 & 0 & 0 \\
\hline $13 \mathrm{Apr}$ & 43.6 & 20.1 & 8.1 & 0 & 0 & 0 & 0 \\
\hline $14 \mathrm{Apr}$ & 54.7 & 20.2 & 8.0 & 0 & 0 & 1 & $4(0.275)$ \\
\hline 15 Apr & 63.6 & 20.4 & 8.3 & 0 & 0 & 0 & 0 \\
\hline $16 \mathrm{Apr}$ & 62.7 & 20.3 & 8.9 & 0 & 0 & 1 & $4(0.260)$ \\
\hline 17 Apr & 61.8 & 20.2 & 8.9 & 0 & 0 & 5 & $17(0.288)$ \\
\hline $18 \mathrm{Apr}$ & 63.0 & 20.3 & 8.3 & 0 & 0 & 5 & $16(0.310)$ \\
\hline 19 Apr & 65.1 & 20.6 & 8.1 & 0 & 0 & 1 & $3(0.330)$ \\
\hline $20 \mathrm{Apr}$ & 66.6 & 20.5 & 8.4 & 0 & 0 & 3 & $8(0.361)$ \\
\hline $21 \mathrm{Apr}$ & 65.9 & 20.5 & 8.6 & 1 & 3 & 4 & $11(0.363)$ \\
\hline $22 \mathrm{Apr}$ & 57.9 & 20.5 & 8.4 & 0 & 0 & 2 & $6(0.355)$ \\
\hline $23 \mathrm{Apr}$ & 51.5 & 20.3 & 7.9 & 5 & 15 & 11 & $32(0.341)$ \\
\hline $24 \mathrm{Apr}$ & 53.9 & 20.4 & 7.8 & 4 & 11 & 4 & $11(0.363)$ \\
\hline $25 \mathrm{Apr}$ & 60.2 & 20.4 & 7.9 & 7 & 20 & 12 & $32(0.373)$ \\
\hline $26 \mathrm{Apr}$ & 56.1 & 20.4 & 8.4 & 3 & 9 & 4 & $11(0.348)$ \\
\hline $27 \mathrm{Apr}$ & 58.3 & 20.3 & 8.6 & 4 & 12 & 4 & $11(0.360)$ \\
\hline $28 \mathrm{Apr}$ & 55.2 & 20.2 & 8.6 & 3 & 9 & 5 & 13 (0.377) \\
\hline $29 \mathrm{Apr}$ & 67.2 & 20.4 & 9.0 & 9 & 27 & 11 & $31(0.354)$ \\
\hline $30 \mathrm{Apr}$ & 71.2 & 20.4 & 9.5 & 13 & 39 & 18 & $55(0.330)$ \\
\hline 01 May & 67.7 & 20.4 & 10.1 & 13 & 30 & 25 & $59(0.422)$ \\
\hline 02 May & 63.5 & 20.4 & 9.9 & 15 & 32 & 25 & $55(0.452)$ \\
\hline 03 May & 62.3 & 20.3 & 9.1 & 14 & 28 & 18 & $39(0.464)$ \\
\hline 04 May & 63.2 & 20.3 & 9.1 & 14 & 29 & 25 & $54(0.460)$ \\
\hline 05 May & 74.0 & 20.2 & 9.6 & 21 & 42 & 31 & $64(0.481)$ \\
\hline 06 May & 83.9 & 20.1 & 10.1 & 39 & 82 & 54 & $113(0.476)$ \\
\hline 07 May & 87.5 & 20.3 & 10.6 & 51 & 99 & 66 & $129(0.513)$ \\
\hline 08 May & 101.2 & 32.8 & 10.6 & 30 & 60 & 46 & $92(0.500)$ \\
\hline 09 May & 97.8 & 28.6 & 10.2 & 24 & 48 & 30 & $57(0.528)$ \\
\hline 10 May & 93.4 & 24.2 & 9.8 & 31 & 62 & 41 & 79 (0.519) \\
\hline
\end{tabular}


Appendix Table 17. Continued.

\begin{tabular}{|c|c|c|c|c|c|c|c|}
\hline \multirow[b]{3}{*}{ Date } & \multirow[b]{3}{*}{$\begin{array}{c}\text { Average } \\
\text { flow (kcfs) }\end{array}$} & \multirow[b]{3}{*}{$\begin{array}{c}\text { Average } \\
\text { spill (kcfs) }\end{array}$} & \multirow[b]{3}{*}{$\begin{array}{c}\text { water } \\
\text { temperature }\end{array}$} & \multicolumn{4}{|c|}{ Detections } \\
\hline & & & & \multicolumn{2}{|c|}{ Idaho only } & \multicolumn{2}{|c|}{ Idaho and Oregon } \\
\hline & & & & $\begin{array}{c}\text { Total } \\
\text { number }\end{array}$ & $\begin{array}{c}\text { Expanded } \\
\text { number }\end{array}$ & $\begin{array}{c}\text { Total } \\
\text { number }\end{array}$ & $\begin{array}{c}\text { Expanded } \\
\text { number* }\end{array}$ \\
\hline 11 May & 89.5 & 20.5 & 9.8 & 35 & 70 & 56 & $110(0.509)$ \\
\hline 12 May & 88.5 & 20.7 & 9.7 & 34 & 77 & 41 & $93(0.440)$ \\
\hline 13 May & 87.0 & 20.7 & 9.8 & 33 & 69 & 35 & $75(0.466)$ \\
\hline 14 May & 76.4 & 20.6 & 9.8 & 18 & 41 & 25 & $57(0.436)$ \\
\hline 15 May & 79.9 & 20.5 & 10.0 & 10 & 23 & 15 & $37(0.403)$ \\
\hline 16 May & 97.4 & 27.6 & 10.2 & 13 & 37 & 19 & $52(0.363)$ \\
\hline 17 May & 121.9 & 51.2 & 10.6 & 15 & 45 & 16 & $49(0.329)$ \\
\hline 18 May & 149.5 & 78.2 & 11.3 & 27 & 98 & 31 & $112(0.278)$ \\
\hline 19 May & 177.5 & 105.4 & 11.0 & 18 & 74 & 23 & $96(0.240)$ \\
\hline 20 May & 197.3 & 125.8 & 10.3 & 16 & 91 & 22 & $122(0.180)$ \\
\hline 21 May & 198.9 & 128.6 & 9.6 & 8 & 39 & 10 & $48(0.210)$ \\
\hline 22 May & 182.4 & 112.0 & 9.0 & 12 & 64 & 14 & $77(0.182)$ \\
\hline 23 May & 154.4 & 85.0 & 8.7 & 9 & 54 & 10 & $60(0.168)$ \\
\hline 24 May & 135.4 & 68.7 & 8.8 & 2 & 10 & 2 & $10(0.208)$ \\
\hline 25 May & 130.1 & 59.7 & 9.4 & 3 & 12 & 3 & $13(0.234)$ \\
\hline 26 May & 127.3 & 56.4 & 10.2 & 4 & 16 & 5 & $21(0.243)$ \\
\hline 27 May & 130.6 & 60.4 & 10.7 & 2 & 8 & 2 & $7(0.275)$ \\
\hline 28 May & 131.3 & 61.4 & 10.9 & 1 & 4 & 1 & $4(0.260)$ \\
\hline 29 May & 144.6 & 74.9 & 10.9 & 4 & 17 & 8 & $34(0.235)$ \\
\hline 30 May & 151.7 & 80.3 & 10.8 & 1 & 3 & 1 & $3(0.292)$ \\
\hline 31 May & 152.9 & 82.3 & 10.7 & 1 & 4 & 1 & $4(0.269)$ \\
\hline 01 Jun & 154.3 & 83.4 & 11.0 & 0 & 0 & 3 & $11(0.268)$ \\
\hline 02 Jun & 158.9 & 87.6 & 11.2 & 3 & 9 & 4 & $11(0.348)$ \\
\hline 03 Jun & 160.7 & 89.0 & 11.2 & 2 & 8 & 3 & $11(0.262)$ \\
\hline 04 Jun & 152.2 & 81.9 & 10.6 & 3 & 9 & 3 & $10(0.295)$ \\
\hline 05 Jun & 149.4 & 78.9 & 10.2 & 1 & 4 & 3 & $11(0.265)$ \\
\hline 06 Jun & 140.1 & 69.5 & 10.1 & 1 & 3 & 1 & $3(0.346)$ \\
\hline 07 Jun & 138.7 & 68.1 & 10.5 & 0 & 0 & 0 & 0 \\
\hline 08 Jun & 125.1 & 55.4 & 10.8 & 0 & 0 & 0 & 0 \\
\hline 09 Jun & 121.6 & 52.2 & 10.8 & 0 & 0 & 2 & $12(0.165)$ \\
\hline 10 Jun & 120.8 & 51.1 & 11.1 & 1 & 3 & 1 & $3(0.288)$ \\
\hline 11 Jun & 122.4 & 60.0 & 11.3 & 0 & 0 & 2 & $12(0.170)$ \\
\hline 12 Jun & 124.2 & 55.9 & 11.1 & 0 & 0 & 1 & $3(0.292)$ \\
\hline 13 Jun & 125.2 & 43.6 & 10.5 & 0 & 0 & 0 & 0 \\
\hline 14 Jun & 118.0 & 29.4 & 11.0 & 0 & 0 & 1 & $3(0.356)$ \\
\hline 15 Jun & 116.5 & 27.5 & 11.8 & 0 & 0 & 0 & 0 \\
\hline 16 Jun & 118.1 & 37.9 & 12.6 & 1 & 3 & 1 & $3(0.390)$ \\
\hline 17 Jun & 130.7 & 60.0 & 13.1 & 0 & 0 & 0 & 0 \\
\hline 18 Jun & 131.9 & 67.8 & 13.5 & 0 & 0 & 0 & 0 \\
\hline 19 Jun & 133.0 & 65.6 & 13.5 & 0 & 0 & 0 & 0 \\
\hline 20 Jun & 130.9 & 60.3 & 13.1 & 0 & 0 & 0 & 0 \\
\hline 21 Jun & 130.1 & 59.2 & 13.1 & 0 & 0 & 0 & 0 \\
\hline 22 Jun & 133.9 & 64.4 & 13.4 & 0 & 0 & 0 & 0 \\
\hline
\end{tabular}


Appendix Table 17. Continued.

\begin{tabular}{lccccccc}
\hline & & & \multicolumn{5}{c}{ Detections } \\
\cline { 5 - 8 } & & & & Idaho only & Idaho and Oregon \\
\cline { 5 - 8 } Date & $\begin{array}{c}\text { Average } \\
\text { flow (kcfs) }\end{array}$ & $\begin{array}{c}\text { Average } \\
\text { spill (kcfs) }\end{array}$ & $\begin{array}{c}\text { water } \\
\text { temperature }\end{array}$ & $\begin{array}{c}\text { Total } \\
\text { number }\end{array}$ & $\begin{array}{c}\text { Expanded } \\
\text { number }\end{array}$ & $\begin{array}{c}\text { Total } \\
\text { number }\end{array}$ & $\begin{array}{c}\text { Expanded } \\
\text { number* }\end{array}$ \\
\hline 23 Jun & 139.5 & 69.9 & 13.5 & 0 & 0 & 0 & 0 \\
24 Jun & 132.1 & 63.7 & 13.7 & 0 & 0 & 0 & 0 \\
25 Jun & 120.0 & 47.1 & 13.5 & 0 & 0 & 1 & $7(0.143)$ \\
26 Jun & 112.5 & 40.9 & 13.8 & 0 & 0 & 0 & 0 \\
27 Jun & 101.7 & 34.6 & 14.1 & 0 & 0 & 0 & 0 \\
28 Jun & 100.2 & 28.8 & 14.5 & 0 & 0 & 0 & 0 \\
29 Jun & 103.5 & 18.3 & 14.9 & 0 & 0 & 0 & 0 \\
30 Jun & 107.0 & 21.1 & 15.3 & 0 & 0 & 0 & 0 \\
01 Jul & 104.6 & 23.5 & 15.7 & 0 & 0 & 0 & 0 \\
02 Jul & 102.1 & 18.3 & 15.9 & 0 & 0 & 1 & $9(0.108)$ \\
03 Jul & 96.6 & 18.3 & 15.7 & 0 & 0 & 0 & 0 \\
04 Jul & 87.9 & 18.3 & 15.7 & 0 & 0 & 0 & 0 \\
05 Jul & 80.8 & 18.3 & 16.1 & 0 & 0 & 0 & 0 \\
06 Jul & 73.0 & 18.2 & 16.3 & 0 & 0 & 0 & 0 \\
07 Jul & 66.8 & 18.3 & 16.4 & 0 & 0 & 0 & 0 \\
08 Jul & 66.9 & 18.4 & 16.7 & 0 & 0 & 0 & 0 \\
\hline
\end{tabular}

* Estimated detection efficiency in parenthesis. 
Appendix Table 18. Daily first-time detections of PIT-tagged wild spring/summer Chinook salmon smolts from Idaho at Little Goose Dam during 2008, with associated river flows ( $\mathrm{kcfs})$, spill ( $\mathrm{kcfs}$ ), and water temperatures $\left({ }^{\circ} \mathrm{C}\right)$ at the dam.

\begin{tabular}{|c|c|c|c|c|}
\hline Date & Average flow (kcfs) & Average spill (kcfs) & $\begin{array}{c}\text { Water } \\
\text { temperature }\left({ }^{\circ} \mathrm{C}\right)\end{array}$ & Numbers detected \\
\hline $28 \mathrm{Apr}$ & 54.9 & 22.6 & 8.8 & 1 \\
\hline 29 Apr & 65.6 & 25.7 & 8.8 & 1 \\
\hline 01 May & 66.1 & 27.9 & 9.2 & 1 \\
\hline 03 May & 62.1 & 29.1 & 9.7 & 7 \\
\hline 04 May & 63.1 & 29.0 & 10.2 & 1 \\
\hline 06 May & 82.0 & 31.3 & 10.8 & 3 \\
\hline 07 May & 84.8 & 31.1 & 10.3 & 4 \\
\hline 08 May & 100.7 & 34.6 & 10.3 & 15 \\
\hline 09 May & 95.2 & 32.2 & 10.7 & 14 \\
\hline 10 May & 91.6 & 27.4 & 10.9 & 14 \\
\hline 11 May & 86.9 & 23.8 & 10.9 & 17 \\
\hline 12 May & 86.8 & 23.8 & 10.5 & 15 \\
\hline 13 May & 85.2 & 25.6 & 10.2 & 10 \\
\hline 14 May & 74.3 & 22.1 & 10.3 & 7 \\
\hline 15 May & 77.3 & 23.1 & 10.2 & 6 \\
\hline 16 May & 97.3 & 26.1 & 10.3 & 8 \\
\hline 17 May & 117.8 & 35.7 & 10.7 & 10 \\
\hline 18 May & 144.8 & 53.6 & 11.1 & 15 \\
\hline 19 May & 172.5 & 81.1 & 11.6 & 16 \\
\hline 20 May & 186.9 & 96.7 & 11.6 & 15 \\
\hline 21 May & 186.4 & 96.0 & 10.8 & 22 \\
\hline 22 May & 178.1 & 86.8 & 10.1 & 15 \\
\hline 23 May & 152.3 & 62.2 & 9.6 & 19 \\
\hline 24 May & 133.3 & 52.8 & 9.5 & 7 \\
\hline 25 May & 124.8 & 39.4 & 9.3 & 7 \\
\hline 26 May & 122.4 & 36.1 & 9.5 & 7 \\
\hline 27 May & 124.8 & 36.7 & 10.0 & 4 \\
\hline 28 May & 126.2 & 44.1 & 10.8 & 9 \\
\hline 29 May & 140.3 & 53.4 & 11.4 & 2 \\
\hline 30 May & 146.3 & 65.4 & 11.6 & 3 \\
\hline 31 May & 149.0 & 58.0 & 11.6 & 6 \\
\hline 01 Jun & 150.0 & 59.2 & 11.6 & 5 \\
\hline 03 Jun & 155.0 & 66.6 & 11.5 & 3 \\
\hline 04 Jun & 148.9 & 66.6 & 11.6 & 5 \\
\hline 06 Jun & $133 . .6$ & 42.4 & 10.9 & 2 \\
\hline 07 Jun & 132.1 & 40.8 & 10.6 & 1 \\
\hline 08 Jun & 119.9 & 36.0 & 10.6 & 2 \\
\hline 11 Jun & 116.4 & 49.6 & 11.0 & 4 \\
\hline 13 Jun & 120.0 & 45.5 & 11.9 & 1 \\
\hline 23 Jun & 132.7 & 41.7 & 13.6 & 1 \\
\hline 29 Jun & 101.7 & 29.5 & 14.6 & 1 \\
\hline
\end{tabular}


Appendix Table 19. Daily first-time detections of PIT-tagged wild spring/summer Chinook salmon smolts from Idaho at Lower Monumental Dam during 2008, with associated river flows (kcfs), spill (kcfs), and water temperatures $\left({ }^{\circ} \mathrm{C}\right)$ at the dam.

\begin{tabular}{|c|c|c|c|c|}
\hline Date & Average flow (kcfs) & Average spill (kcfs) & $\begin{array}{c}\text { Water } \\
\text { temperature }\left({ }^{\circ} \mathrm{C}\right)\end{array}$ & Numbers detected \\
\hline $30 \mathrm{Apr}$ & 68.6 & 21.5 & 9.4 & 1 \\
\hline 01 May & 66.3 & 22.5 & 9.0 & 1 \\
\hline 04 May & 61.2 & 23.8 & 9.6 & 1 \\
\hline 06 May & 79.5 & 20.6 & 10.4 & 2 \\
\hline 07 May & 86.6 & 19.7 & 11.0 & 4 \\
\hline 08 May & 100.8 & 21.5 & 10.7 & 5 \\
\hline 09 May & 94.1 & 24.5 & 10.5 & 5 \\
\hline 10 May & 90.7 & 26.6 & 10.7 & 1 \\
\hline 11 May & 85.1 & 27.9 & 11.0 & 1 \\
\hline 12 May & 87.6 & 26.2 & 11.1 & 4 \\
\hline 13 May & 83.5 & 22.8 & 11.0 & 7 \\
\hline 14 May & 71.9 & 24.0 & 10.8 & 5 \\
\hline 15 May & 77.9 & 26.7 & 10.6 & 1 \\
\hline 16 May & 96.4 & 27.2 & 10.7 & 1 \\
\hline 17 May & 116.7 & 25.6 & 11.0 & 4 \\
\hline 18 May & 147.0 & 32.4 & 11.3 & 4 \\
\hline 19 May & 182.7 & 68.6 & 11.6 & 7 \\
\hline 20 May & 198.8 & 85.6 & 12.0 & 10 \\
\hline 21 May & 197.2 & 85.7 & 11.6 & 10 \\
\hline 22 May & 189.7 & 79.2 & 10.8 & 11 \\
\hline 23 May & 154.9 & 43.7 & 10.3 & 12 \\
\hline 24 May & 137.2 & 42.9 & 10.0 & 8 \\
\hline 25 May & 124.5 & 26.7 & 9.9 & 1 \\
\hline 26 May & 122.7 & 25.2 & 9.9 & 5 \\
\hline 27 May & 125.5 & 25.3 & 10.0 & 7 \\
\hline 28 May & 127.3 & 37.9 & 10.4 & 3 \\
\hline 29 May & 142.1 & 40.7 & 11.1 & 4 \\
\hline 30 May & 150.2 & 47.1 & 11.7 & 4 \\
\hline 01 Jun & 152.9 & 57.1 & 12.0 & 1 \\
\hline 03 Jun & 158.9 & 58.2 & 11.7 & 1 \\
\hline 04 Jun & 156.1 & 62.8 & 11.7 & 4 \\
\hline 05 Jun & 147.2 & 32.2 & 11.8 & 4 \\
\hline 06 Jun & 136.4 & 28.0 & 11.6 & 2 \\
\hline 08 Jun & 123.7 & 34.2 & 10.9 & 2 \\
\hline 13 Jun & 122.6 & 39.6 & 11.7 & 1 \\
\hline 18 Jun & 133.7 & 43.4 & 12.4 & 1 \\
\hline $01 \mathrm{Jul}$ & 102.7 & 14.8 & 15.3 & 1 \\
\hline
\end{tabular}


Appendix Table 20. Daily first-time detections of PIT-tagged wild spring/summer Chinook salmon smolts from Idaho at Ice Harbor Dam during 2008, with associated river flows (kcfs), spill (kcfs), and water temperatures $\left({ }^{\circ} \mathrm{C}\right)$ at the dam.

\begin{tabular}{lcccc}
\hline Date & $\begin{array}{c}\text { Average } \\
\text { flow }(\mathrm{kcfs})\end{array}$ & $\begin{array}{c}\text { Average } \\
\text { Spill }(\mathrm{kcfs})\end{array}$ & $\begin{array}{c}\text { Water } \\
\text { temperature }\left({ }^{\circ} \mathrm{C}\right)\end{array}$ & $\begin{array}{c}\text { Numbers } \\
\text { detected }\end{array}$ \\
\hline 06 May & 81.0 & 30.6 & 10.3 & 1 \\
07 May & 88.0 & 26.2 & 10.6 & 1 \\
08 May & 105.3 & 54.1 & 11.1 & 1 \\
10 May & 95.2 & 39.3 & 11.0 & 2 \\
11 May & 87.0 & 26.2 & 10.9 & 1 \\
12 May & 91.3 & 28.2 & 11.0 & 3 \\
17 May & 120.4 & 53.3 & 11.5 & 2 \\
18 May & 149.3 & 78.7 & 11.6 & 4 \\
20 May & 198.8 & 129.9 & 11.9 & 2 \\
21 May & 199.0 & 131.3 & 12.0 & 4 \\
22 May & 193.4 & 126.0 & 11.6 & 9 \\
23 May & 163.1 & 96.2 & 11.1 & 3 \\
24 May & 143.9 & 94.0 & 10.7 & 3 \\
25 May & 130.7 & 78.2 & 10.6 & 2 \\
26 May & 127.8 & 68.3 & 10.4 & 1 \\
27 May & 133.3 & 66.2 & 10.6 & 1 \\
28 May & 133.2 & 77.4 & 10.5 & 1 \\
30 May & 156.6 & 94.6 & 11.5 & 1 \\
03 Jun & 162.8 & 99.3 & 12.1 & 1 \\
04 Jun & 162.1 & 99.6 & 11.9 & 1 \\
08 Jun & 130.2 & 63.1 & 11.6 & 12.2 \\
14 Jun & 120.5 & 38.4 & 12.8 & \\
16 Jun & 119.9 & 61.5 & & \\
\hline
\end{tabular}


Appendix Table 21. Daily first-time detections of PIT-tagged wild spring/summer Chinook salmon smolts from Idaho at McNary Dam during 2008, with associated river flows ( $\mathrm{kcfs})$, spill (kcfs), and water temperatures $\left({ }^{\circ} \mathrm{C}\right)$ at the dam.

\begin{tabular}{|c|c|c|c|c|}
\hline Date & Average flow (kcfs) & Average spill (kcfs) & $\begin{array}{c}\text { Water } \\
\text { temperature }\left({ }^{\circ} \mathrm{C}\right)\end{array}$ & Numbers detected \\
\hline 08 May & 239.8 & 96.4 & 10.8 & 2 \\
\hline 10 May & 268.1 & 107.6 & 11.1 & 2 \\
\hline 11 May & 224.1 & 89.7 & 11.1 & 1 \\
\hline 12 May & 275.7 & 110.6 & 10.9 & 4 \\
\hline 13 May & 265.6 & 107.0 & 11.0 & 1 \\
\hline 14 May & 252.6 & 101.5 & 11.0 & 4 \\
\hline 15 May & 253.1 & 101.5 & 11.3 & 2 \\
\hline 17 May & 265.7 & 106.6 & 12.3 & 4 \\
\hline 18 May & 341.3 & 165.3 & 12.6 & 3 \\
\hline 19 May & 385.0 & 210.2 & 12.7 & 1 \\
\hline 22 May & 393.5 & 221.3 & 12.1 & 1 \\
\hline 23 May & 370.0 & 197.8 & 12.1 & 4 \\
\hline 24 May & 377.3 & 209.1 & 12.1 & 2 \\
\hline 25 May & 375.2 & 218.7 & 11.9 & 2 \\
\hline 27 May & 367.4 & 196.6 & 12.0 & 1 \\
\hline 28 May & 390.9 & 222.0 & 12.0 & 2 \\
\hline 29 May & 393.1 & 220.3 & 12.1 & 1 \\
\hline 02 Jun & 391.3 & 219.0 & 13.4 & 1 \\
\hline 03 Jun & 400.1 & 230.7 & 13.3 & 1 \\
\hline 04 Jun & 424.0 & 250.3 & 13.1 & 1 \\
\hline 06 Jun & 388.3 & 213.7 & 12.9 & 1 \\
\hline 09 Jun & 329.6 & 154.2 & 12.8 & 1 \\
\hline 11 Jun & 384.1 & 223.9 & 12.6 & 1 \\
\hline 23 Jun & 301.1 & 166.8 & 15.3 & 1 \\
\hline 27 Jun & 354.4 & 183.1 & 15.5 & 1 \\
\hline
\end{tabular}


Appendix Table 22. Daily first-time detections of PIT-tagged wild spring/summer Chinook salmon smolts from Idaho at John Day Dam during 2008, with associated river flows ( $\mathrm{kcfs})$, spill ( $\mathrm{kcfs})$, and water temperatures $\left({ }^{\circ} \mathrm{C}\right)$ at the dam.

\begin{tabular}{lcccc}
\hline & & & & Water \\
Date & Average flow (kcfs) & Average spill $(\mathrm{kcfs})$ & $\begin{array}{c}\text { Nemperature }\left({ }^{\circ} \mathrm{C}\right) \\
\text { Numbers detected }\end{array}$ \\
\hline 16 May & 270.4 & 81.1 & 12.5 & 1 \\
18 May & 349.3 & 110.6 & 12.7 & 1 \\
19 May & 387.5 & 133.5 & 13.1 & 1 \\
20 May & 385.9 & 125.1 & 13.4 & 3 \\
21 May & 414.9 & 123.6 & 13.5 & 2 \\
22 May & 409.4 & 137.3 & 13.2 & 3 \\
23 May & 396.0 & 143.0 & 12.9 & 1 \\
24 May & 388.5 & 154.6 & 12.7 & 1 \\
25 May & 393.2 & 139.7 & 12.8 & 3 \\
27 May & 365.0 & 111.0 & 13.1 & 2 \\
28 May & 394.9 & 137.8 & 13.0 & 6 \\
29 May & 399.1 & 137.3 & 12.8 & 3 \\
30 May & 413.9 & 129.9 & 12.8 & 1 \\
31 May & 412.9 & 124.3 & 12.8 & 2 \\
01 Jun & 394.2 & 126.6 & 12.8 & 1 \\
03 Jun & 417.8 & 150.9 & 13.4 & 1 \\
04 Jun & 417.1 & 178.6 & 13.5 & 1 \\
06 Jun & 395.9 & 135.0 & 13.4 & 1 \\
10 Jun & 346.0 & 126.8 & 13.1 & 1 \\
02 Jul & 320.7 & 96.3 & 17.2 & \\
\hline
\end{tabular}


Appendix Table 23. Daily first-time detections of PIT-tagged wild spring/summer Chinook salmon smolts from Idaho at Bonneville Dam during 2008, with associated river flows (kcfs), spill (kcfs), and water temperatures $\left({ }^{\circ} \mathrm{C}\right)$ at the dam. The table includes 1 first-time detection from the PIT-tag trawl near the mouth of the Columbia River (TWX).

\begin{tabular}{lcccc}
\hline Date & Average flow $(\mathrm{kcfs})$ & Average spill $(\mathrm{kcfs})$ & $\begin{array}{c}\text { Water } \\
\text { temperature }\left({ }^{\circ} \mathrm{C}\right)\end{array}$ & Numbers detected \\
\hline 13 May & 297.8 & 97.4 & 11.4 & 1 \\
19 May & 402.4 & 195.5 & 13.2 & 1 \\
22 May & 418.6 & 230.9 & 13.2 & 1 \\
23 May & 415.2 & 217.3 & 13.0 & 2 \\
24 May & 399.2 & 192.7 & 12.9 & 1 \\
25 May & 397.5 & 189.8 & 12.9 & 1 \\
30 May & 410.8 & 202.9 & 13.1 & 1 \\
15 Jun & 316.3 & 119.3 & 13.6 & 1 \\
20 Jun & 357.6 & 141.0 & 15.3 & 1 \\
07 Jul & 272.0 & 85.5 & 18.1 & 1 \\
TWX & & & & \\
15 May & & & & \\
\hline
\end{tabular}


Appendix Table 24. Monthly environmental data collected from Marsh Creek (rkm 179.5 from the mouth of the Middle Fork Salmon River) from August 2007 through July 2008.

\begin{tabular}{lcccccccccccc}
\hline & Aug & Sept & Oct & Nov & Dec & Jan & Feb & Mar & Apr & May & Jun & Jul \\
\hline & & & & \multicolumn{7}{c}{ Temperature $\left({ }^{\circ} \mathrm{C}\right)$} \\
Min. & 6.2 & 1.9 & 1.2 & -0.1 & -0.1 & 0.0 & -0.1 & -0.1 & 0.0 & 0.0 & 2.4 & 6.2 \\
Max. & 19.1 & 17.7 & 10.5 & 4.0 & 2.9 & 0.0 & 5.5 & 6.4 & 10.1 & 12.3 & 16.4 & 18.3 \\
Ave. & 11.9 & 8.4 & 4.8 & 0.9 & 0.3 & 0.0 & 0.9 & 1.7 & 2.9 & 4.4 & 8.0 & 12.1
\end{tabular}

Dissolved oxygen (ppm)

$\begin{array}{lllllllllllll}\text { Min. } & 9.0 & --- & --- & --- & --- & --- & --- & --- & 7.5 & 6.4 & 6.6 & 6.5 \\ \text { Max. } & 11.5 & --- & --- & --- & --- & --- & --- & --- & 11.8 & 9.6 & 9.3 & 9.2 \\ \text { Ave. } & 10.3 & --- & --- & --- & --- & --- & --- & --- & 8.6 & 8.1 & 8.0 & 7.6\end{array}$

Specific conductance $(\mu \mathrm{S} / \mathrm{cm})$

$\begin{array}{lllllllllllll}\text { Min. } & 50.0 & 62.0 & 44.0 & 39.0 & 47.0 & 54.0 & 52.0 & 51.0 & 46.0 & 28.0 & 28.0 & 39.0\end{array}$

$\begin{array}{llllllllllllll}\text { Max. } & 66.0 & 67.0 & 65.0 & 58.0 & 61.0 & 63.0 & 60.0 & 62.0 & 80.0 & 54.0 & 39.0 & 52.0\end{array}$

$\begin{array}{lllllllllllll}\text { Ave. } & 61.7 & 64.4 & 61.7 & 52.8 & 56.9 & 58.6 & 57.1 & 57.7 & 55.9 & 37.6 & 32.3 & 46.4\end{array}$

$\underline{\text { Turbidity (ntu) }}$

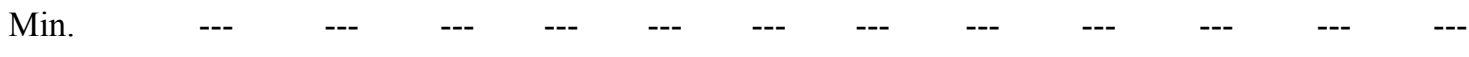

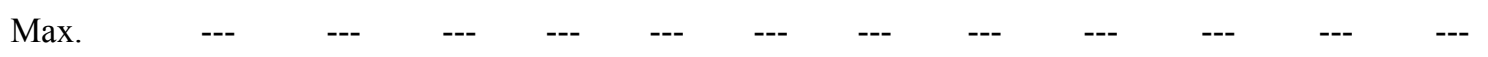

Ave.

Depth (ft)

$\begin{array}{lllllllllllll}\text { Min. } & 0.6 & 0.3 & 0.2 & 0.4 & 0.3 & 0.6 & 0.3 & 0.1 & 0.3 & 1.4 & 2.4 & 1.6\end{array}$

$\begin{array}{lllllllllllll}\text { Max. } & 1.1 & 1.0 & 2.6 & 1.4 & 2.5 & 2.6 & 2.9 & 1.3 & 1.7 & 3.9 & 3.3 & 2.6\end{array}$

$\begin{array}{lllllllllllll}\text { Ave. } & 0.8 & 0.7 & 0.8 & 1.0 & 1.1 & 1.8 & 1.2 & 0.7 & 1.0 & 2.6 & 2.8 & 1.9\end{array}$

\begin{tabular}{lllllllllllll} 
& & & \multicolumn{1}{c}{$\mathrm{pH}$} & & & & \\
Min. & 7.3 & 7.3 & 6.8 & 7.3 & 7.5 & 7.4 & 7.6 & 7.7 & 7.0 & 6.4 & 6.8 & 7.0 \\
Max. & 8.4 & 8.7 & 8.5 & 8.1 & 8.6 & 7.8 & 8.2 & 8.2 & 8.2 & 7.7 & 7.9 & 8.4 \\
Ave. & 7.6 & 7.7 & 7.6 & 7.7 & 7.7 & 7.6 & 7.8 & 7.9 & 7.5 & 6.9 & 7.1 & 7.5 \\
\hline
\end{tabular}


Appendix Table 25. Monthly environmental data collected from the Salmon River near Sawtooth Hatchery (rkm 627.9) from August 2007 through July 2008.

\begin{tabular}{lcccccccccccc}
\hline & Aug & Sept & Oct & Nov & Dec & Jan & Feb & Mar & Apr & May & Jun & Jul \\
\hline & & & \multicolumn{1}{c}{ Temperature $\left({ }^{\circ} \mathrm{C}\right)$} \\
Min. & 8.4 & 4.2 & 2.7 & -0.1 & -0.1 & -0.1 & -0.1 & -0.1 & 0.0 & 1.4 & 4.9 & 9.4 \\
Max. & 20.5 & 19.3 & 11.4 & 7.0 & 4.2 & 2.2 & 5.7 & 7.8 & 11.2 & 12.8 & 18.2 & 19.5 \\
Ave. & 13.8 & 10.7 & 6.5 & 3.0 & 0.8 & 0.2 & 1.7 & 3.1 & 5.0 & 7.0 & 10.5 & 14.5
\end{tabular}

Dissolved oxygen (ppm)

$\begin{array}{lcccccccccccc}\text { Min. } & 8.5 & --- & --- & 9.7 & 8.6 & 11.0 & 8.7 & 9.2 & --- & --- & -- & --- \\ \text { Max. } & 14.1 & --- & --- & 13.7 & 14.7 & 14.8 & 14.8 & 14.9 & --- & --- & --- & --- \\ \text { Ave. } & 10.9 & --- & --- & 11.3 & 12.5 & 13.5 & 13.4 & 13.4 & --- & --- & --- & ---\end{array}$

Specific conductance $(\mu \mathrm{S} / \mathrm{cm})$

$\begin{array}{lcccccccccccc}\text { Min. } & --- & --- & --- & 102.0 & 107.0 & 109.0 & 112.0 & 112.0 & 112.0 & 61.0 & 53.0 & 59.0 \\ \text { Max. } & --- & --- & --- & 122.0 & 130.0 & 130.0 & 160.0 & 160.0 & 160.0 & 148.0 & 86.0 & 112.0 \\ \text { Ave. } & --- & --- & --- & 112.1 & 118.3 & 116.5 & 119.0 & 136.6 & 136.6 & 90.2 & 67.3 & 87.5\end{array}$

Turbidity (ntu)

$\begin{array}{lcccccccccccc}\text { Min. } & 1.3 & --- & --- & -- & --- & -- & --- & --- & --- & --- & --- & --- \\ \text { Max. } & 145.3 & --- & --- & --- & --- & --- & --- & --- & --- & --- & --- & --- \\ \text { Ave. } & 3.6 & --- & --- & --- & --- & --- & --- & --- & --- & --- & --- & ---\end{array}$

Depth (ft)

$\begin{array}{lllllllllllll}\text { Min. } & 1.4 & --- & --- & 0.6 & 0.5 & 0.0 & 0.3 & 0.5 & 0.6 & 1.9 & 2.5 & 2.0\end{array}$

$\begin{array}{lllllllllllll}\text { Max. } & 1.6 & --- & --- & 1.5 & 1.8 & 1.8 & 1.4 & 1.3 & 2.3 & 3.5 & 3.4 & 3.2\end{array}$

$\begin{array}{lllllllllllll}\text { Ave. } & 1.5 & --- & --- & 1.1 & 1.0 & 1.0 & 0.9 & 0.9 & 1.5 & 2.7 & 3.0 & 2.4\end{array}$

\begin{tabular}{lllllllllllll} 
& & & & \multicolumn{1}{c}{$\mathrm{pH}$} & & & & \\
Min. & 7.8 & 7.9 & 7.9 & 7.7 & 7.6 & 7.4 & 6.6 & 6.4 & 5.8 & 6.0 & 7.4 & 7.2 \\
Max. & 9.5 & 9.2 & 9.3 & 9.2 & 8.4 & 8.3 & 7.6 & 7.3 & 6.9 & 7.8 & 8.6 & 8.9 \\
Ave. & 8.4 & 8.4 & 8.5 & 8.2 & 8.0 & 7.9 & 7.0 & 6.7 & 6.2 & 6.8 & 7.8 & 8.1 \\
\hline
\end{tabular}


Appendix Table 26. Monthly environmental data collected from Valley Creek (rkm 609.4 from the mouth of the Salmon River) from August 2007 through July 2008.

\begin{tabular}{|c|c|c|c|c|c|c|c|c|c|c|c|c|}
\hline & Aug & Sept & Oct & Nov & Dec & Jan & Feb & Mar & Apr & May & Jun & Jul \\
\hline \multicolumn{13}{|c|}{$\underline{\text { Temperature }\left({ }^{\circ} \mathrm{C}\right)}$} \\
\hline Min. & 8.6 & 2.3 & 1.1 & 0.2 & 0.1 & 0.1 & 0.2 & 0.0 & 0.0 & 0.1 & 3.9 & 8.7 \\
\hline Max. & 22.8 & 21.4 & 12.2 & 6.6 & 3.1 & 0.7 & 1.6 & 7.1 & 11.4 & 13.7 & 18.3 & 20.8 \\
\hline Ave. & 15.0 & 10.5 & 5.6 & 1.8 & 0.5 & 0.3 & 0.5 & 2.0 & 3.6 & 6.3 & 10.0 & 14.4 \\
\hline \multicolumn{13}{|c|}{ Dissolved oxygen (ppm) } \\
\hline Min. & 6.0 & 9.0 & 13.2 & 10.4 & 11.3 & 11.0 & 11.5 & 11.0 & 8.9 & 8.3 & 7.9 & 7.6 \\
\hline Max. & 14.5 & 14.8 & 14.9 & 14.8 & 12.9 & 13.9 & 14.8 & 14.9 & 14.9 & 11.6 & 11.2 & 10.5 \\
\hline Ave. & 11.8 & 13.3 & 14.2 & 12.5 & 12.0 & 12.0 & 12.7 & 12.9 & 11.1 & 10.0 & 9.5 & 8.9 \\
\hline \multicolumn{13}{|c|}{$\underline{\text { Specific conductance }(\mu \mathrm{S} / \mathrm{cm})}$} \\
\hline Min. & 69.0 & 66.0 & 48.0 & 42.0 & 53.0 & 58.0 & 60.0 & 60.0 & 51.0 & 32.0 & 33.0 & 33.0 \\
\hline Max. & 81.0 & 79.0 & 73.0 & 74.0 & 68.0 & 64.0 & 70.0 & 78.0 & 78.0 & 58.0 & 40.0 & 50.0 \\
\hline Ave. & 72.7 & 72.5 & 65.7 & 59.7 & 59.7 & 60.8 & 62.9 & 65.9 & 65.1 & 39.8 & 36.0 & 41.5 \\
\hline \multicolumn{13}{|c|}{ Turbidity (ntu) } \\
\hline Min. & 0.2 & 0.3 & 0.1 & 0.0 & 0.0 & 0.0 & 0.2 & 0.3 & 0.0 & 1.2 & 1.2 & 2.0 \\
\hline Max. & 413.1 & 254.0 & 52.8 & 13.2 & 4.3 & 2.2 & 31.9 & 232.6 & 36.9 & 59.3 & 30.9 & 305 \\
\hline Ave. & 1.6 & 1.7 & 2.3 & 1.4 & 0.4 & 0.7 & 1.0 & 1.7 & 2.6 & 8.0 & 5.9 & 15.4 \\
\hline \multicolumn{13}{|c|}{ Depth (ft) } \\
\hline Min. & 1.1 & 0.9 & 0.9 & 0.5 & 0.4 & 0.0 & 0.3 & 0.3 & 0.5 & 2.0 & 2.6 & 1.9 \\
\hline Max. & 1.5 & 1.6 & 2.4 & 1.9 & 1.5 & 1.5 & 1.3 & 1.3 & 2.3 & 3.8 & 3.4 & 3.3 \\
\hline Ave. & 1.3 & 1.3 & 1.5 & 1.4 & 0.9 & 0.9 & 0.8 & 0.8 & 1.5 & 3.0 & 3.1 & 2.4 \\
\hline \multicolumn{13}{|c|}{$\underline{\mathrm{pH}}$} \\
\hline Min. & 7.5 & 7.4 & 6.9 & 7.3 & 7.4 & 7.2 & 7.2 & 7.6 & 7.3 & 6.8 & 6.8 & 6.8 \\
\hline Max. & 8.6 & 8.7 & 8.7 & 8.9 & 8.1 & 8.0 & 8.4 & 8.6 & 8.7 & 8.2 & 8.4 & 8.2 \\
\hline Ave. & 8.0 & 7.9 & 7.7 & 7.7 & 7.7 & 7.4 & 7.6 & 7.9 & 7.8 & 7.3 & 7.4 & 7.5 \\
\hline
\end{tabular}


Appendix Table 27. Monthly environmental data collected from South Fork Salmon River (rkm 112 from the mouth of the South Fork Salmon River) from August 2007 through July 2008.

\begin{tabular}{lcccccccccccc}
\hline & Aug & Sept & Oct & Nov & Dec & Jan & Feb & Mar & Apr & May & Jun & Jul \\
\hline \multicolumn{1}{c}{} & & \multicolumn{1}{c}{ Temperature $\left({ }^{\circ} \mathrm{C}\right)$} \\
Min. & 9.5 & 3.7 & 1.3 & -0.2 & -0.2 & -0.2 & -0.2 & -0.2 & -0.2 & 0.4 & 2.3 & 8.3 \\
Max. & 20.6 & 19.3 & 9.9 & 4.2 & 1.2 & 0.3 & 3.2 & 5.3 & 8.0 & 9.5 & 15.7 & 18.2 \\
Ave. & 13.9 & 10.3 & 5.1 & 1.2 & -0.1 & -0.1 & 0.3 & 1.3 & 2.3 & 4.6 & 7.6 & 13.8
\end{tabular}

Dissolved oxygen (ppm)

$\begin{array}{lcccccccccccc}\text { Min. } & 8.1 & 8.6 & 11.5 & --- & --- & --- & --- & --- & 9.8 & 9.9 & 9.2 & 8.5 \\ \text { Max. } & 11.6 & 14.1 & 14.8 & --- & --- & --- & --- & --- & 12.7 & 12.6 & 13.0 & 11.7 \\ \text { Ave. } & 9.8 & 11.3 & 12.8 & --- & --- & --- & --- & --- & 11.3 & 11.4 & 11.2 & 9.9\end{array}$

Specific conductance $(\mu \mathrm{S} / \mathrm{cm})$

$\begin{array}{lllllllllllll}\text { Min. } & 39.0 & 43.0 & 43.0 & 31.0 & 40.0 & 41.0 & 44.0 & 44.0 & 47.0 & 30.0 & 28.0 & 36.0\end{array}$

$\begin{array}{lllllllllllll}\text { Max. } & 78.0 & 67.0 & 73.0 & 66.0 & 57.0 & 60.0 & 60.0 & 64.0 & 69.0 & 54.0 & 38.0 & 132.0\end{array}$

$\begin{array}{lllllllllllll}\text { Ave. } & 48.0 & 48.3 & 53.9 & 52.0 & 51.7 & 54.2 & 56.7 & 57.1 & 58.5 & 42.1 & 31.4 & 49.1\end{array}$

Turbidity (ntu)

$\begin{array}{lllllllllllll}\text { Min. } & 0.0 & 0.0 & --- & --- & --- & --- & --- & --- & --- & --- & --- & --\end{array}$

$\begin{array}{lllllllllllll}\text { Max. } & 483 & 542 & -- & --- & --- & --- & -- & -- & --- & --- & --- & --\end{array}$

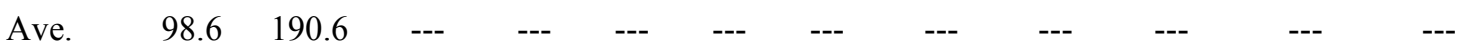

Depth (ft)

$\begin{array}{lllllllllllll}\text { Min. } & 1.2 & 1.0 & 1.1 & 1.5 & 1.2 & 1.6 & 1.2 & 1.2 & 1.0 & 1.7 & 1.9 & 1.2\end{array}$

$\begin{array}{lllllllllllll}\text { Max. } & 1.8 & 1.8 & 3.2 & 2.4 & 3.9 & 4.0 & 2.9 & 2.2 & 2.0 & 4.5 & 3.5 & 2.0\end{array}$

$\begin{array}{lllllllllllll}\text { Ave. } & 1.4 & 1.5 & 1.7 & 1.9 & 2.4 & 2.8 & 1.8 & 1.6 & 1.5 & 2.8 & 2.5 & 1.5\end{array}$

\begin{tabular}{lllllllllllll} 
& & \multicolumn{10}{c}{$\mathrm{pH}$} & \\
Min. & 7.1 & 7.0 & 7.0 & 7.1 & 7.3 & 7.4 & 7.5 & 7.5 & 6.9 & 6.8 & 6.8 & 6.8 \\
Max. & 9.2 & 8.9 & 8.6 & 7.9 & 8.1 & 7.8 & 8.2 & 9.0 & 8.3 & 8.2 & 8.0 & 8.0 \\
Ave. & 7.8 & 7.6 & 7.5 & 7.4 & 7.5 & 7.5 & 7.6 & 7.8 & 7.4 & 7.1 & 7.1 & 7.3 \\
\hline
\end{tabular}


Appendix Table 28. Monthly environmental data collected from Secesh River (rkm 27 upstream from its confluence with the South Fork Salmon River) from August 2007 through July 2008.

\begin{tabular}{lcccccccccccc}
\hline & Aug & Sept & Oct & Nov & Dec & Jan & Feb & Mar & Apr & May & Jun & Jul \\
\hline & & \multicolumn{1}{c}{ Temperature $\left({ }^{\circ} \mathrm{C}\right)$} \\
Min. & 7.9 & 2.0 & 0.0 & 0.0 & 0.1 & 0.1 & --- & -- & --- & --- & --- & --- \\
Max. & 20.7 & 17.0 & 7.0 & 2.2 & 0.1 & 0.1 & --- & --- & --- & --- & --- & --- \\
Ave. & 13.1 & 8.9 & 2.9 & 0.2 & 0.1 & 0.1 & --- & --- & --- & --- & --- & --
\end{tabular}

Dissolved oxygen (ppm)

$\begin{array}{lllllllllllll}\text { Min. } & --- & --- & 9.5 & 6.9 & --- & --- & --- & -- & --- & --- & --- & --- \\ \text { Max. } & --- & --- & 14.2 & 11.5 & --- & --- & --- & -- & --- & --- & --- & --- \\ \text { Ave. } & --- & --- & 10.2 & 8.7 & --- & --- & --- & --- & --- & --- & --- & ---\end{array}$

Specific conductance $(\mu \mathrm{S} / \mathrm{cm})$

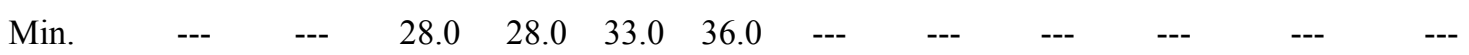

$\begin{array}{lllllllllllll}\text { Max. } & --- & --- & 37.0 & 37.0 & 37.0 & 38.0 & --- & --- & -- & --- & --- & \text {--- }\end{array}$

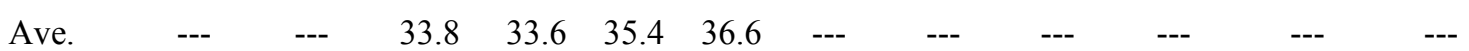

Turbidity (ntu)

$\begin{array}{lllcccccccccc}\text { Min. } & --- & --- & 0.0 & 0.0 & --- & --- & -- & -- & --- & --- & --- & --- \\ \text { Max. } & --- & --- & 392.8 & 400 & --- & --- & --- & --- & --- & --- & --- & --- \\ \text { Ave. } & --- & --- & 28.6 & 21.0 & --- & --- & --- & --- & --- & --- & --- & ---\end{array}$

Depth (ft)

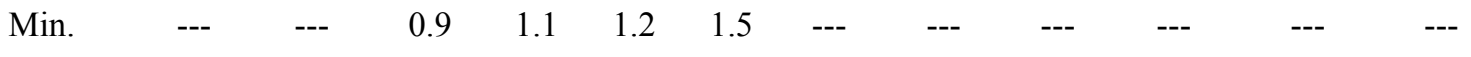

$\begin{array}{lllllllllllll}\text { Max. } & --- & --- & 2.1 & 2.2 & 2.8 & 3.1 & -- & --- & -- & --- & --- & --\end{array}$

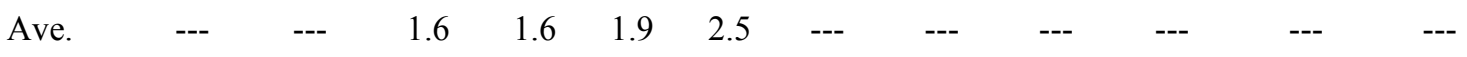

\begin{tabular}{|c|c|c|c|c|c|c|c|c|c|c|c|c|}
\hline \multicolumn{13}{|c|}{$\underline{\mathrm{pH}}$} \\
\hline Min. & 7.3 & 7.5 & 7.0 & 7.0 & 6.9 & 6.9 & --- & --- & --- & --- & --- & --- \\
\hline Max. & 9.7 & 9.3 & 8.8 & 7.7 & 7.1 & 7.0 & --- & --- & --- & --- & --- & --- \\
\hline Ave. & 8.1 & 8.1 & 7.4 & 7.2 & 7.0 & 7.0 & --- & --- & --- & --- & --- & --- \\
\hline
\end{tabular}


Appendix Table 29. Monthly environmental data collected from Big Creek near Taylor Ranch (rkm 10 from its confluence with the Middle Fork Salmon River) from August 2007 through July 2008.

\begin{tabular}{|c|c|c|c|c|c|c|c|c|c|c|c|c|}
\hline & Aug & Sept & Oct & Nov & Dec & Jan & Feb & Mar & Apr & May & Jun & Jul \\
\hline \multicolumn{13}{|c|}{$\underline{\text { Temperature }\left({ }^{\circ} \mathrm{C}\right)}$} \\
\hline Min. & 10.4 & 5.4 & 1.3 & 0.0 & 0.0 & 0.0 & 0.0 & 0.0 & 0.0 & 4,5 & 4.3 & 8.9 \\
\hline Max. & 20.4 & 19.2 & 10.6 & 5.3 & 2.1 & 0.5 & 1.6 & 7.4 & 9.3 & 9.2 & 13.2 & 18.3 \\
\hline Ave. & 14.7 & 11.1 & 6.3 & 1.4 & 0.2 & 0.0 & 0.2 & 2.0 & 3.5 & 6.6 & 8.3 & 13.3 \\
\hline \multicolumn{13}{|c|}{ Dissolved oxygen (ppm) } \\
\hline Min. & 8.2 & 8.0 & 10.1 & --- & --- & --- & --- & --- & --- & 11.7 & 10.0 & 4.1 \\
\hline Max. & 14.4 & 12.8 & 14.2 & --- & --- & --- & --- & --- & --- & 13.3 & 13.5 & 10.9 \\
\hline Ave. & 10.4 & 10.2 & 11.3 & --- & --- & --- & --- & --- & --- & 12.7 & 11.9 & 7.7 \\
\hline \multicolumn{13}{|c|}{$\underline{\text { Specific conductance }(\mu \mathrm{S} / \mathrm{cm})}$} \\
\hline Min. & 81.0 & 91.0 & 78.0 & 83.0 & 97.0 & 108.0 & 109.0 & 112.0 & 123.0 & 50.0 & 49.0 & 54.0 \\
\hline Max. & 103.0 & 160.0 & 160.0 & 113.0 & 128.0 & 126.0 & 122.0 & 133.0 & 134.0 & 61.0 & 65.0 & 150.0 \\
\hline Ave. & 91.7 & 108.0 & 103.3 & 100.7 & 111.8 & 113.9 & 113.7 & 122.0 & 130.1 & 56.8 & 56.3 & 87.4 \\
\hline \multicolumn{13}{|c|}{ Turbidity (ntu) } \\
\hline Min. & 0.0 & 0.0 & 0.6 & 0.0 & 0.0 & 0.0 & 0.0 & 0.0 & 0.4 & 35.8 & 8.3 & --- \\
\hline Max. & 276.0 & 218.8 & 469.4 & 531.5 & 103.9 & 17.9 & 440.0 & 537.2 & 530.3 & 539.9 & 307.6 & --- \\
\hline Ave. & 2.4 & 2.0 & 47.9 & 11.5 & 0.6 & 0.0 & 7.2 & 81.5 & 151.4 & 143.2 & 35.2 & --- \\
\hline \multicolumn{13}{|c|}{ Depth (ft) } \\
\hline Min. & 0.4 & 0.4 & 0.5 & 1.0 & 0.8 & 0.6 & 0.9 & 0.6 & 0.8 & 3.4 & 2.9 & 1.7 \\
\hline Max. & 1.2 & 1.4 & 2.0 & 2.2 & 2.0 & 3.0 & 1.9 & 1.7 & 1.6 & 6.1 & 4.4 & 3.5 \\
\hline Ave. & 0.8 & 0.8 & 1.3 & 1.5 & 1.3 & 1.8 & 1.4 & 1.3 & 1.1 & 4.2 & 3.7 & 2.3 \\
\hline \multicolumn{13}{|c|}{$\mathrm{pH}$} \\
\hline Min. & 7.3 & 7.2 & 6.8 & 7.9 & 7.9 & 7.9 & 7.9 & 7.8 & 7.8 & 7.4 & 7.2 & 7.2 \\
\hline Max. & 9.3 & 9.2 & 8.7 & 8.9 & 8.9 & 8.6 & 9.0 & 9.5 & 9.5 & 7.6 & 8.0 & 8.4 \\
\hline Ave. & 8.1 & 8.0 & 7.6 & 8.1 & 8.2 & 8.1 & 8.1 & 8.4 & 8.6 & 7.5 & 7.5 & 7.7 \\
\hline
\end{tabular}



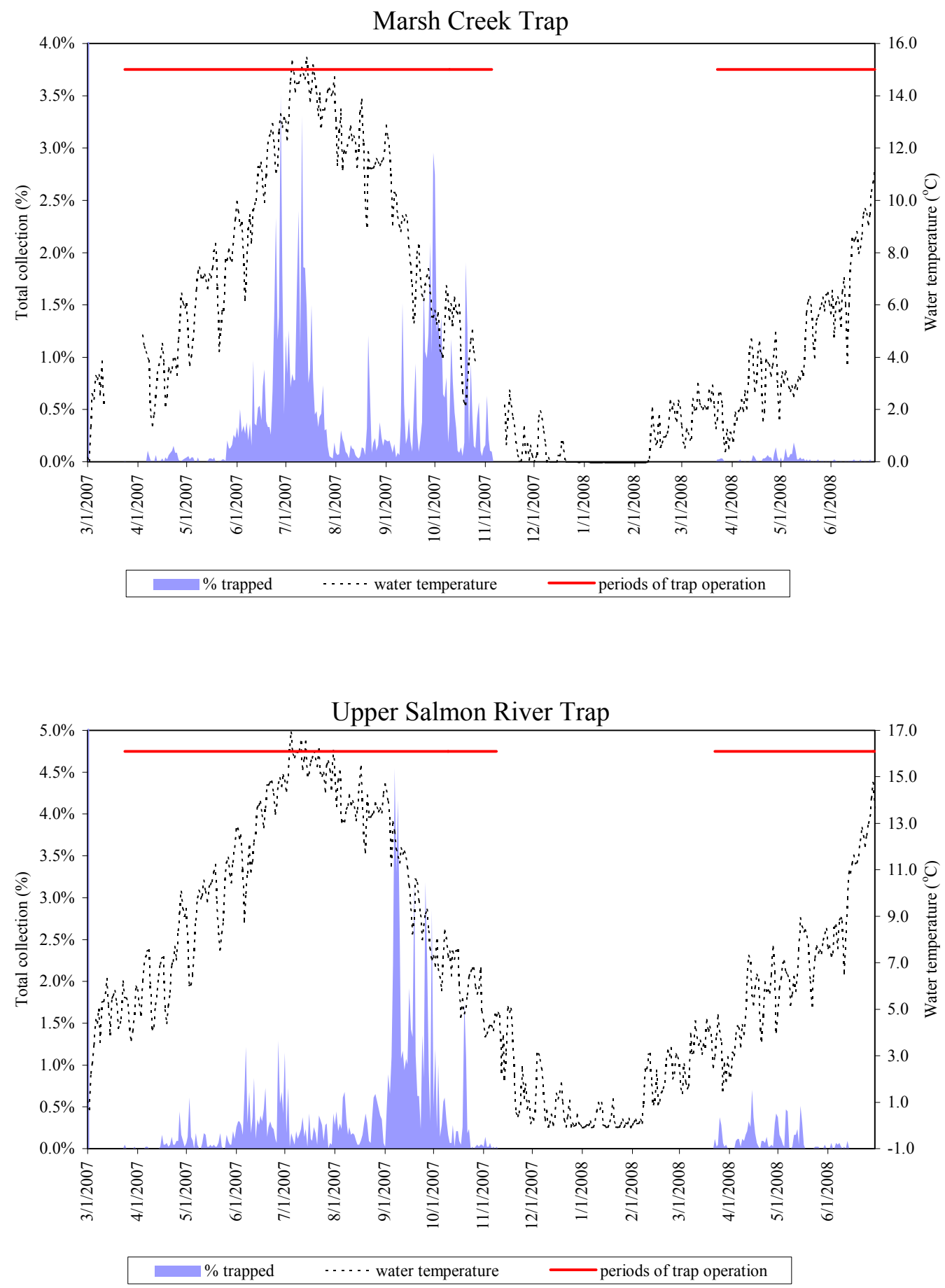

Appendix Figure 1. Daily passage of wild Chinook salmon fry, parr, and smolts at four migrant traps, expressed as percentages of total collected, and plotted against average daily water temperatures collected near traps. Periods of trap operation are also shown. 


\section{South Fork Salmon River Trap}

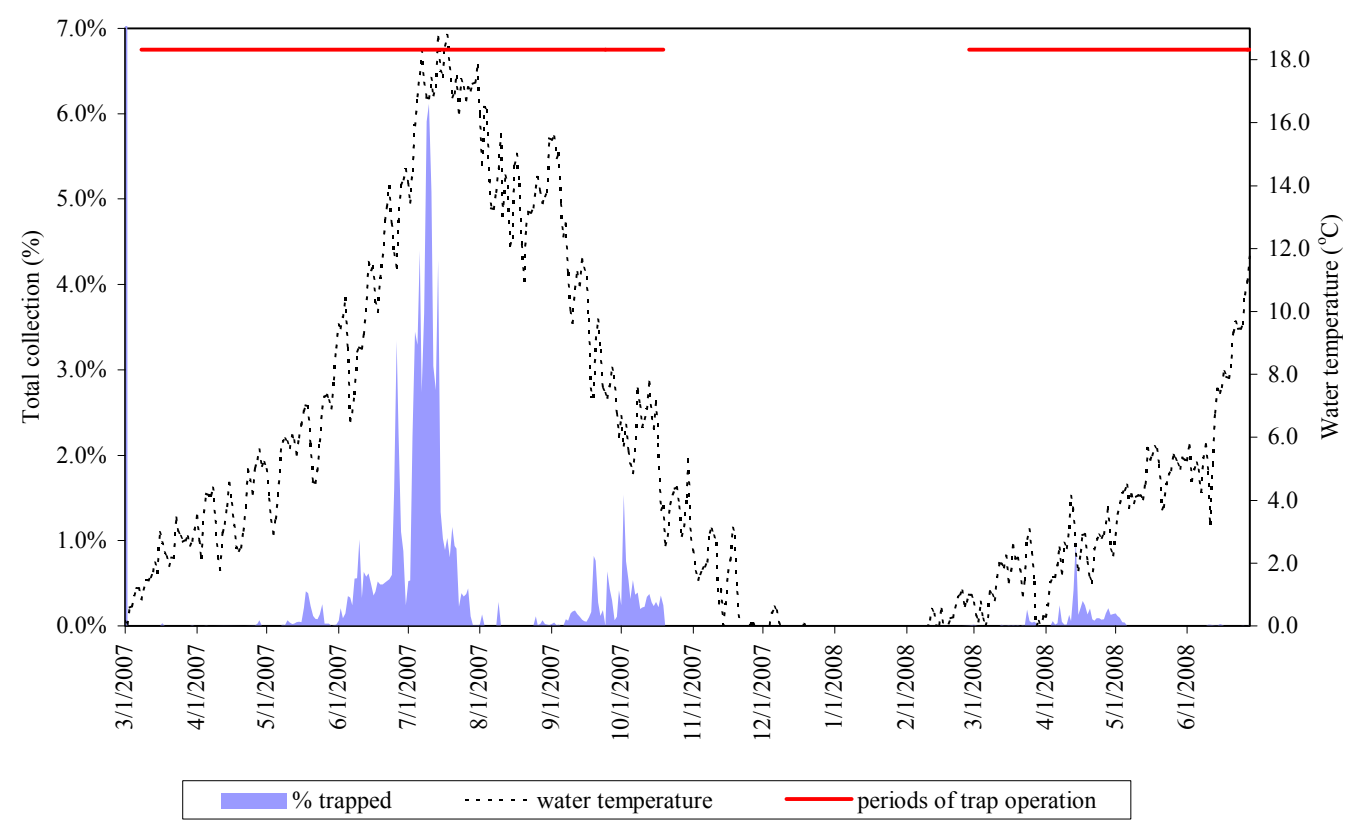

Secesh River Trap

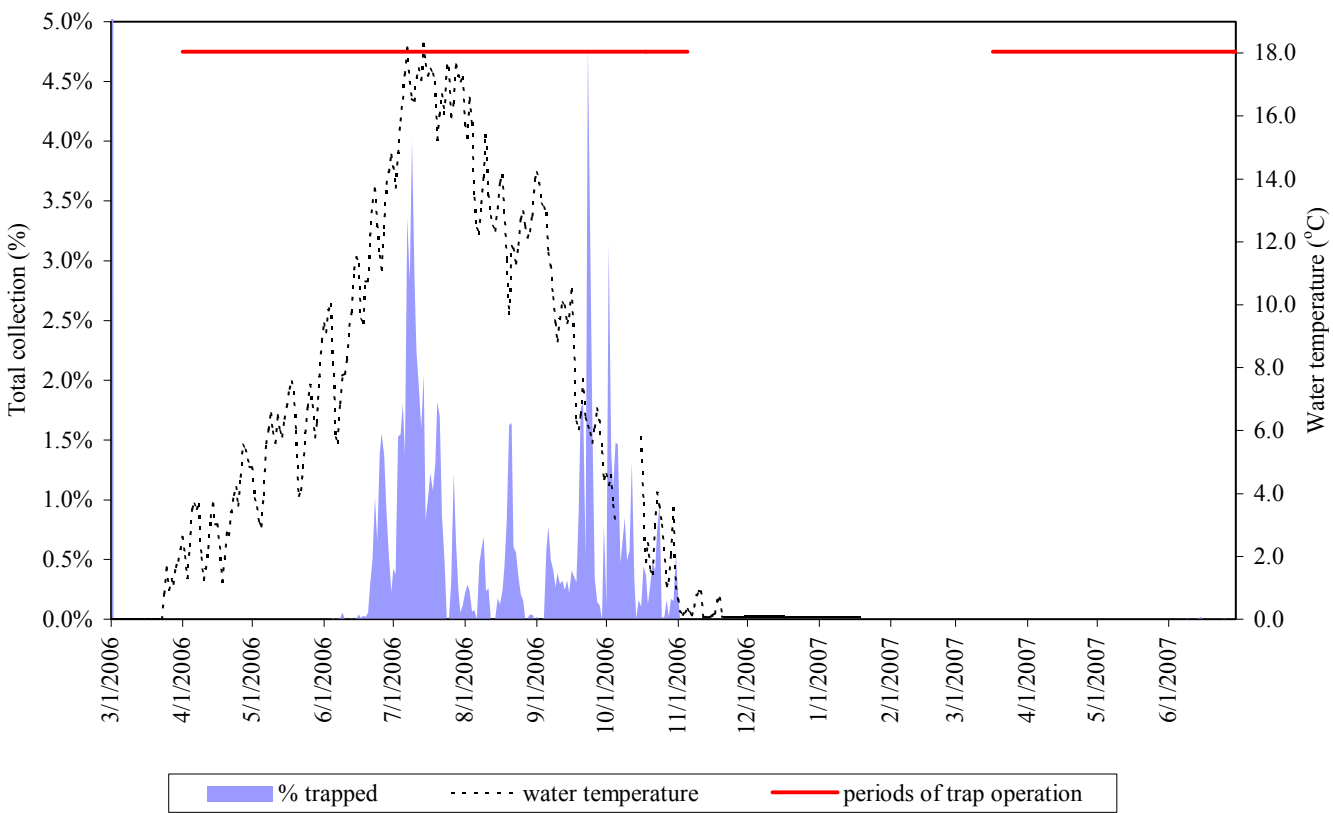

\section{Appendix Figure 1. Continued.}




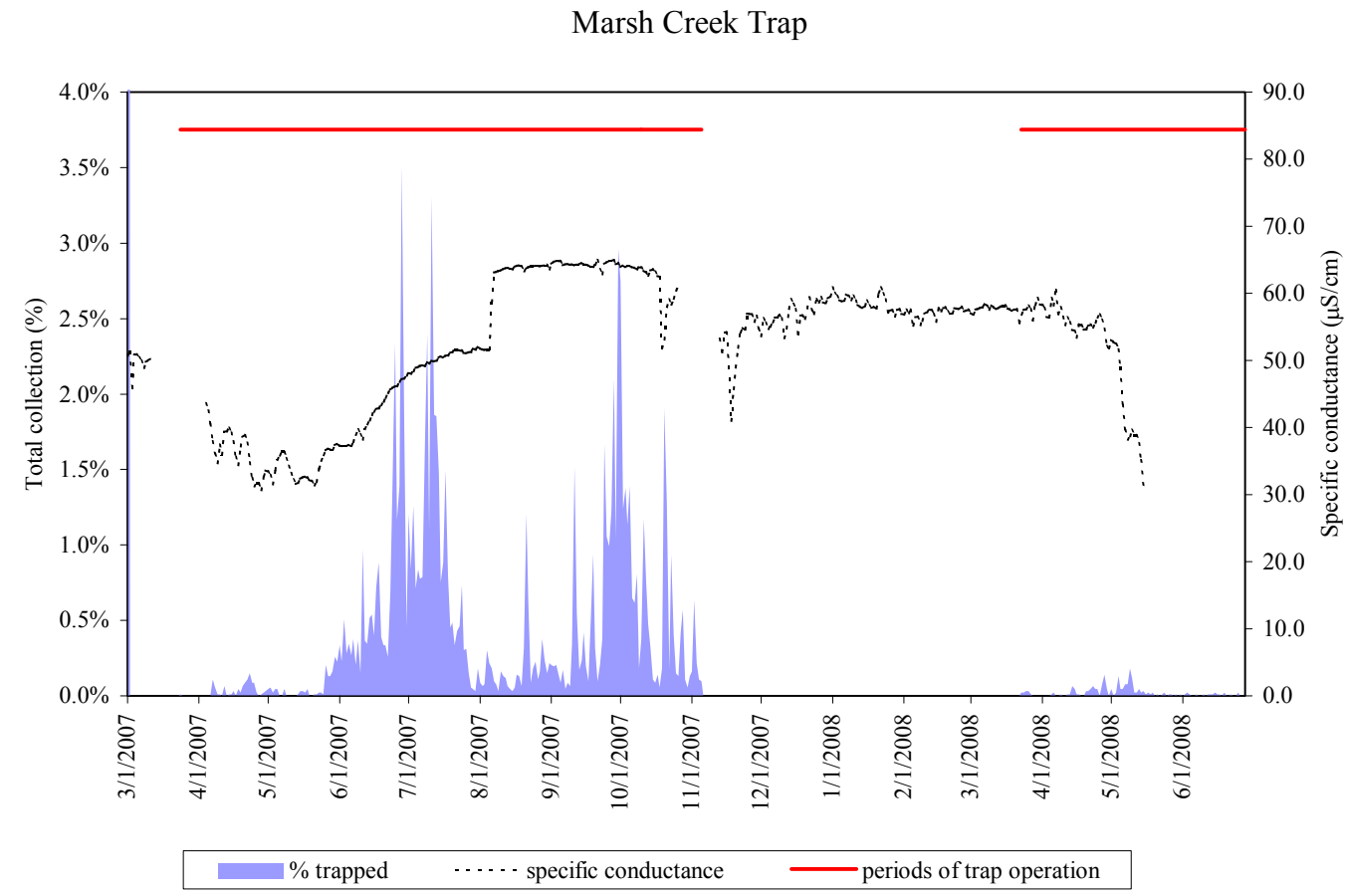

Upper Salmon River Trap

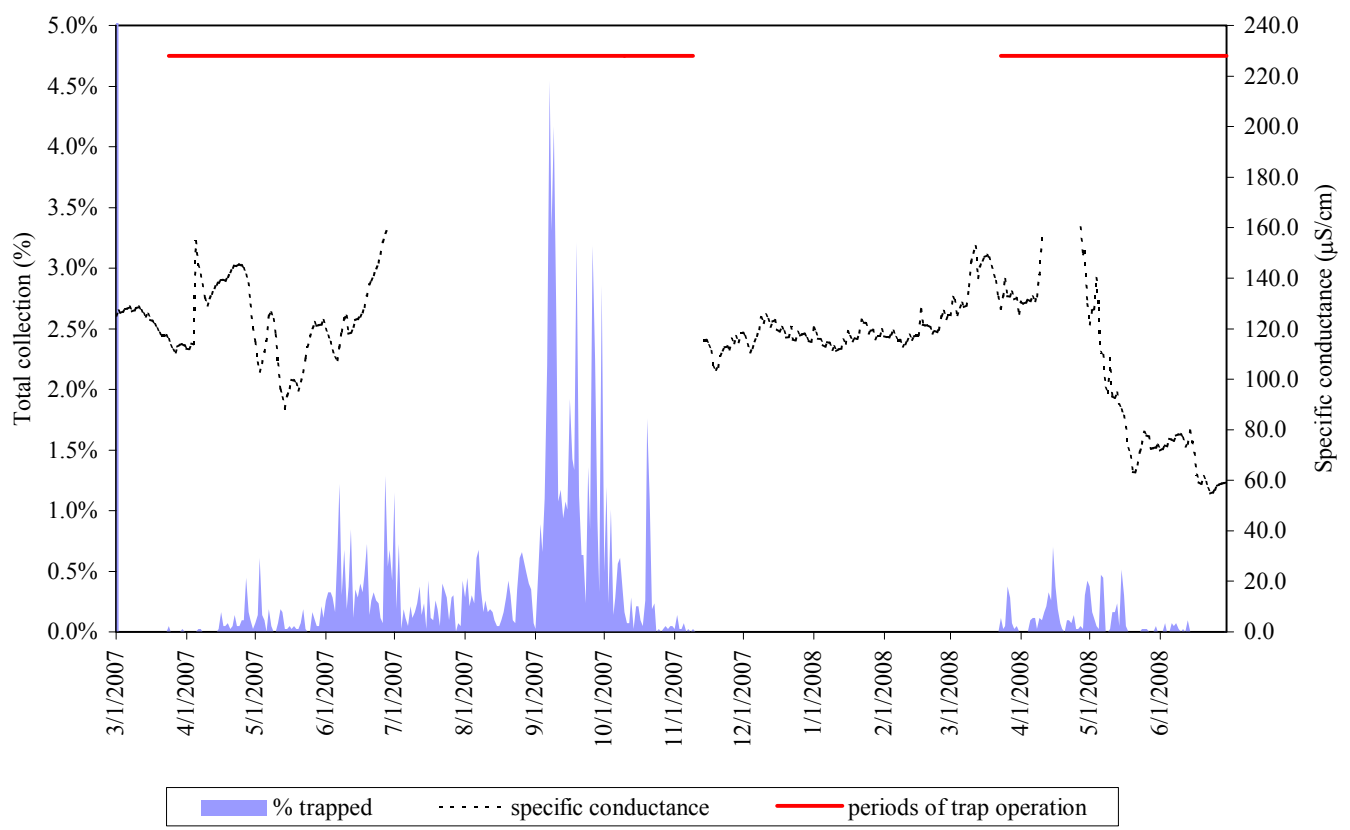

Appendix Figure 2. Daily passage of wild Chinook salmon fry, parr, and smolts at four migrant traps, expressed as percentages of total collected, and plotted against average daily specific conductance collected near traps. Periods of trap operation are also shown. 
South Fork Salmon River Trap

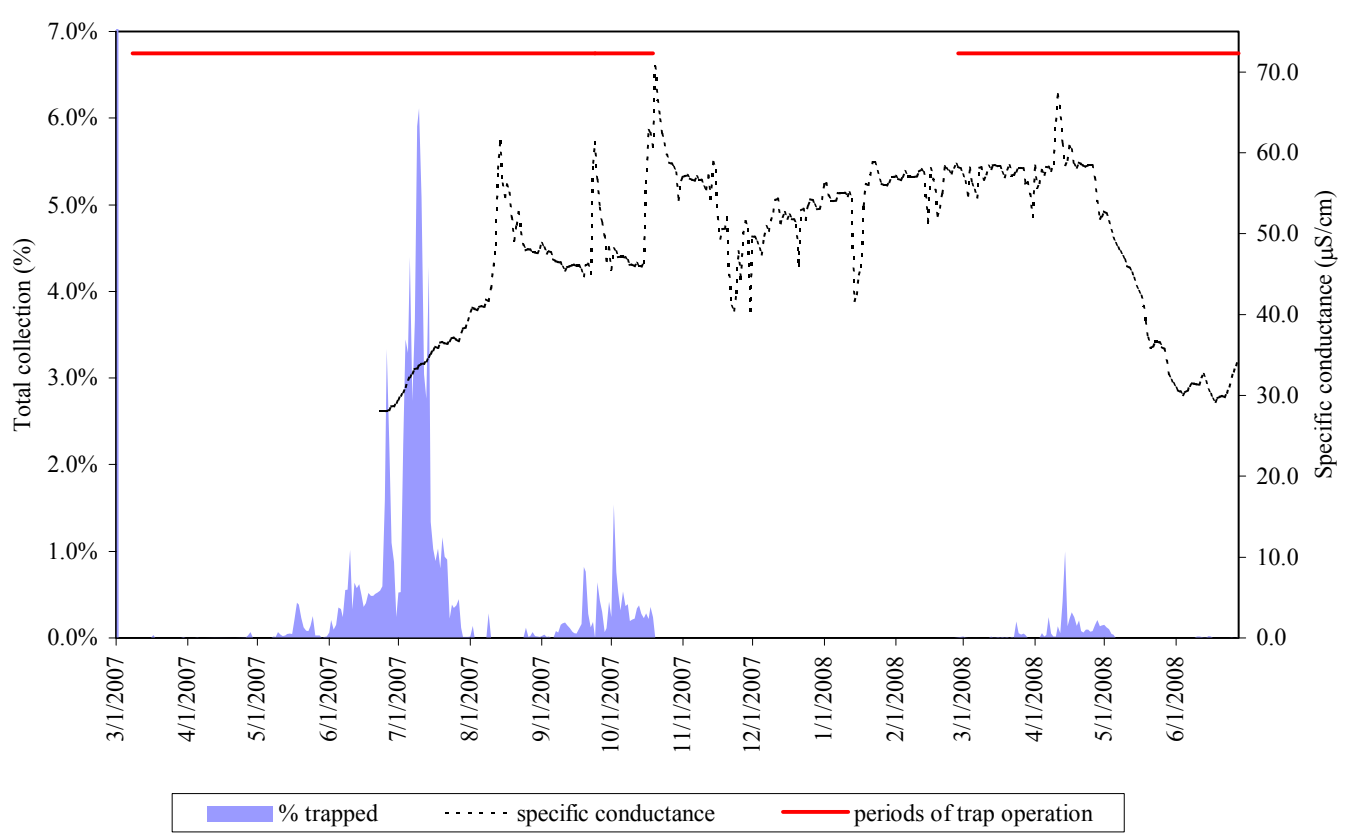

Secesh River Trap

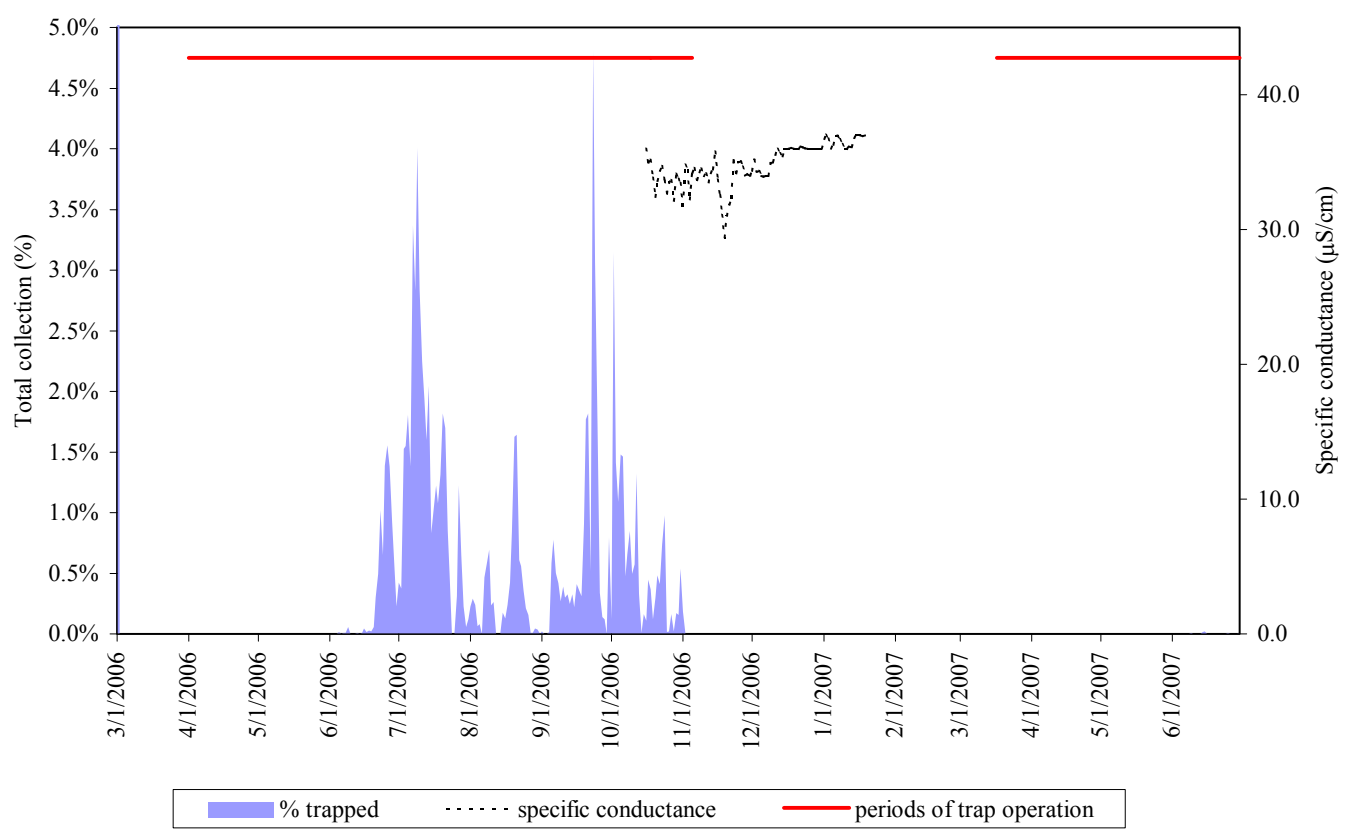

Appendix Figure 2. Continued. 
Marsh Creek Trap

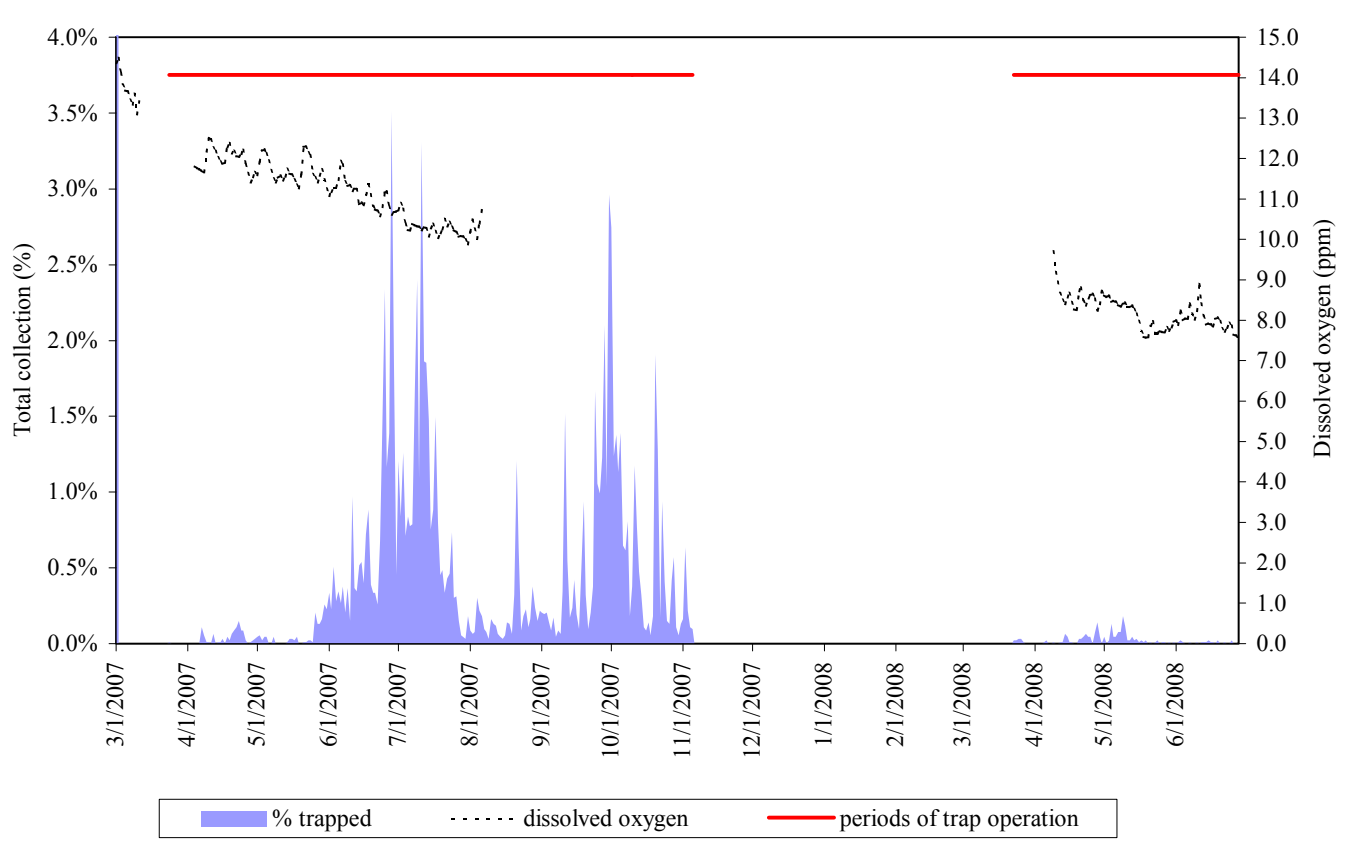

Upper Salmon River Trap

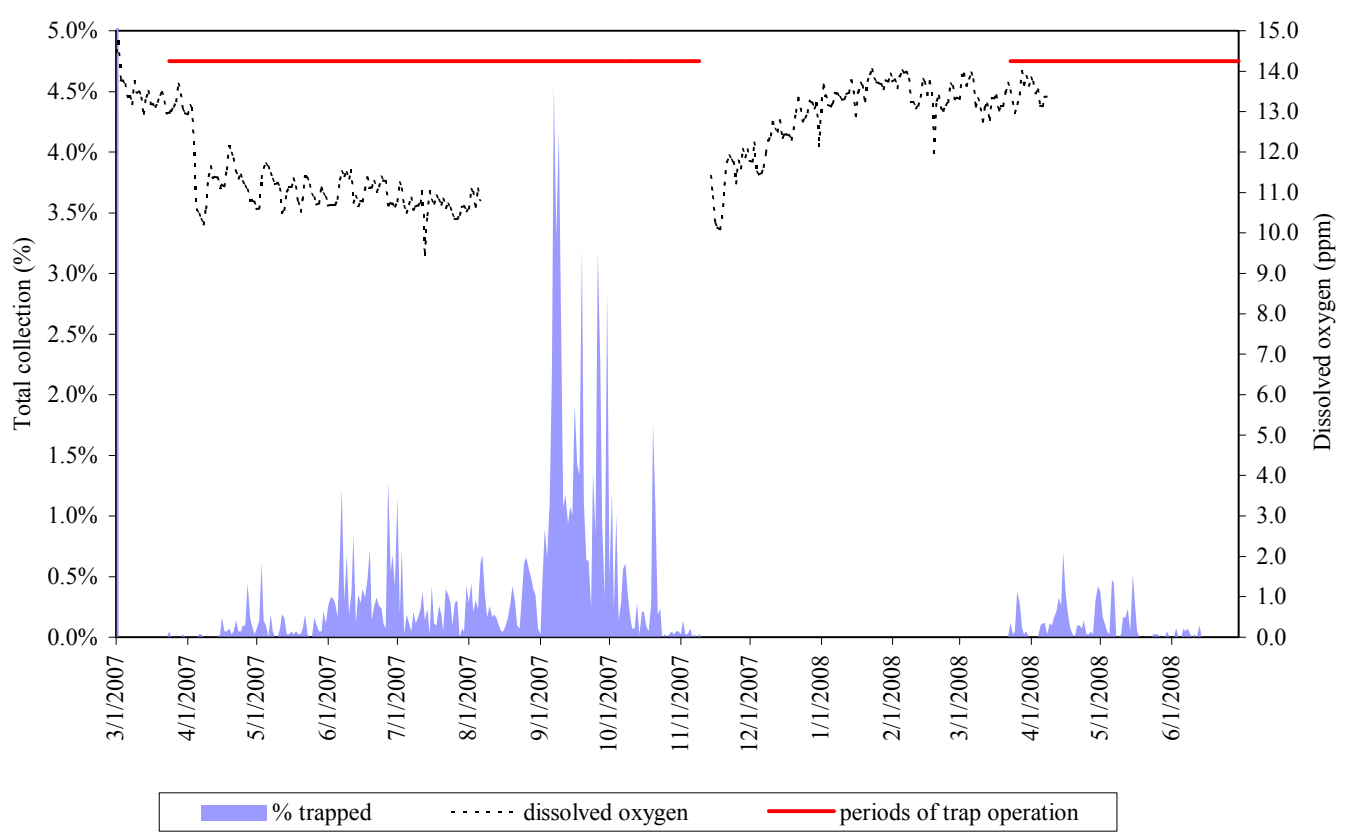

Appendix Figure 3. Daily passage of wild Chinook salmon fry, parr, and smolts at four migrant traps, expressed as percentages of total collected, and plotted against average daily dissolved oxygen collected near traps. Periods of trap operation are also shown. 
South Fork Salmon River Trap

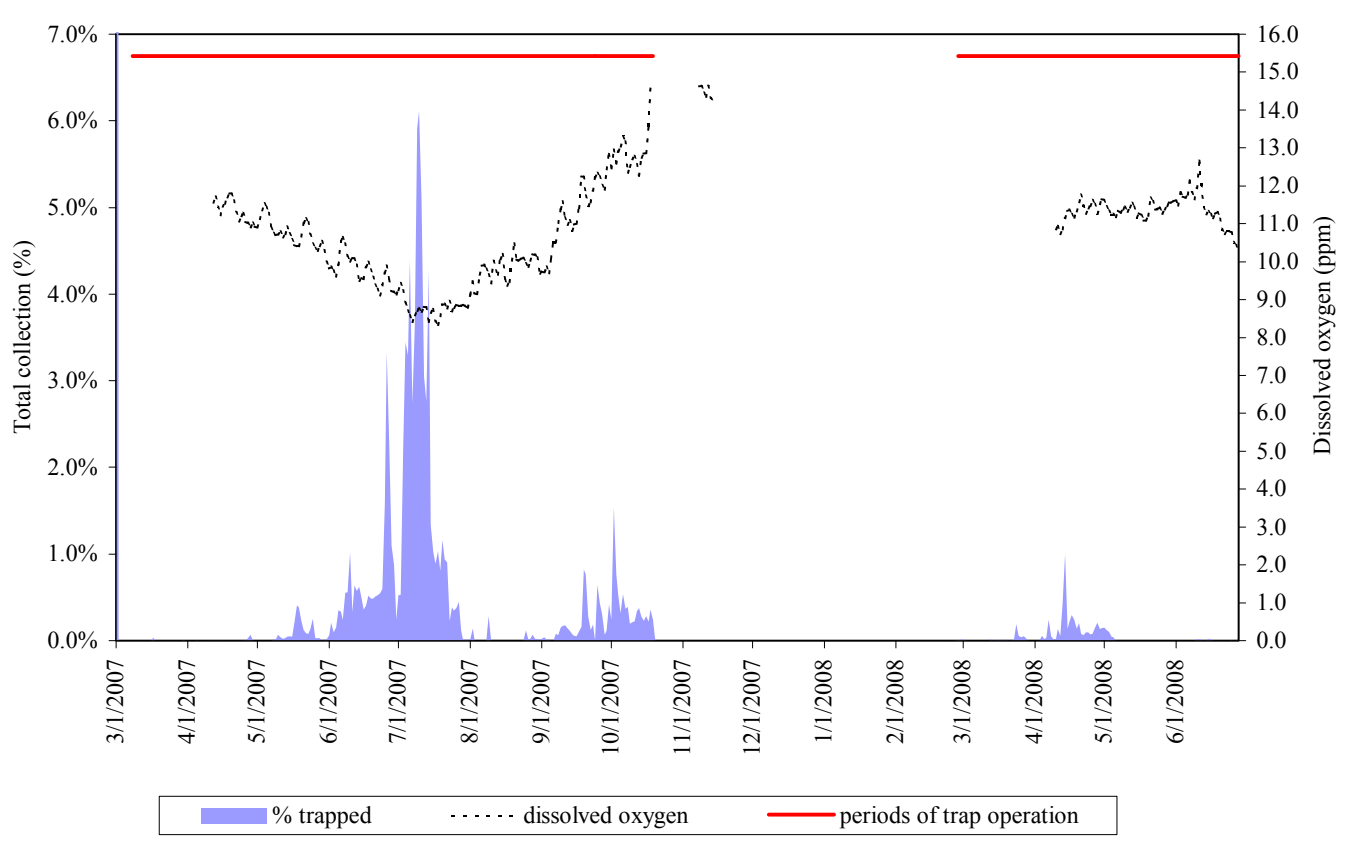

Secesh River Trap

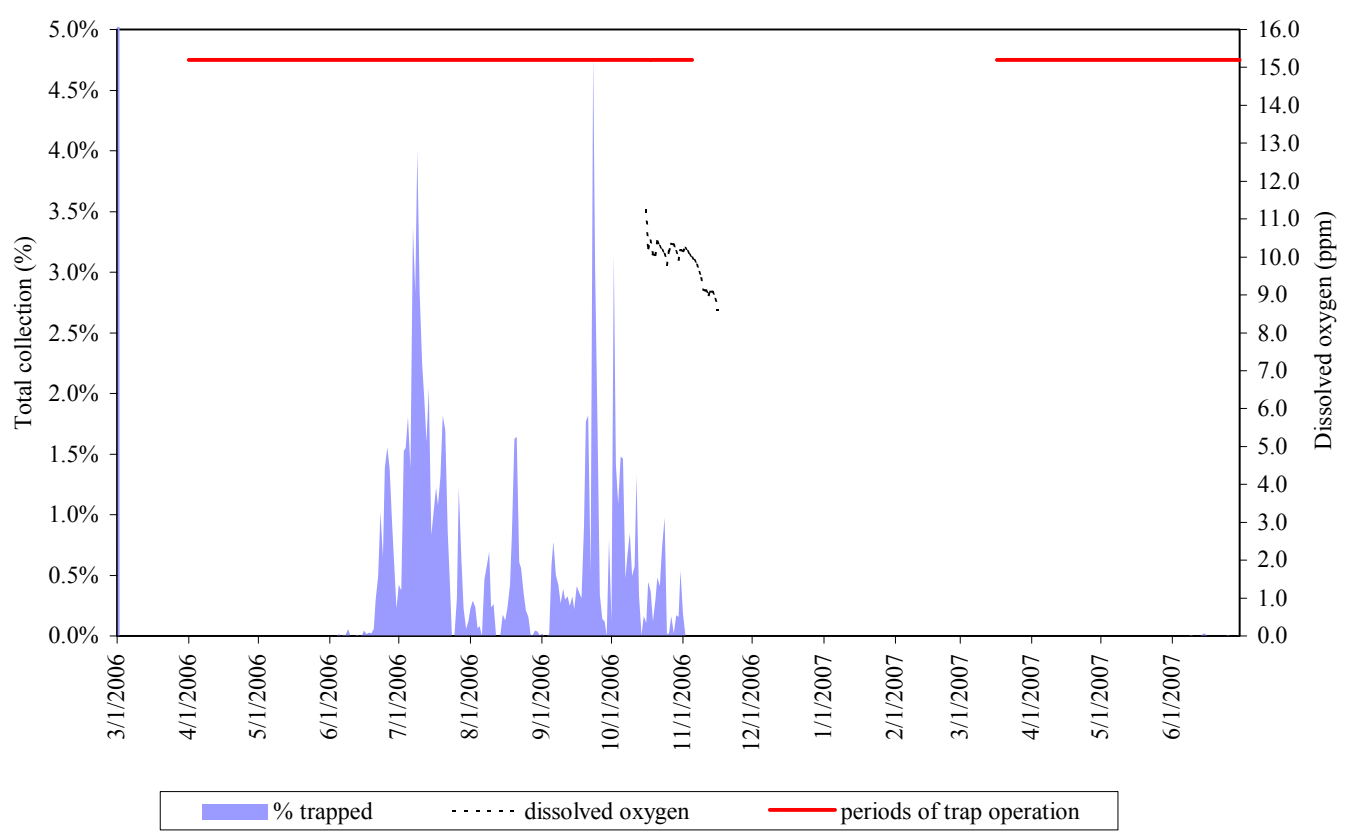

Appendix Figure 3. Continued. 

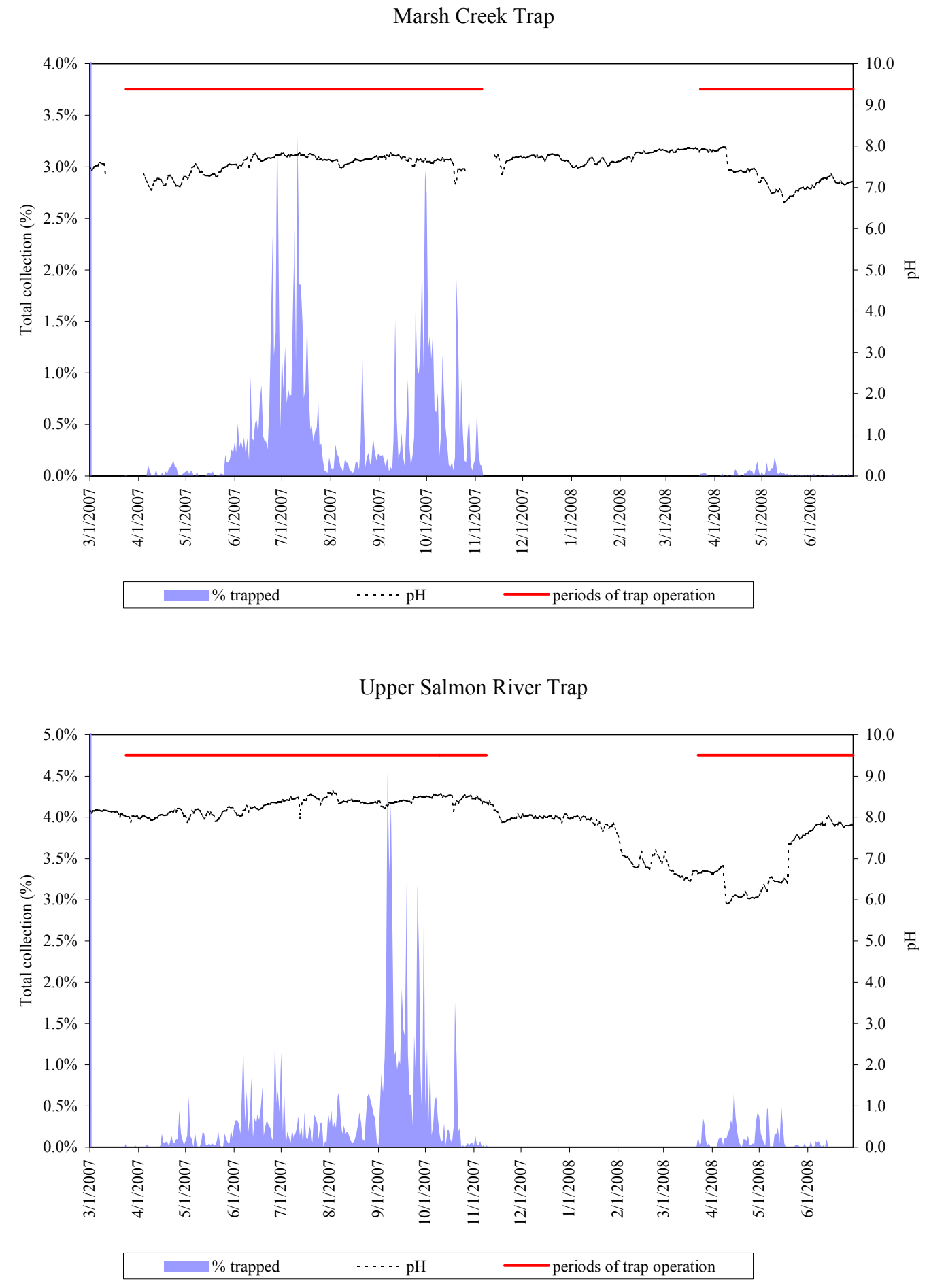

Appendix Figure 4. Daily passage of wild Chinook salmon fry, parr, and smolts at four migrant traps, expressed as percentages of total collected, and plotted against average daily $\mathrm{pH}$ collected near traps. Periods of trap operation are also shown. 
South Fork Salmon River Trap

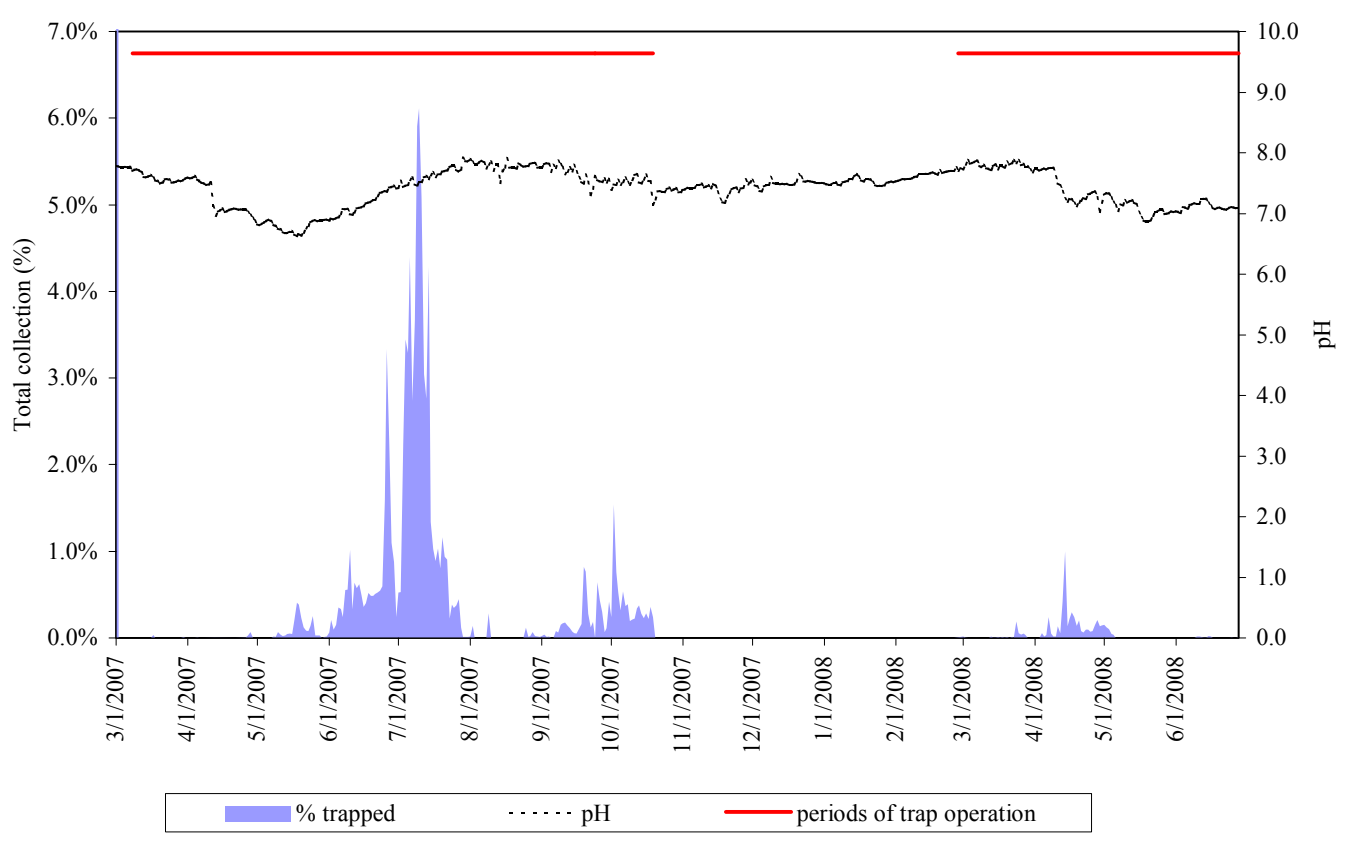

Secesh River Trap

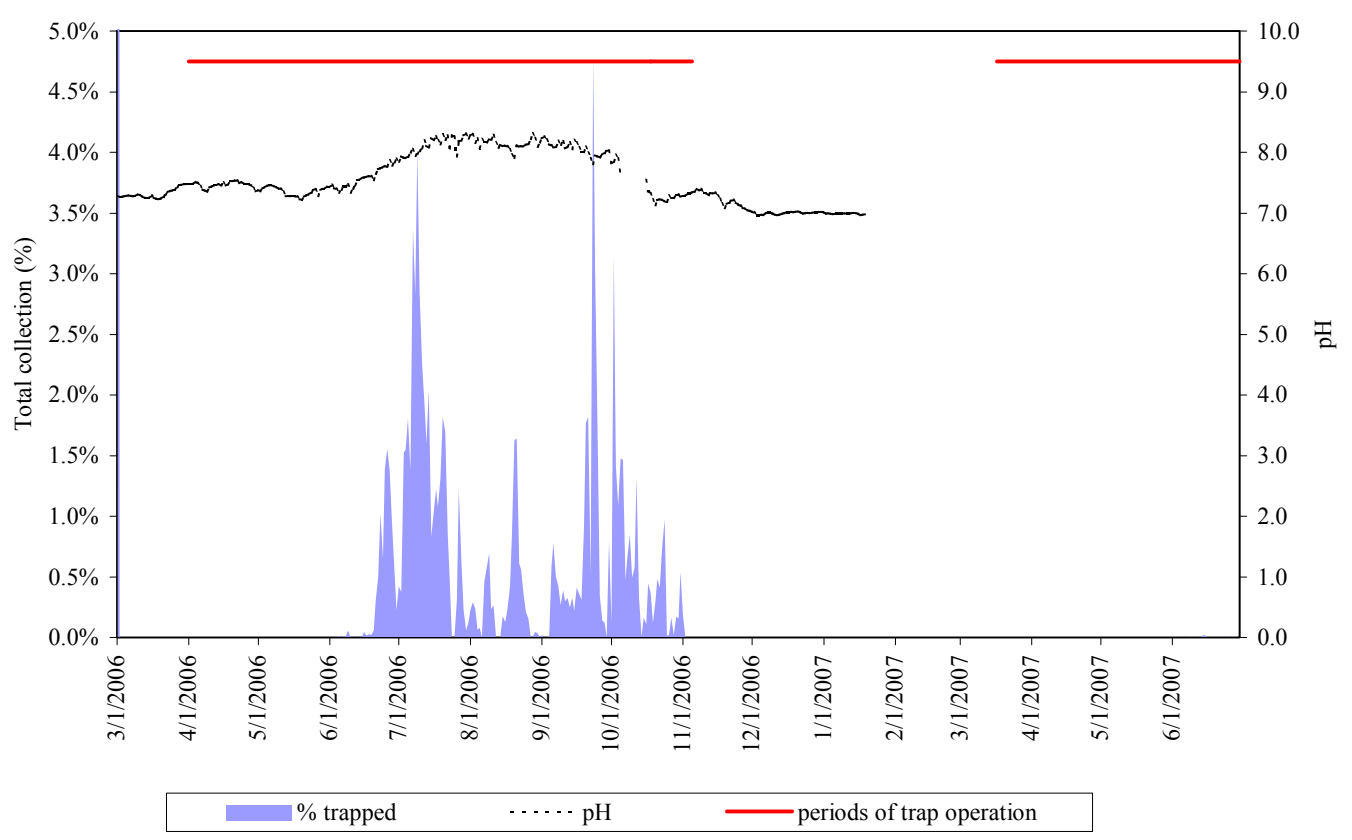

Appendix Figure 4. Continued. 


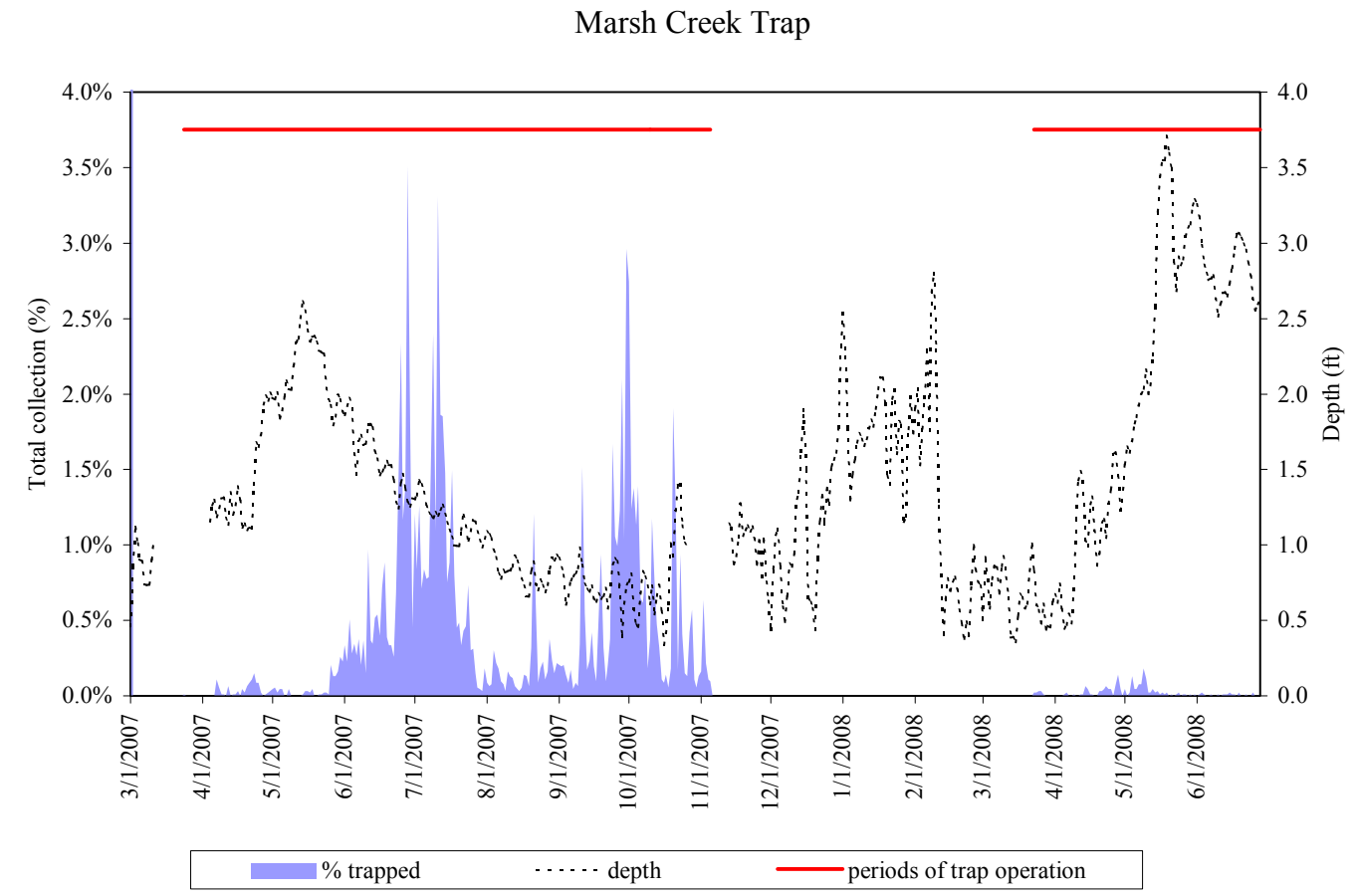

\section{Upper Salmon River Trap}

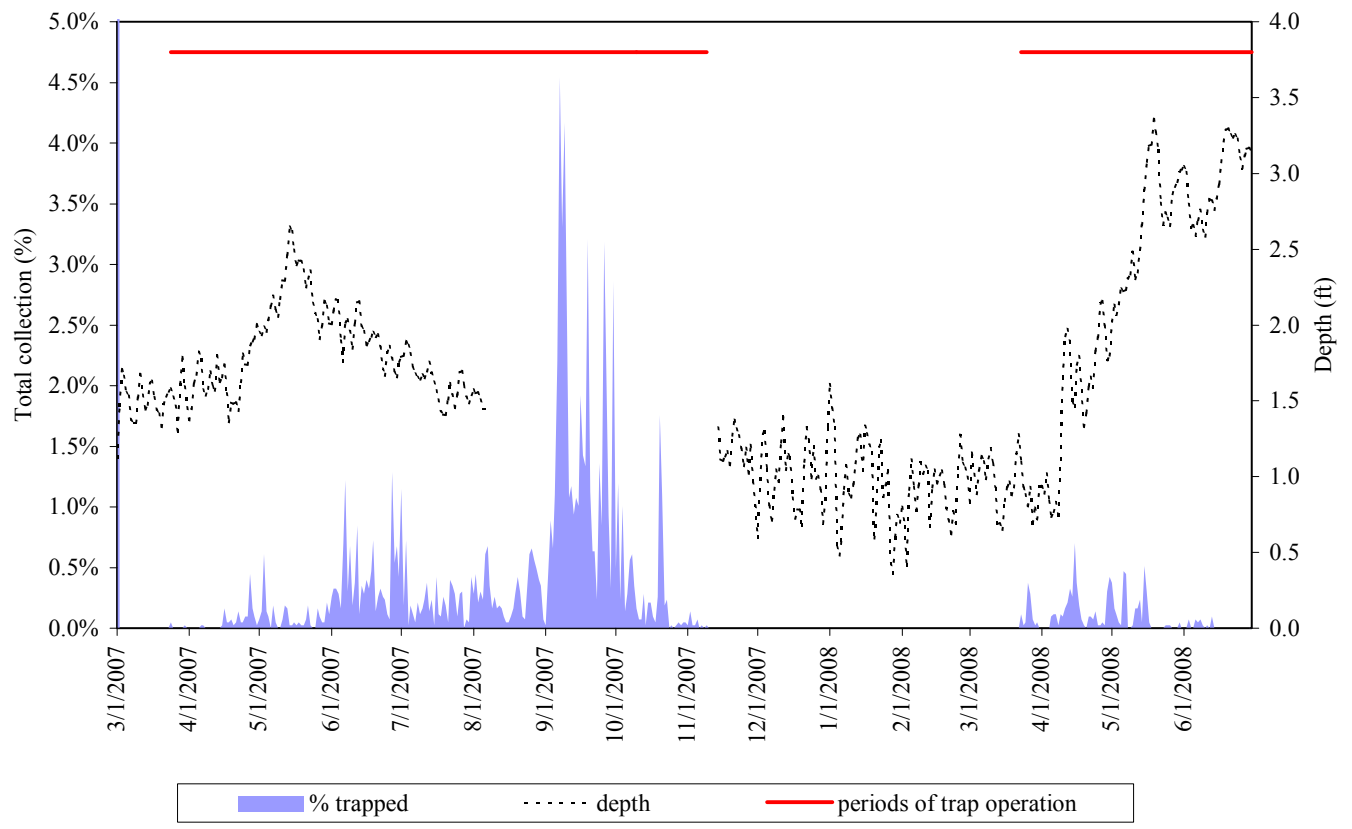

Appendix Figure 5. Daily passage of wild Chinook salmon fry, parr, and smolts at four migrant traps, expressed as percentages of total collected, and plotted against average daily depth collected near traps. Periods of trap operation are also shown. 
South Fork Salmon River Trap

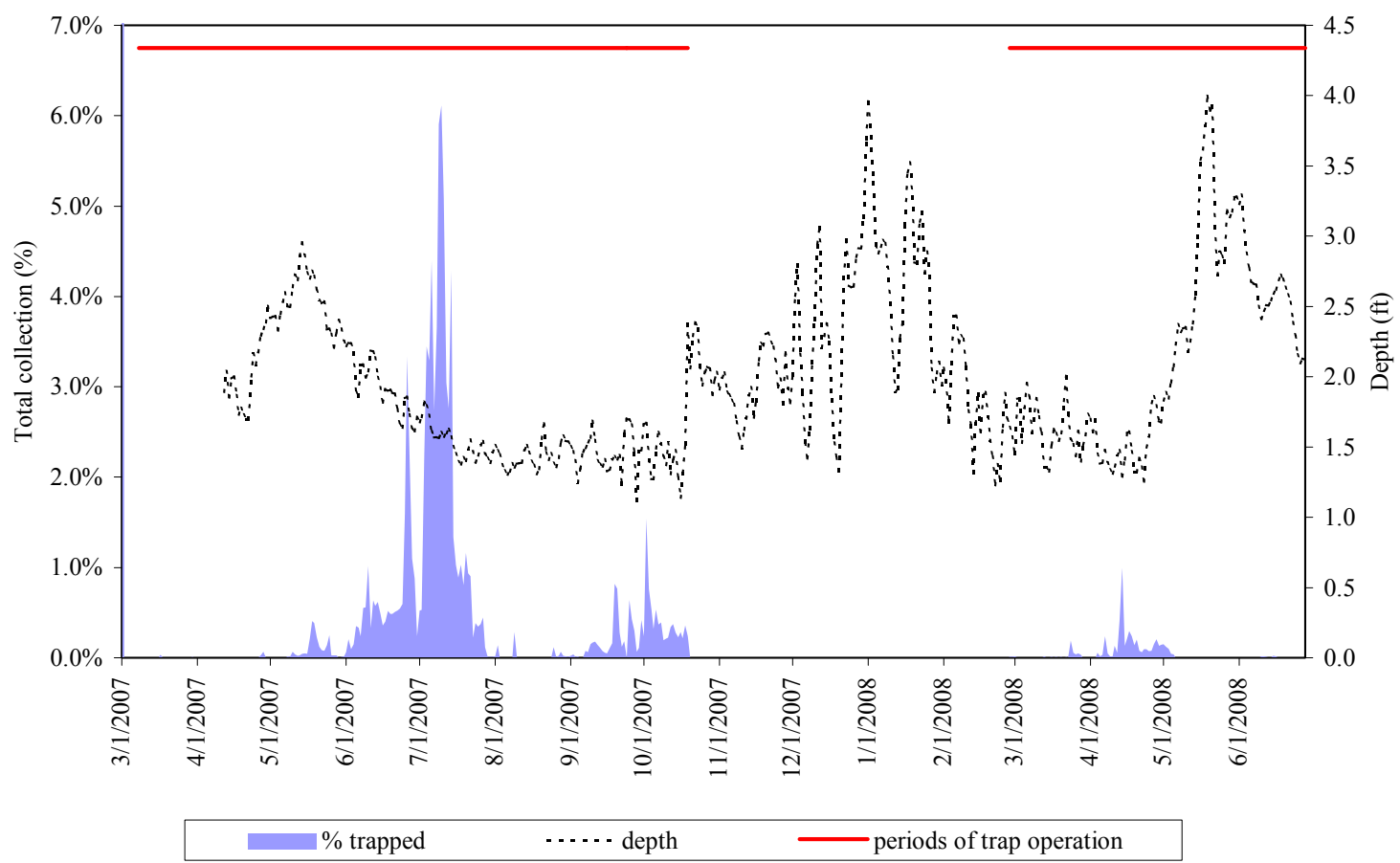

Secesh River Trap

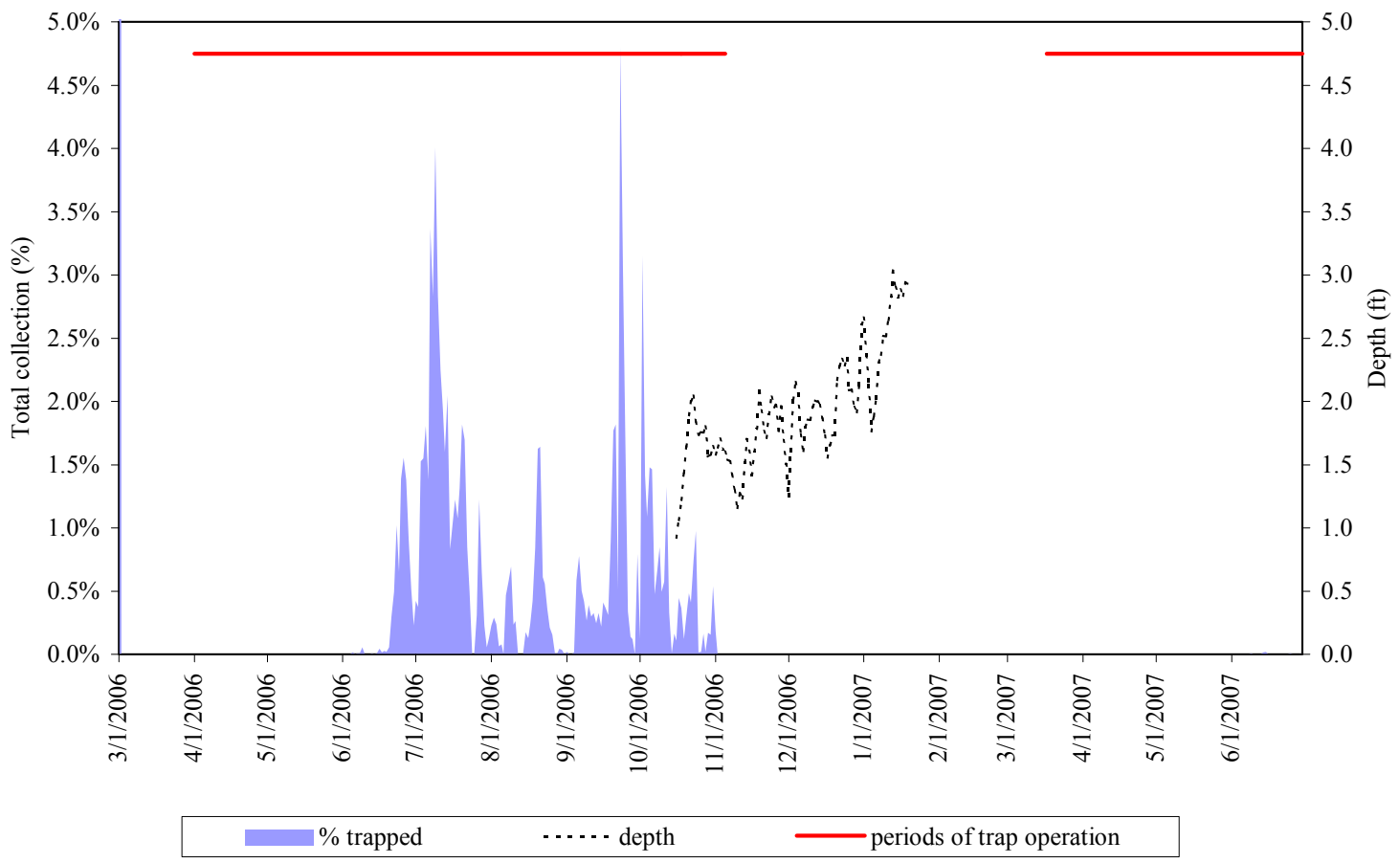

Appendix Figure 5. Continued. 

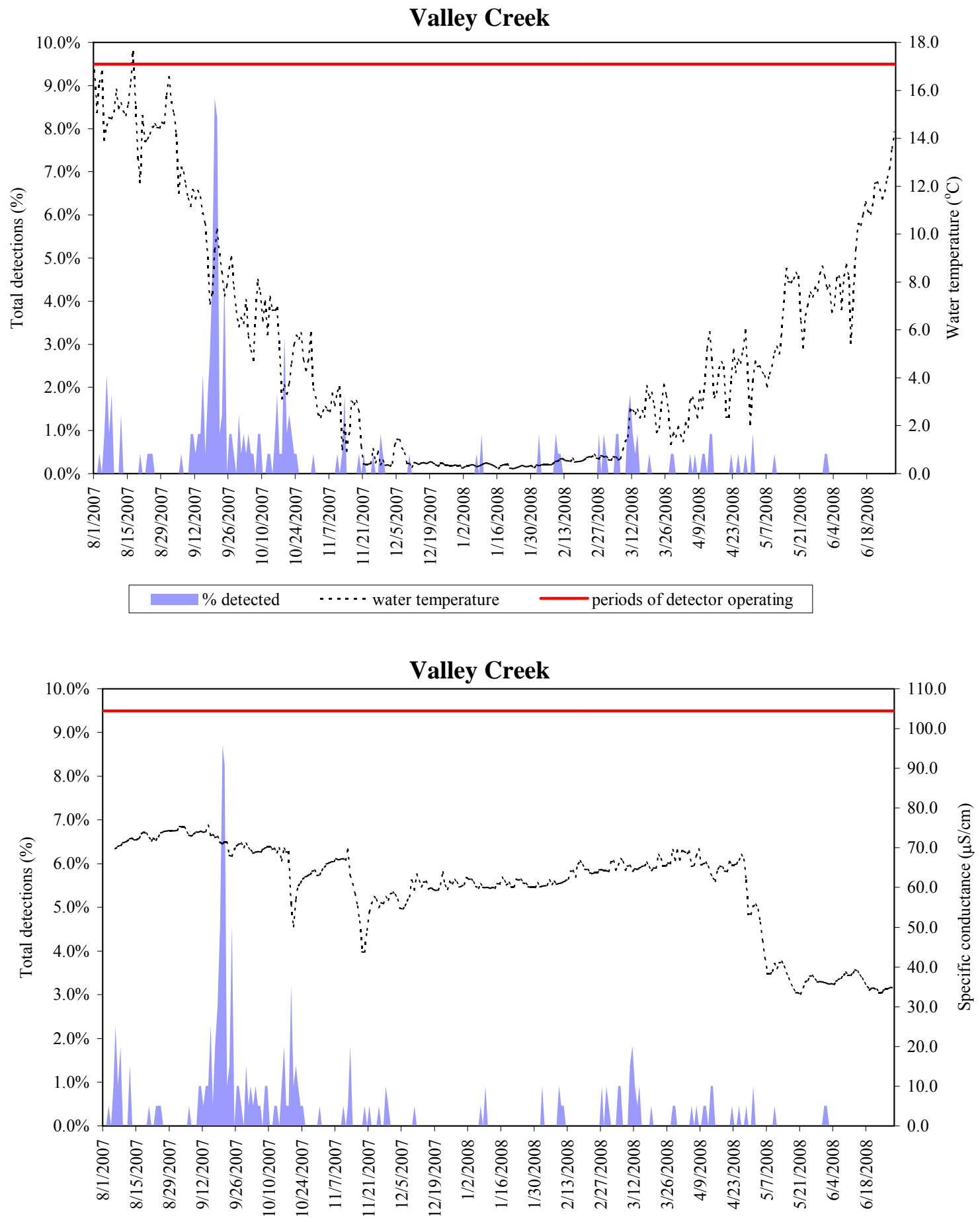

$\%$ detected $\quad \cdots .$. specific conductance — $\quad$ periods of detector operating

Appendix Figure 6. Combined daily PIT-tag detections of wild Chinook salmon parr at instream PIT-tag detectors in Valley Creek, expressed as percentages of total collected, and plotted against average daily aquatic conditions collected near the detectors. Periods of operation for the detectors are also shown. 

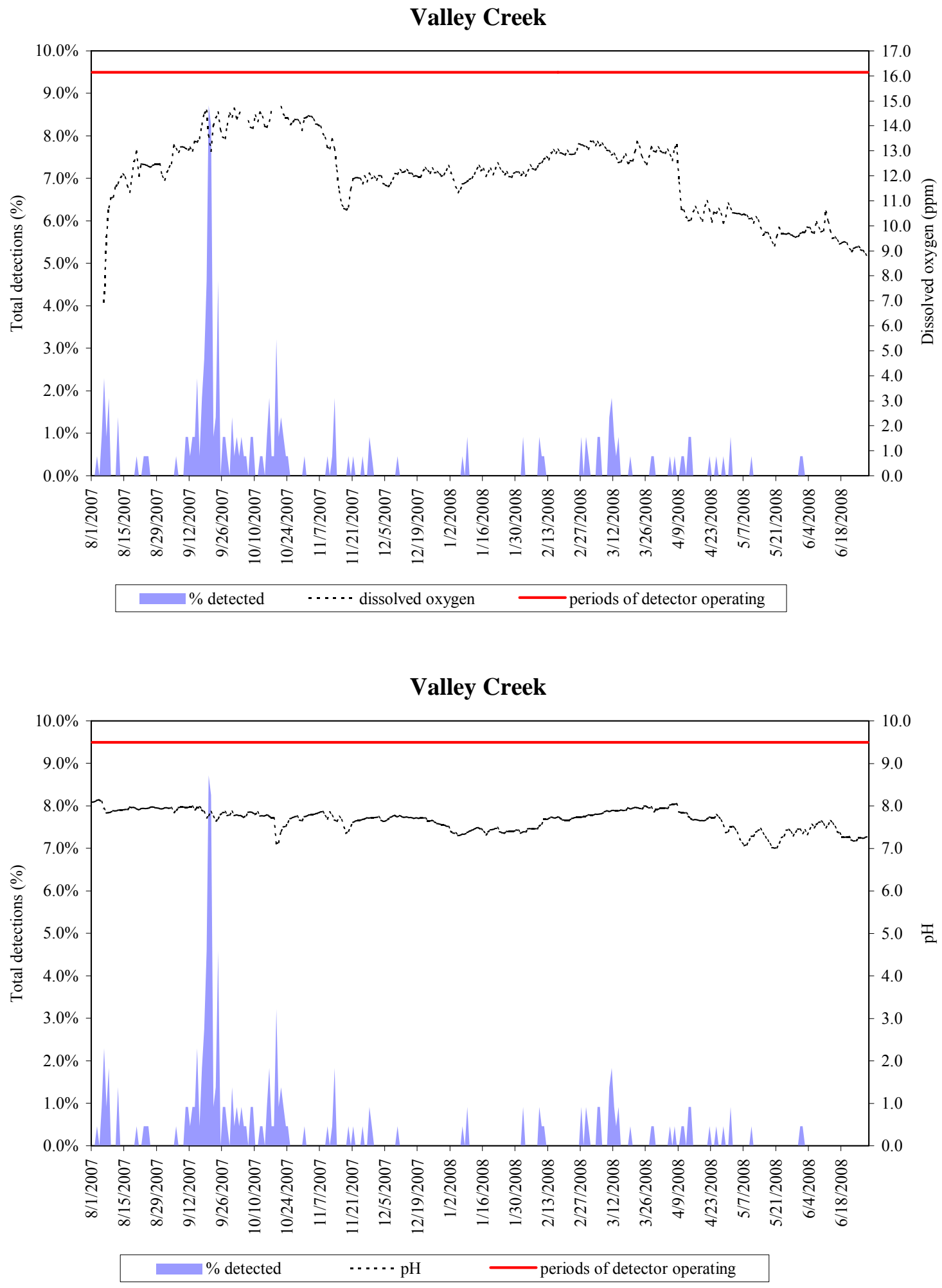

\section{Appendix Figure 6. Continued.}



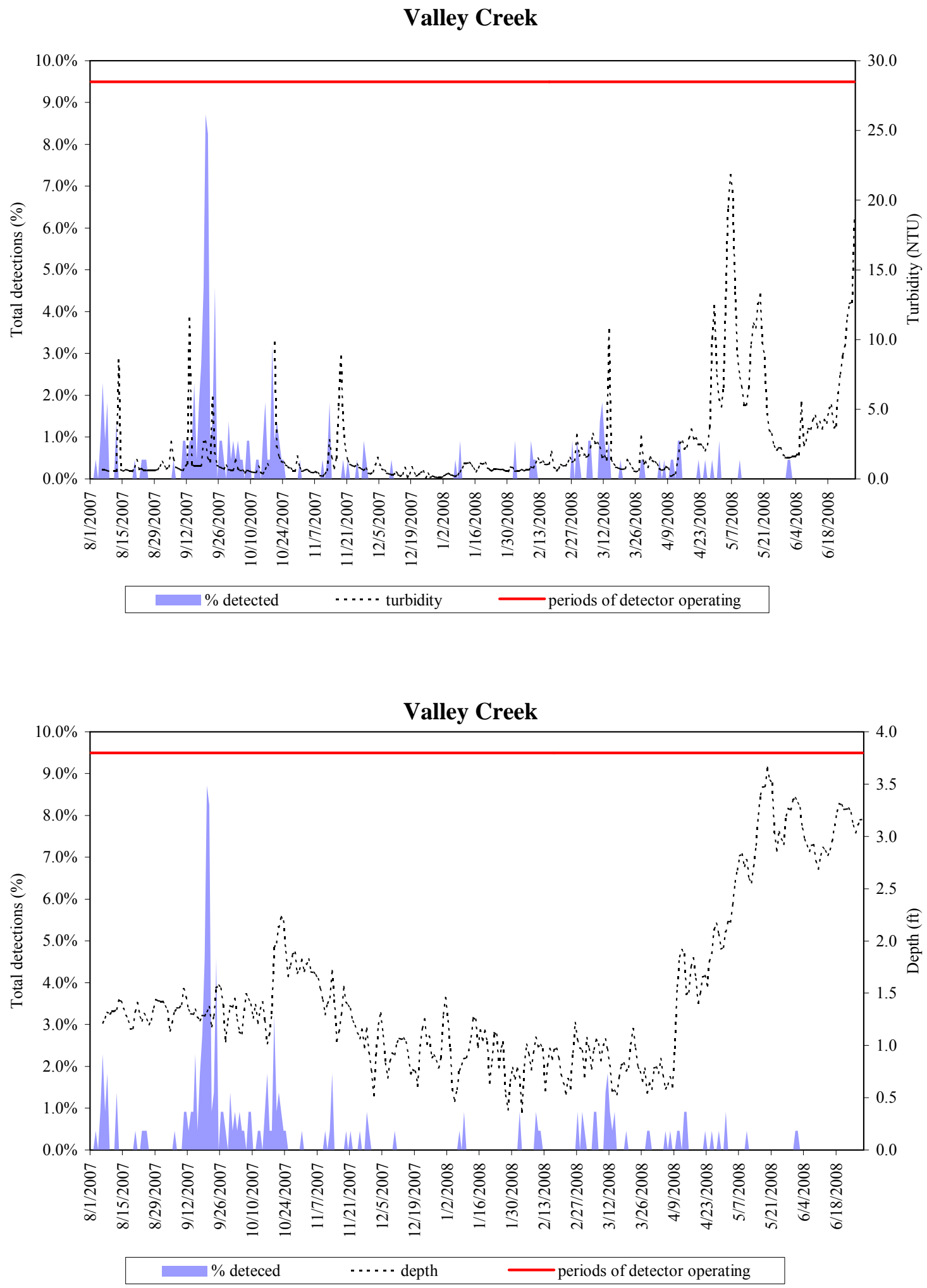

Appendix Figure 6. Continued. 